Glossary of Hausa Music and Its Social Contexts 



\section{Glossary of Hausa Music and Its Social Contexts}

David W. Ames

and

Anthony V. King

Northwestern University Press

Evanston 1971 
Open access edition funded by the National Endowment for the Humanities/Andrew W. Mellon Foundation Humanities Open Book Program.

Except where otherwise noted, this book is licensed under a Creative Commons Attribution-NonCommercial-NoDerivatives 4.0 International License. To view a copy of this license, visit http://creativecommons.org/licenses/by-nc-nd/4.0/

David W. Ames, Anthony V. King. A Glossary of Hausa Music and Its Social Contexts. Evanston, Ill.: Northwestern University Press, 1971.

For permissions beyond the scope of this license, visit http://www.nupress.northwestern.edu/

ISBN 978-0-8101-0361-0 (cloth)

ISBN 978-0-8101-3818-6 (paper)

ISBN 978-0-8101-3819-3 (ebook)

Original edition LCCN 76-164884 


\section{Contents}

INTRODUCTION vii

I. INSTRUMENTS AND THEIR PARTS 3

A. Instruments 3

1) Idiophones 4

2) Membranophones 12

3) Chordophones 40

4) Aerophones 47

B. Terms for Parts of Instruments 53

II. PROFESSIONAL PERFORMERS 61

A. Collective Terms 62

B. Classes of Performers 68

1) Masu ki'da ("drummers") 70

a. Idiophonists ("Drummers on idiophones") 70

b. Drummers 72

c. Lutenists ("Drummers of chordophones") 82

2) Masu busa ("blowers") 86

3) Mawak'a ("singers") 91

4) Marok'an baki ("acclamators") 94

5) 'Yan magana ("talkers") 96

C. Offices and titles of performers 97

$\begin{array}{ll}\text { III. PATRONS } & 105\end{array}$

$\begin{array}{lr}\text { IV. OCCASIONS } & 113\end{array}$ 
vi / CONTENTS

V. MUSIC PERFORMANCE

131

HAUSA INDEX

153

ENGLISH-HAUSA INDEX

165

ILLUS TRAT IONS

185 


\section{Introduction}

The richness, variety and complexity of the cultures of the Hausa city-states are illustrated in microcosm in this work, in which over one-hundred terms for musical instruments were collected for the kingdoms of Zaria and Katsina alone; and, no doubt, more will be identified in subsequent investigations. Complexity was encountered in other aspects of musical life, e.g., in the manifold classes of professional musicians, reflecting an extraordinary range of specialization in musical performance. As this suggests, the authors -- one an anthropologist and the other a musicologist -- have attempted to make this more than a technical glossary of musical instruments and sound production; in fact, it has grown to be a kind of shorthand ethnography of musical life, in which equal weight is given to the socio-cultural context of musical performance, as well.

\section{Scope}

Limiting the glossary to realistic proportions involves the problem of definition of the geographical, cultural and linguistic context for data collection. The Hausa language is spoken by more persons in sub-Saharan Africa than any other African language, and, obviously, the geographical distribution of its speakers is not nec- 
viii

essarily coterminous with the bearers of what might be loosely termed Hausa culture. Hausa recognition of a cultural dichotomy between the Hausa bakwai ("Hausa Seven," i.e., the seven authentic Hausa states) and the banza bakwai ("Worthless Seven," i.e., the seven impostor states) could serve as a valid basis for the limitation of data collection were it currently possible to define the boundaries of those states most popularly described as the Hausa bakwai; unfortunately, the nineteenth century jihad of Usuman 'Dan Fodiyo effected not only a change of socia1 organization within the traditional geographic boundaries of the Hausa bakwai, but it also effected the removal of considerable population elements of these $\mathrm{Ha}$ 'be (original Hausa) states to new geographical areas and the development of new cultural contexts.

We are thus forced either to attempt coverage of the whole of present-day Hausaland (involving extremely invidious cultural distinctions and an unrealistically large collection area) or to attempt an arbitrary selection of area or areas. Assuming this latter course to be the more practicable, it would then be advisable to choose areas coterminous with, and showing the closest social and cultural derivation from, the pre-jihad states. We are thus left with the present-day emirates of Kano, Katsina, Zaria, and Daura.

For this work, the authors have focused on two of 
these administrative and cultural areas, Katsina and Zaria, not because they are more important than the others but simply because most of the authors' field work was done there. (Note: Ames carried out an anthropological study of the status and role of Hausa musicians in Zaria in 1963-64 and King carried out his ethno-musicological investigations in Katsina in 1963-65 and in 1968.) Data from other areas are occasionally included if they are historically noteworthy, e.g., in the case of the royal

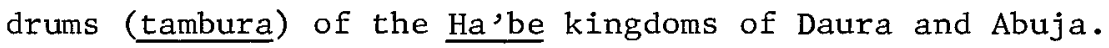
Not surprisingly, we found that the Hausa had no equivalents for some Western definitions, and vice versa. For example, the Hausa do not have a popular term for "music". Use of the term musika (? Arabic derivation) is confined to an extremely limited number of malamai (sing., malan; a Koranic scholar). Terms such as bushe-bushe (sing., busa; blowing), ka'de-ka'de (sing., ki'da; beating, shaking, plucking, or bowing), and wak'e-wak'e (sing., wak'a; singing), although describing the various methods of producing music, refer basically to performance technique rather than to the actual organization of sonorities. Similarly derived nouns of agent, e.g., mabusa (sing., mabushi), maka'da (sing., maka'di), and mawak'a (sing., mawak'i), refer to the performer's instrument in distinguishing between classes of musicians. The nearest equivalent to a popular generic term for "music" is rok'o 
(begging), but this term neither covers all organization of sonorities (e.g., it does not include amateur musicmaking) nor strictly excludes non-musical activities; it is, in effect, a reflection of social attitudes towards the musician rather than towards his product.

Account will be taken in this work not only of words referring to actual organizations of sonorities, but also of those referring to the social and ideational contexts and contents of such organizations. We have unavoidably resorted to the use of some Western categories for section headings; however, whenever possible, we have used Hausa categories to illustrate their cognitive system, as in the case of major classes of performers and generic terms for certain classes of instruments -- for example, ganga, a large class of double membrane drums.

Finally, it should be stressed that we do not hold this to be a definitive work. Indeed it is only a beginning or a statement of how far we have progressed with our study in this largely uncharted area.

\section{Presentation of Material}

The glossary is a Hausa-English collection, i.e., terms will be listed alphabetically under their Hausa form. Although this is the only practicable way to present such material, difficulties of use for non-Hausa speakers can be overcome with the help of the English- 
Hausa Index and the alphabetized index of Hausa terms. The reader is also advised to consult the introduction of each section for definitions and explanations of the numerical and letter indices.

Where understanding of the meaning of a term can be supplemented by demonstration of its use within the language, we have done so, and especially where the use of a term is an accepted form of expression (e.g., proverb, riddle, praise, etc.), throwing light on its social value. Where a term applies to some aspect of the organization of sonorities, examples will be scientifically described as far as possible.

\section{Orthography}

The standard orthography as used by the Gaskiya Corporation (printers to the Government of Northern Nigeria) is utilized as far as possible, with the following exceptions which are due to the printing process used in this work: the implosive voiced consonants will be written ' $b$ and ' $d$ and the plosive with a glottal stop (ejective) will be written $k$ ' as in G.P. Bargery's Hausa-English Dictionary (Oxford University Press, 1957). Although Hausa speakers have no difficulty with the Gaskiya Corporation orthography, non-Hausa speakers may wish to consult R.C. Abraham's Dictionary of the Hausa Language (University of London Press, 1962) for additional phonemic information. 
xii

Acknowledgements

Ames' research was assisted by grants awarded by the Joint Committee on African Studies of the Social Science Research Council and the American Council of Learned Societies and the Faculty Research Committee of San Francisco State College. King's field research was carried out while at the University of Ibadan on an appointment financed by a grant from the Ford Foundation of America to that institution, and in 1968 a second period of research was assisted by a grant from the Nuffield Foundation and the Central Research Fund of the University of London. The authors are especially indebted to Barbara Ames for spending many many hours preparing and editing the manuscript for this work.

The authors also wish to express their gratitude to the following persons and institutions for assisting them at various stages of their work: Alhaji Muhammadu Aminu, Emir of Zaria; Alhaji Sir Usuman Nagogo, C.N.Q., Emir of Katsina; the late Alhaji Muhammadu Sanusi, Waziri of Zaria; Alhaji Hasan Rafindadi, Sarkin Yak'i of Katsina; Malan Ibrahim Bagudu, Madauci of Zaria; Malan Muhammadu Bello; Malan Kontagora Salisu Ahmed; Malan Salisu

Kontagora; Malan Aminu Yero; Malan Isaac Umar; Malan Dauda Bagari; Malan Mohammed 'Danbala; Malan Bello Daura; Malan Rashid Ibrahim; Malan Kabir M. Galadanci; Malan Abbas Meslin; Malan Ibrahim Mukoshey; David W. Arnott; 
M. Hiskett; A.H.M. Kirk-Greene; Alan Merriam; J.P.S.

Montagu; M.G. Smith; the Institute of African Studies of Ibadan University; and the Institute of Administration of Ahmadu Bello University. 

Glossary of Hausa Music and Its Social Contexts 



\section{Instruments and Their Parts}

\section{A. INSTRUMENTS}

\section{Notes on Numerical and Letter Indices}

In the lists of instruments that follow --

Numerical indices in the right-hand margin are those of the Sachs-Hornbostel Classification; supplementary letter indices thereunder are used as follows:

$$
\begin{aligned}
& \text { o. - performer with official status; } \\
& \text { no. - performer without official status; } \\
& \text { p. - performer of professional status; } \\
& \text { np. - performer of non-professional status. }
\end{aligned}
$$

Information, where available, is presented in the following order:

1. General physical description and average dimensions where critical.

2. Terms for parts of the instrument and materials of construction.

3. Performance technique.

4. Ensemble combinations.

5. Social usage.

6. References in oral "literature" indicative of social values attaching to an instrument, its performer, or its performance, such references being drawn from kirari (traditional identificatory texts, often of an epithetical form) and karin magana (proverbial sayings). 
1) Idiophones

acikoko m.s.

112.13 no.np.

1. Pair of globular seed-pods partially filled with small stones, seeds, or other materials, and joined together by a short length of string and used as a rattle.

3. One pod is held in the palm of the hand and the other swung so that the string loops the hand and the second "free" pod strikes the first periodically.

4. Used in the accompaniment of song.

5. Used by young people of either sex for informal music-making.

agidigo m.s. (d.f. Yoruba, agidigbo)

$=$ iita m.s. (d.f. English, guitar) no.p.

1. Plucked idiophone constructed from a number of metal lamellae mounted on a wooden box-resonator.

3. Positioned on lap or suspended from neck in a horizontal position at waist level, so that the lamellae may be plucked with the fingers of either hand.

4. Used solo or in combination with kalangu, 'dan kar'bi and kuntuku in the accompaniment of song.

5. Used by musicians known as karen gusau for entertainment songs (wak'ar nasha'di) or, prior to January, 1966, for political songs (wak'ar siyasa).

bambaro m.s. no.np.

1. Iron Jew's (jaw's) harp of local manufacture.

3. Held by the left hand between the open 1 ips and teeth of the mouth, the lamella being plucked either towards or away from the face by the player's right hand; simultaneous tongue and glottal movement 
effect harmonic alterations, thus permitting the imitation of the syllable tones and vowel qualities of an underlying language text.

4. Used as a solo instrument.

5. Used by young people of either sex for informal music-making.

barancaki m.s. (pl. barancakai)

112.13

= barankaci m.s. (p1. barankatai)

no.np.

1. Long flatish dried seed pod of the barancaki plant, used as a hand-held rattle.

3. Held at its end in the right hand and beaten against the open palm of the left hand.

4. Used solo or in combination with other barancakai in the accompaniment of song.

5. Used by young people of either sex for informal music-making.

caccakai $\mathrm{p} 1 .=$ akacau $\mathrm{p} 1$.

akayau $\mathrm{pl}$. = k'oroso $^{\prime} \mathrm{p}$. no.np.

1. Iron ankle rattle.

3. Tied to dancer's ankle or ankles and sounded by leg movements in dance.

5. Worn by men in such dances as rawan Gane.

caki m.s. = buta f.s. = duma f.s.

$=$ galura f.s. = garura f.s. no.p.

= gora f.s. = gyan'dama f.s.

1. Hand-held rattle from a suitable container partially filled with small stones, seeds or other suitable objects. Strictly speaking, the name of the instrument derives from the nature of the container (see under 2 below), the term caki being generic for any 
instrument of this class.

2. (i) buta f.s.: a bottle-shaped gourd or tin container used for rattle body.

(ii) duma f.s.: the generic name for any one of a number of differently shaped gourds, in this case the name for any bottle-shaped gourd used for the rattle body.

(iii) galura f.s. = garura f.s.: a bottle-shaped gourd, used for rattle body.

(iv) gora f.s.: a bottle-shaped gourd used for rattle body.

(v) gyan'dama f.s.: a bottle-shaped gourd used for rattle body.

3. Held in the right hand and shaken and beaten against the open palm of the left hand.

4. Used either solo to accompany song or speech, solo or with one or more other caki to accompany garaya, komo or molo, or with garaya, komo or molo in the joint accompaniment of song.

5. Used solo to accompany song or speech by musicians such as 'yan garura; for ensemble combinations with other instruments, see garaya, komo and molo.

cakansami m.s. (p1. cakansamai)

= cikansami m.s. (p1. cikansamai) no.np.

1. Ankle rattle made from woven palm leaves and consisting of a number of small pouches partially filled with small stones, seeds, or other suitable objects.

3. Tied to dancer's ankle or ankles and sounded by leg movements in dance.

4. Used in dancing and singing to kwairama, gangar noma and kazagi.

5. Worn by young men and boys in such dances as rawan Gane. 
kacikaura f.s. = kacakaura f.s. 112.112

= kacaura f.s. = cakaura f.s. no.p.

$=$ lalajo $\mathrm{m} . \mathrm{s}$.

1. Sistrum made from a number of gourd discs strung on a thin straight stick, or from a number of tin discs strung on a short length of straight wire.

3. The ends of the stick or wire held in both hands and the whole shaken from side to side periodically.

4. Used solo or with one or more other kacikaura in the accompaniment of song.

5. Used by musicians known as 'yan kacikaura.

kasam'bara f.s. = sam'bara f.s.

= sham'bara f.s. no.p.

1. A length of guinea-corn stalk with a node at one end, shredded lengthwise from the latter to the open end to form a brush-1ike instrument.

3. Held between the palms of the hands and rotated by the rubbing motion of the latter.

4. Used on its own or with one or more other kasam'bara in the accompaniment of garaya, or with garaya in the joint accompaniment of song.

5. Most frequently found in the performance of music for bori.

kuge m.s.

1. Pair of clapperless iron, bronze or silver bells, joined at their apexes to the opposite sides of a common handle so that the larger and lower-pitched bell lies slightly further from the end of the handle than the other.

3. Held by the 1eft hand in an upright position at about shoulder level with the larger bell on the player's right; beaten on either bell with the pointed end of a duiker horn, the two pitch levels 


\section{$8 /$ GLOSSARY OF HAUSA MUSIC}

obtainable (at an interval of approx. 220 cents) used in the realization of the speech tones of an organizing language text (take).

4. Used solo for proclamations, such as the announcement of war, or in combination with kakakai (kakaki) and gangar fada (ganga) in the performance of take.

5. Ownership vested in the office of Emir or in that of one of his most senior officials (in Katsina, K'aura; in Zaria, Madaki or Galadima), for whom it is traditionally beaten. See masu kuge, marok'an Sarki, sarakuna, and marok'an sarakuna.

6.a. Kirarin K'auran Katsina (kirari for $\mathrm{K}^{\prime}$ aura of Katsina):

Goje a kira ka da kuge

"Goje (the usua1 epithet for K'aura), you are summoned with kuge!"

b. Kirarin Madakin Zazzau (Zaria):

Mai kugen tama mai kugen azurfa "Owner of the iron kuge, owner of the silver kuge"

k'warya f.s. (pl. k'ore)

111.24 no.p.

1. Hemispherical shell of a dried half-gourd, the various sizes encountered being related to their performance usages (see under 3 below).

3. The various sizes and usages and, in some cases, more specific terms for $\mathrm{k}^{\text {'warya }}$ are:

3.1. k'warya f.s.: a small gourd inverted against the chest and beaten with the fingers of both hands, with or without rings thereon; used by men or women in the accompaniment of song, either singly or with one or more other $k$ 'ore.

3.2. k'waryar kukuma f.s. ("the k'warya for kukuma"): similar to 3.1 above, but may alternatively be beaten with a pair of sticks; used by men or women in the accompaniment of kukuma, or with kukuma in the joint accompaniment of song.

3.3. k'warya f.s.: a medium or large gourd inverted on the ground and beaten with the fingers of both hands, with or without rings thereon; used by 
women in the accompaniment of song (ki'dan amada, wak'ar bori) either singly or with one or more other $k^{\prime}$ ore.

3.4. k'waryar goge f.s. ("the k'warya for goge"): a large gourd inverted on the ground and beaten with a pair of sticks; used by men in the accompaniment of goge or with goge in the joint accompaniment of song.

3.5. k'waryar ki'dan ruwa f.s. ("the k'warya for beating on water"): the term for a member of a set of three half-gourds used by women in the accompaniment of song (ki'dan amada, wak'ar kishiya), the specific instruments being:

3.5.1. masakin ka'dawa m.s. ("the large gourd for beating") = ganga, m. or f.s. = masakin amada m.s. ("the large gourd for amada music"): a large gourd inverted on a blanket folded on the ground, and beaten with the fingers of both hands, with or without rings thereon.

3.5.2. tulluwa f.s. = tilli m.s.: a small gourd inverted and floated in a bowl of water and beaten with a small stick.

3.5.3. kazagin amada m.s. ("the kazagi for amada music") $^{\prime \prime}$ kazagi m.s.: a smal1 gourd inverted on the ground and beaten with a pair of sticks.

ruwan gatari m.s.

1. An iron axe-head.

3. Held in one hand and beaten against a hoe-blade (ruwan patenya) held in the other hand.

4. Used solo or with one or more other pairs of such instruments in the accompaniment of song and/or dancing.

5. Used by 'yan daji during tashe. 
ruwan patenya m.s.

111.1

no.np.

1. See ruwan gatari.

sambani m.s.

111.14

no.np.

1. Two pairs of iron hand-clappers, each member of each pair being in the shape of a large langue du chat with small iron rings set into holes around the edge.

3. One pair is held in each hand with the second, third and fourth fingers supporting the upper clapper, and the thumb the lower; the clappers are separated and brought together periodically.

4. Used solo in the accompaniment of song.

5. Used by women for the accompaniment of songs, usually on a religious topic on occasions such as weddings or naming ceremonies, for malamai on the eve of Mauludu, for sarakuna on the two major festivals of Babbar Salla and K'aramar Salla and on eclipses of the sun.

shantu m.s. (p1. shantuna)

111.231 no.np./p.

1. The tubular shell of a long, narrow gourd, open at both ends; often decorated with patterns burned on, or cut into, the outside shell.

3. Held in the right hand and beaten in a variety of ways by the seated player, including the following:

3.1. Stamped with its lower end against the inside of the right thigh, or against the calf of the right leg.

3.2. Stamped with its upper end against the open palm of the left hand.

3.3. Tapped with its outer shell against the shin bone of the right leg. 
3.4. Tapped with the 1 ip of its lower end against the ground.

3.5. Tapped on its outer shell with rings on the fingers of the right or left hand.

4. Used singly or with one or more other shantuna in the statement of zambo, as in wak'ar kishiya, karin magana (proverbial sayings), etc., through the imitation of speech tone and quantity; used solo or with one or more other shantuna in the accompaniment of song.

5. Used by women for social comment (e.g. by a co-wife in criticism of her partners) or for informal musicmaking. Played by a male professional singer from Kano in accompaniment of song -- but this is an exceptional case.

tandu $\mathrm{m} . \mathrm{s} . \quad(\mathrm{p} 1 \cdot \underline{\text { tanduna }})$

111.24 no.p.

1. A narrow-necked leather flask.

2.a. kan tandu m.s.: the base of the flask.

3. Held in a near-horizontal position on the left side of the body, with the base to the front, and beaten with a (right) hand-held stick and the fingers of the left hand, with or without rings thereon. Also may be beaten with hands only.

4. Used solo or with one or more other tanduna and drums in the accompaniment of humorous songs.

5. Used by a male entertainer ('yan tandu) while dancing and in the accompaniment of song.

turmi m.s. (p1. turame)

1. Large wooden mortar of the kind used for pounding cereals.

2.a. ta'barya f.s. (p1. ta'bare): pestle.

3. Rhythmic pounding of foodstuffs performed by up to three women using one pestle each. Extra percussive 


\section{2 / GLOSSARY OF HAUSA MUSIC}

effects are produced by the pestle's being struck against the side of the turmi on the upstroke, followed by throwing the pestle upwards, clapping the freed hands, and catching the pestle for the downstroke.

4. Pounding with up to three pestles and often used as an accompaniment to song.

5. Used musically on such occasions as lugude.

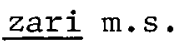

111.1 no.p.

1. Pair of iron rings.

3. Held one in each hand and beaten together.

4. Used solo or with one or more other zari in the accompaniment of song.

zunguru m.s. (p1. zungura)

111.231 no.p.

1. The tubular shell of a long, narrow gourd, larger than shantu, with one end closed and with small iron rings fitted around the rim of the open end.

3. Held in the hands and shaken and stamped on the ground.

4. Used solo or with one or more other zungura in the accompaniment of song.

5. Used by men and women for performances such as ki'dan malamai.

2) Membranophones

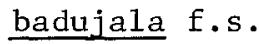

211.212 .1 no.np.

1. Imported military side-drum. 
3. Normal band technique.

4. Normal band combinations.

5. Normal band usage.

bandiri m.s.

1. Set of two or more drums, comprising the following:

1.1. Single-membrane circular frame-drum, with or without circular metal jingles.

1.2. Single-membrane bowl-shaped drum.

3.1. Frame drum held at the edge by the left hand, with the fingers positioned to mute the membrane, and beaten with the fingers of the right hand.

3.2. Bow1-shaped drum placed vertically between the folded legs and beaten with the fingers of either hand.

4. Used individually or as a set in the accompaniment or in the recitation of zikiri.

5. Used by some members of the K'adiriyya sect in the accompaniment of zikiri. Its comparatively recent introduction into the religious worship of this sect in Nigeria is attributed to Alhaji Nasiru Kabara, present-day head of the K'adiriyya; justification for its use in worship is claimed from the behaviour of Sidi Abdulkadiri, grandson of the Prophet, who performed zikiri to the accompaniment of handclapping.

banga $\mathrm{m}$. or f.s. (pl. banguna)

1. Sma11 single-membrane bowl-shaped drum with or without a layer of wax on the membrane centre.

2.a. awara f.s.: iron lacing-ring around the base of the body.

b. banga m. or f.s.: wooden body-she11, carved from alilliba, katsari, or k'irya trees. 
c. fata f.s.: membrane from gazelle or duiker skins.

d. kafar zuba mai f.s.: hole in side of body-shell for pouring mixture of oil and spice therein.

e. kirinya f.s.: hide ring lapping the membrane.

f. k'ofar zuba mai f.s. = kafar zuba mai (supra).

g. 1iko m.s.: plug for kafar zuba mai (supra).

h. ma'dauki m.s.: cloth carrying-strap, attached to body of banga.

i. maratayi m.s. = ma'dauki (supra).

j. nake m.s.: wax layer on membrane centre.

k. nike m.s. = nake (supra) .

1. rici m.s.: membrane lacing-thongs attached at their lower end to awara (supra).

m. rigar banga f.s. ("the gown of banga") cloth bag completely covering the drum-body but leaving the membrane exposed.

3. Hung suspended from the left shoulder so that it lies at waist level in a near-vertical position slightly to the left of the body; the player, normally seated in a cross-legged position, strikes the membrane with the fingers of either hand, on or off the central wax layer.

4. Used with one or more other banguna in the accompaniment of song by the drummers themselves.

5. Used by musicians of officialdom in Zaria and Katsina in the accompaniment of songs of praise of their patron. See masu banga, Magajin Banga, marok'an Sarki, marok'an sarakuna.

'dan kar'bi m.s.

$211.242 .1-812$

o./no.p.

1. Double-membrane hourglass drum, similar to but smaller than kalangu, with which it is customarily combined. Length of body-shell - 9"'; diameter of ends - 5.75"; diameter of waist - 2.375". 
2. As for kalangu.

3. See kalangu.

4. See kalangu.

5. See kalangu.

duma m.s. (p1 . dumamai)

$2 \times 211.221 .2-852$

no.p.

1. Set of two single-membrane barrel-shaped drums with closed ends, comprising:

1.1. duma m.s.: large gourd-bodied drum with two iron jingles attached. Length of body-shell - 26.5"; diameter of open end - 10".

1.2. talle m.s.: slightly smaller gourd-bodied drum with one iron jingle attached. Length of bodyshe11 - 25"; diameter of open end - 8".

2. Both instruments:

a. duma m.s.: gourd body-shell.

b. fata f.s.: membrane from goat's skin.

3. Performance technique derives to some extent from social usage, the two main methods of beating duma being:

3.1. The drums stand vertically on the ground supported by the knees of the seated player, with duma on the right-hand side and talle on the left; duma is beaten with a (right) hand-held stick and talle either with the same stick or with the fingers of the left hand.

3.2. Of the two drums, duma alone may be carried suspended from the left shoulder in a near-horizontal position under the left arm, with the membrane to the front; in this position it is beaten either with the right-hand stick or with the fingers of the left hand.

4. Used as a set in combination with kurya and kazagi for the accompaniment of song and/or dancing, the performance technique being as in 3.1 above. In addition duma may be used alone in combination with 


\section{$16 /$ GLOSSARY OF HAUSA MUSIC}

kurya and kazagi for the accompaniment of processional songs and/or dancing, the performance technique being as in 3.2 above.

5. Used by men (masu duma) at aure (marriage ceremonies, including the processional escorting of the bride), suna (naming ceremonies), and on festival days such as Babbar Salla and $\underline{\mathrm{K} \text { 'aramar Salla. }}$.

6.a. kirarin duma:

An ce gangana na duma ce to kowane ne a duma aka wanke shi

"Though it is said my drum is only made of gourd, whoever a man may be, he is first washed in such a gourd."

duman girke m.s.

$2 \times 211.221 .2-852$

no.p.

1. Set of two single-membrane barrel-shaped drums with closed ends, comprising:

1.1. duma m.s.: large wooden-bodied drum. Length of body-she11 - 27"; diameter of open end - $12 "$.

1.2. dumanya f.s.: slightly smaller wooden-bodied drum. Length of body-shell - 23.5"; diameter of open end - 11 ".

2. As for duma, from which they are said to derive, the main difference being in the wooden body-shells of duman girke carved from the k'irya tree.

3. Performance technique is largely the same as for duma, the main difference being that when the drums stand on the ground, they do so with their bases supported on cloth pads and without need of further support from the player's knees.

4. As for duma.

5. See masu duma. 
dundufa f.s. = dodara f.s.

= dumfa f.s. = $\overline{\text { totara }}$ f.s.

$=\underline{\text { tudara }}$ f.s.

no.p.

1. Set of two or three single-membrane cylindrical drums with closed ends. In Katsina, the set comprises $1.11,1.12$, and 1.13 below, in Zaria, 1.21 and 1.22:

1.11. uwar gida f.s. ("the senior wife"): length of body-shel1 - 36"; diameter of open end - 10".

1.12. duma m.s.: 1ength of body-she11-35"; diameter of open end - 8".

1.13. magu'diya f.s. ("the ululator"): length of bodyshel1-33.5"; diameter of open end - 7.5".

1.21. dundufa f.s. = uwa f.s. ("the mother").

1.22. 'yar dundufa f.s. ("the daughter of dundufa").

2. Al1 instruments:

a. cinki m.s. = tsinke m.s.: large iron needle used in lacing on a new membrane, and normally kept attached to the side of magu'diya.

b. fata f.s. = fatar akwiya f.s. = fatar tayin dalo f.s.: membrane of goat's skin (fatar akwiya) or from the foetus of a newly-born calf fatar tayin dalo).

c. furya f.s. = kwango m.s.: wooden body-she11 carved from kirya, alulluba or kawo trees.

d. hurya f.s. = maka'di m.s.: beating stick from aduwa, geza or sabara trees.

e. ido m.s. = k'ofa f.s.: hole in the side of the body-she11 for pouring a mixture of oil and spice therein.

f. kirinya f.s.: hide-ring lapping the membrane.

g. man gya'da m.s.: ground-nut oil, poured with spices into the body-shell.

h. rik'i m.s.: leather or iron lacing-ring around the base of the body-shell. 
i. tambari m.s.: calf-skin covering closed end of body-she11.

j. toto m.s.: plug for hole in body-shell.

k. tsarkiya f.s.: membrane lacing-thongs of gazelle skin secured at their lower end to rik'i, above.

3. In Katsina, the three drums stand vertically on the ground in front of the standing performer, with duma on his left, magu'diya in the middle, and uwar gida on his right; uwar gida and magu'diya are beaten with the right-hand stick or the fingers of the left hand, duma with the fingers of the left hand alone. In Zaria, the two drums stand vertically on the ground in front of the seated performer with the dundufa on his left and the 'yar dundufa on his right; they are beaten with a (right) hand-held stick and the fingers of the left hand.

4. Used as a set with three kazagi and one kuntuku or as a set with three kuntuku in the accompaniment of song and/or dancing. In Zaria, used as a set with one or more kuntuku

5. In Katsina, used by men on such occasions as marriage ceremonies, naming ceremonies, and on festivals such as Babbar Salla and K'aramar Sa11a. In Zaria, used by 'yan dundufa, who drum for blacksmiths (mak'era), their traditional patrons.

6. kirarin dundufa:

Wanda bai san dundufa ba hak'ik'an ya san murya tata "He who doesn, $t$ actual 1 y know dundufa will certainly be familiar with its sound."

ganga m. or f.s. ( 1 l. ganguna)

$211 \cdot 212 \cdot 1-812$

$0 . / \mathrm{no} \cdot \mathrm{p}$.

1. A generic term for any double-membrane cylindrical snared-drum, the most commonly encountered varieties being:

1.1. gangar algaita m. or f.s. ("the ganga for algaita") = k'aramar ganga m. or f.s. ("the small ganga"): after kurya (below), the smallest drum of this genre. Length of body-she11 - 13"; diameter of body-shell - $9.5^{\prime \prime}$. 
1.2. gangar Caji m. or f.s. ("the ganga of Caji"): a drum of a size intermediate between that of gangar algaita and gangar fada (below).

1.3. gangar fada m. or f.s. ("the ganga of the palace") = gangar saraki m. or f.s. ("the ganga of the official"), second in size only to gangar noma (below). Length of body-she11 - 17.5"; diameter of body-she11 - $13^{\prime \prime}$.

1.4. gangar noma $\mathrm{m}$. or f.s. ("the ganga of farming") = baragada f.s. = fya'de m.s.: the largest drum of this genre. Length of body-she11 - 26"; diameter of body-she11 - $18^{\prime \prime}$.

1.5. kurya f.s.: the smallest drum of this genre. Length of body-she11 - 6.75"; diameter of bodyshel1 - 8.5".

1.6. kwairama f.s.: about the same size as gangar fada (above). It frequently has a body-she11 made from a large oil or paint drum.

2. A11 instruments:

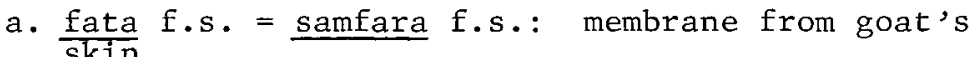

b. idan zakara m.s.: small seeds placed inside bodyshe11.

c. kango m.s. = kwango m.s. = ice m.s.: wooden bodyshell carved from alulluba or k'irya trees.

d. kirinya f.s.: hide-ring lapping the membrane.

e. ma'dauki m.s. = maratayi m.s.: cloth shoulderstrap attached to either end of the body-shell.

f. maka'di m.s. = hurya f.s.: hook-ended drumstick from root of gabaruwa tree.

g. murfi m.s. = mulhi m.s. = rigar ganga f.s.: cloth covering the body-shel1.

h. tambari m.s.: rear membrane.

i. tsarkiya f.s. = tsirkiya f.s.: lacing thongs of cow-hide joining the two membranes.

j. zaga f.s. = zaiga f.s.: snare on front membrane. 
k. ceba f.s.: iron jingle attached to upper bodyshell of gangar noma only.

3. A11 instruments are suspended from the left shoulder to 1 ie in a near-horizontal position under the left arm, with the snared membrane to the front (in the case of kurya the membranes are reversed, with the snared membrane to the rear). Either the snared membrane is beaten with the right-hand stick and the fingers of the left hand (this technique being termed hannun gaba), or the snared membrane is beaten with the right-hand stick only, then the rear membrane with the fingers of the left hand (this being termed hannun baya or taushi). Unlike the others, gangar noma is usual1y beaten with two drumsticks. The gangar noma is also laid on the ground with the rear end tilted up towards the performer's knee, so that the performer bends forward over the drum to strike the front membrane with a drumstick held in each hand, and at the same time, if required, he damps or mutes the rear membrane with his knee (the latter technique being termed taushi).

4. The ensemble combinations and social usages of the various drums of this genre are as follows:

4.1. gangar algaita: used in combination with one or more other gangunan algaita and one or more algaitai (algaita), or with kazagi by the musicians of an Emir, or of his senior officials, in the performance of take in honour of their patron or of his associates. See masu gangar algaita.

4.2. gangar Caji: used in combination with one or more other gangunan Caji, kazagi and kalangu in the accompaniment of popular song by non-official freelance musicians whose performances are in that style known as Caji.

4.3. gangar fada: used by the musicians of an Emir or of his senior officials in the performance of take in honour of their patron or of his associates. In Katsina, such performances under the head of the royal musicians, Sarkin Maka'da, normally involve the synchronic realization of one or more take on a group of gangunan fada, kakakai (kakaki) and farai, in combination with a vocal realization of a kirari by one or more of the drummers. In Zaria, the head of the royal musicians is the Sarkin Busa, and the above ensemble is extended to include one or more k'aho. See sarakuna, marok'an Sarki, marok'an sarakuna. 
4.4. gangar noma: used in combination with kazagi by a large class of professional but mainly non-official drummers called masu gangar noma, who beat the take and sing the praises (ki rari) of manoma, their principal and traditional patrons. See'yan hoto, wasan 'yan hoto, gardin kura, wasa da kura, gayya, kalankuwa, rawan Gane, Sarkin Gangar Noma and Sarkin Gangar Noman Zazzau.

4.5. kurya: used by the musicians of an official of an Emir. It is also used by non-official freelance musicians.

4.6. kwairama: used by professional but non-official musicians called masu kwairama, for such entertainments of the youth (samari and 'yan mata) as kokawa, a sha k'afa, rawan Gane, rawan , yan mata, kai gara and kalankuwa. Drummed solo or in combination with other kwairama and one or more kazagi.

6. As might be expected, there are numerous references to ganga in oral literature, some of the most common being:

a. Riddle:

Abu na k'ara a dawa ba hanji -- ganga

"A thing that cries out in the forest and yet has no guts -- ganga."

Daga nesa na ji muryar k'awata -- ganga

"From the distance I hear the voice of my gir1friend -- ganga."

b. karin magana:

Idan ka ji ganga na amo (ta cika zak'i) za ta

fashe ne

"When you hear ganga resounding afar (or filled with sweetness) it is about to burst."

Sai an ci moriyar ganga sa'anan a ke yadda kwango "After extracting one's profit from ganga, one discards it in a deserted place."

Kai bakin ganga ne duk inda aka ta'ba zak'i "You are 1 ike a double membrane drum, either side beaten will sound sweet," i.e., reference to a two-faced person. 
Matsi ka sa ganga zak'i

"Tightening makes the ganga sound sweet," i.e., pressure makes difficult persons respond.

c. kirarin kurya:

Kurya, gangar mutuwa

"Kurya, drum of death!"

Kowa sha ki shina barin 'da nai

"Whoever hears you is in the act of leaving his son (to go to war)."

Ki'di kusa wasa nesa

"When its druming is near, play is far away."

gangar 'yan kama m. or f.s.

"the gangar of the "yan kama")

211.241 .1

no.p.

1. Single-membrane, snared hourglass drum of fixed pitch.

2.a. fata f.s. = fatar tayin dalo f.s.: membrane from the foetus of a newly born calf, or from the lungs of a cow.

b. kango m.s. = kwango m.s.: wooden body-shell carved from alulluba or $\mathrm{k}$ 'irya trees.

c. kungu m.s.: leather ring lapping the membrane, made from old membranes.

d. tsarkiya f.s. = tsirkiya f.s.: leather thongs securing membrane to a hide-ring around the middle of the body-shell.

e. $\underline{\text { zaga }}$ f.s. = zaiga f.s.: snare from a cow's vein.

3. Suspended from the left shoulder in a near-horizontal position under the left arm so that the membrane lies to the front, and beaten with the fingers of either hand.

4. Used solo or with other gangunan 'yan kama in the accompaniment of recitation and song.

5. Used by 'yan kama in the accompaniment of derisory or satirical songs, recitations and actions. 
jauje m.s. (p1. jawajawai)

1. Double membrane hourglass drum of variable pitch similar to but larger than kalangu. Length of bodyshe11 - 20"; diameter of ends - 9"; diameter of constricted waist - 4".

2.a. dagarya f.s.: hide-ring lapping either membrane.

b. 'dan kawo m.s.: seed of the kawo tree placed inside the body-shell.

c. hurya f.s.: hook-ended drumstick from the root of the gabaruwa tree.

3. Suspended from the left shoulder in a near-horizonta1 position between the left upper arm and chest with the beaten membrane to the front; the front membrane only is beaten, with the right-hand stick or the fingers of the left hand, pitch alterations being achieved by increasing or decreasing pressure on the tensioning thongs running the length of the body and joining the two membranes.

4. In combination with up to ten other jawajawai and one or more kolaye (kolo) in the performance of take and/or the accompaniment of song.

5. Used by the musicians of an Emir, or of his senior officials, in the performance of music in honour of their patron or his associates. While in Zaria jawajawai are owned by the Emir as well as by some of his district heads, in Katsina they are owned by Galadima, one of the four most senior district heads and not by the Emir.

6.a. kirarin jauje:

Jauje ki'dan mutuwa wanda ba ka taran da'di "Jauje, drum of death which you don't encounter with pleasure."

kalangu m.s. (p1. kalangai)

$211.242 .1-81$

$0 . \mathrm{no} / \mathrm{p}$.

1. A generic term for a group of double-membrane hourglass drums of variable pitch similar to but smaller than jauje and larger than kolo and 'dan kar'bi, the individual instruments being: 
1.1. ka1angu m.s.: the most commonly found drum of this group, smaller than kalangun Sarki (below) and larger than $k^{\prime}$ aramar kalangu (below). Length of body-shell - 14"; diameter of ends - 6.5"; diameter of constricted waist - 3".

1.2. kalangun Sarki m.s. ("the kalangu of the Emir"): similar to but larger than kalangu (above).

1.3. k'aramar kalangu m.s. ("the small kalangu"): similar to but smaller than kalangu (above) but larger than the 'dan kar'bi.

2. Al1 instruments:

a. icen kalangu m.s. = kango m.s. = kwango m.s.: wooden body-shell of kalangu, carved from kawo, kimba, k'irya, or marke trees.

b. kambu m.s. = kirinya f.s.: 1eather-covered lapping ring on membrane.

c. $\mathrm{k}^{\prime}$ angu m.s. = 'dauri m.s.: leather strap attached at one end to the waist of the body-shell and used for tying in the tensioning thongs when the drum is not in use.

d. maka'di m.s.: hook-ended beating stick from the root of the gabaruwa or sanya trees.

e. saisaya f.s.: hide lapping-ring sewn to membrane.

f. Samfara f.s.: membrane from young goat's skin.

g. tsarkiya f.s. = tsirkiya f.s.: lacing thongs of cow hide joining the two membranes.

h. tuke m.s.: fine thread of goat's skin used to sew saisaya to samfara.

i. 'ya'yan baba $\mathrm{pl}$. = 'yan'yan kalangu p1.: seeds of baba, kimba, or other plants placed inside bodysheli.

3. Suspended from the left shoulder and beaten like jauje. A kalangu drummer also frequently beats 'dan kar'bi at the same time, in which case he may either suspend the latter from his left shoulder so that it lies below kalangu, or more commonly when seated, place 'dan kar'bi across his left knee with the shoulder strap around and under his right knee or around the big toe of his left foot. In both of 
these latter cases the pitch of 'dan kar'bi is varied by increasing or decreasing the pull on the shoulder strap with the right knee or left big toe, such action being termed tillo.

4. Used solo, in combination with 'dan kar'bi, in combination 'dan kar'bi and kuntuku, also with jita, kurya, kuge, and kolo. Also in combination with goge and $\mathrm{k}^{\prime}$ warya; or with kukuma and $\mathrm{k}$ 'warya. The k'aramar kalangu is played in combination with gangar $\mathrm{Caji}$ and kazagi of $\mathrm{Caji}$ singers and also with the kazagi and tallabe of 'yan gambara. And in any or all of these combinations in the accompaniment of song and/or dancing.

5. The various social usages are as follows:

5.1. kalangu: used most often by a class of professional (usually non-official) musicians called masu kalangu in various kinds of drumming for butchers (mahauta), their traditional patrons, and for the dancing, singing, ceremonies, and games of the youth. For the latter the drummer beats the 'dan kar'bi together with the kalangu. It is also used for the accompaniment of freelance singers such as Alhaji Muhamman Shata. See masu kalangu, ki'dan mahauta, Sarkin Maka'da.

5.2. kalangun Sarki: In Zaria, and in some other Emirates, used solo or in combination with kolo or kuge by an official musician of the Emir (masu kalangun Sarki) for performance of music in his honour.

5.3. k'aramar kalangu: used by non-professional freelance musicians performing in market places, sometimes by non-professional musicians drumming for butchers, and by yaron Caji (yara) and 'yan gambara.

6.a. karin magana:

Matsi shi ka sa kalangu zak'i

"It's the squeezing makes kalangu sound sweet."

Wane bakin kalangu ne ko ina aka buga sai zak'i

"One is like the mouth of the kalangu, if you beat either side it will sound loud (sweet)."

(Note: gossipers are called "bakin kalangu" who "beat" here and "beat" there -- ka buga da nan, ku buga da nan.) 
Ana ruwa ya ci maka'di ku kuna kalangu ya jik'e "The river drowns the drummer and you are concerned about the kalangu getting wet."

Tun daga somomo inda ka somi duniya kalangu yake "The kalangu has been in existence since the beginning of the world."

Su wance 'yan baka, kura ta 'dauko kalangu "Those who are talkative are like a hyena who has seized a kalangu." (i.e., causing the seeds to "chatter.")

Kwaram kwatsam mai kalangu ya fa'da a rami

"SuddenTy there is a noise of falling objects, the mai kalangu fell into the hole."

Ba giringirin ba a yi mai kura ta 'dauki kalangu

"Not for the sound but for the meat the hyena seized the kalangu." (i.e., deeds, not words, are required.)

kazagi m.s. (p1. kazagai)

= kanzagi m.s. (p1. kanzagai)

$211.241 .1-812$

no.p.

1. Single-membrane snared hourglass drum of fixed pitch. Length of body-shell - 9"; diameter of ends

- 5.5"; diameter of constricted waist - 3.5".

2.a. kango m.s. = kwango m.s.: wooden body-shell carved from $k$ 'irya tree.

b. k'angu m.s.: 1eather strap attached at one end to the waist of the body-she11 and used for tying-in the tensioning thongs to give the drum a fixed pitch.

c. kirinya f.s.: leather covered lapping-ring around membrane.

d. maka'di m.s.: hook-ended drumstick (see also 'ya'yan kazagi, below).

e. tsarkiya f.s. = tsirkiya f.s.: lacing thongs of gazelle skin, attached at their lower end to turu (below).

f. turu m.s.: leather thong strung through holes bored around the edge of the open end of the body- 
she11, and used to secure tsarkiya (above) at their lower end.

g. 'ya'yan kazagi p1.: pair of beating thongs made from short lengths of wire wrapped in cloth or leather, or from strips of leather plaited and bound in cloth and finally covered with leather.

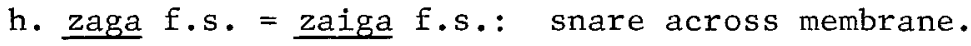

3. Either suspended from the player's neck so that it lies in a vertical position at waist level, in which case it is beaten with 'ya'yan kazagi (above), or suspended from the left shoulder so that it lies in a vertical position to one side, in which case it is beaten with one or two maka'di (above).

4. Combined in performance with dundufa, with duma and kurya, with duman girke, with gangar algaita, with gangar noma, with kwairama, or with tallabe, or with any or all of these combinations being in the accompaniment of song and/or dancing.

5. See dundufa, duma, duman girke, gangar algaita, gangar noma, kwairama, 'yan kazagi.

6.a. karin magana:

'Dan kazagi ya fi mai duma 'doki

"The performer on kazagi surpasses the performer on duma in eagerness," (i.e., "It is the lesser member of a partnership who is the keenest.")

b. Riddle:

Ranka bado kan gyeza -- kazagi

"The life of the water lily (the membrane) and the head of the gyeza twig (the snare) -- kazagi."

kolo m.s. (p1. kolaye)

211.242 .1 .812

o.p.

1. A double-membrane hourglass drum similar to jauje, with which it is normally combined, but smaller and of fixed pitch.

2. See jauje.

3. Held as is jauje, but with the tensioning thongs bound in to give a fixed pitch and normally beaten 
only with a stick. A kalangu is also played this way in combination with the kalangun Sarki and is similarly called kolo.

4. See jauje.

5. See jauje, masu jauje, marok'an sarakuna, marok'an Sarki.

kotso m.s. (pl. kotsanni)

$211.241 .1-81$

o.p.

1. Single-membrane snared hourglass drum of variable pitch. Length of body-shell - 36"; diameter of ends - 6"; diameter of constricted waist - 3".

2.a. ice m.s. = kango m.s. = kwango m.s.: wooden bodyshell carved from alulluba (= aliliiba) tree.

b. kirinya f.s.: leather lapping-ring around membrane.

c. k'ofar tsarkiya f.s.: holes drilled around edge of open end of body-shell.

d. mak'ogaro m.s.: open end of body-shell.

e. ma'dauki m.s. = maratayi m.s.: cloth shoulder strap attached to either end of the body-shell.

f. nake m.s. = nike m.s.: wax layer on membrane centre.

g. samfara f.s. = fatar akwiya f.s.: membrane from young goat's skin.

h. tsarkiya f.s. = tsirkiya f.s.: leather lacingthongs attached at their lower end to $\mathrm{k}$ 'ofar tsarkiya (above).

i. $\underline{\text { zaga f.s. }}$ zaiga f.s.: snare on membrane.

3. Suspended from the player's left shoulder so that it lies in a near-horizontal position between the left upper arm and the chest; beaten with the fingers of either hand, on or off the central layer of wax, further changes of pitch being effected by increasing or decreasing the pressure of the left upper arm on the tensioning thongs running the length of the body and securing the membrane at one end to the 
holes in the body-shell at the other.

4. Used in combination with one or more other kotsanni in the accompaniment of song.

5. Used by the musicians of an Emir, or of his senior officials for the accompaniment of songs in honour of their patron or his associates. Formerly kotso drummers accompanied the Emir's party into battle and on raiding expeditions. See Masu kotso, marok'an sarakuna, and marok'an sarki.

6.a. kirarin kotso:

In ka ji kotso kutsa dawa

"Should you hear kotso, melt away into the forest (for an Emir is approaching)."

Kotso mai murya goma

"Kotso, owner of ten voices."

kuntuku m.s. = kurkutu m.s.

$211.11-852$

$=$ kuttuku m.s. = kuntukuru m.s.

no.p.

1. Sing1e-membrane snared bow1-shaped drum. Length of body-she11 - 7"; diameter of open end - 7".

2.a. ice m.s. = kango m.s. = kwango m.s.: wooden bodyshe11 carved from kawo, k'irya or maje trees.

b. ido m.s.: hole in side of body-shell for pouring mixture of oil and spices therein.

c. k'angu m.s.: leather or cloth lapping-ring around membrane made from grass or broom fibres bound in leather or cloth; also leather belt around base of body to which lacing thongs are attached at their lower end, made from plaited thongs or wire bound in leather.

d. tsarkiya f.s. = tsirkiya f.s.: leather lacingthongs from goat skin.

e. 'yan sanduna p1.: pair of beating sticks, straight or slightly curved.

3. Suspended from the neck so that it lies in a vertical position at waist level, or so that it rests in the lap of a seated player, kuntuku is beaten with 
the pair of sticks held one in each hand in a rapid staccato-like style.

4. Used in combination with one or more kalangai (kalangu) and one 'dan kar'bi in the accompaniment of song and/or dancing. It is also used in accompaniment of dundufa in Zaria.

5. See kalangu, dundufa, masu kalangu, and 'yan dundufa.

6.a. karin magana:

Kuntuku ya fi ka1angu zak'i

"The kuntuku is louder (sweeter) than the kalangu.

kuru m.s. (p1. kuwaru)

211.241 .1 no.p.

1. Single-membrane snared hourglass drum of fixed pitch; length of body-shel1 - 26"; diameter of membrane end - 9"'; diameter of open end - 7"; diameter of constricted waist - $3.5^{\prime \prime}$.

3. Held suspended from the left shoulder in a horizontal position at waist level, kuru is beaten with the fingers of either hand on or off a wax layer at the centre of the membrane by the drummer who may be stationary or dancing.

4. Used in combination with up to ten other kuwaru in the accompaniment of song and/or dancing.

5. As for gangar noma.

tallabe m.s. = gambara f.s. no.p.

1. Double-membrane cylindrical drum. Length of bodyshell - 18"; diameter of ends - 9".

2. As for ganga with exception of the snare.

3. Held suspended from the neck and left shoulder so that it 1 ies in a horizontal position at waist level across the front of the body, it is beaten on the right-hand membrane with a right-hand stick, and on 
the other membrane with the fingers of the left hand.

4. Used in combination with kazagi in the accompaniment of recitation, song and/or dancing.

5. Used by such performers as 'yan gambara, na uwale, 'yan jarfa (tattooers) and masu wasa da kura.

ta11e m.s.

Terms used for two sorts of drums:

1.1. Single-membrane drum with a half-gourd body-shell.

1.2. Single-membrane circular frame drum like the Yoruba sakara.

3. Held at the edge by the left hand with the fingers positioned to mute the membrane, and beaten with a right-hand hooked stick.

5. Both used by men in Zaria (maka'dan 'yan tauri) for performances in honour of yan tauri. They are said to have used the kurya as well. Medicine vendors often beat talle to advertise their wares.

tambari m.s. (p1. tambura)

1. A generic term for a large single-membrane, bow1shaped drum, ownership of which is vested in the office of an Emir or equivalent authority.

1.1. In Zaria two pairs of large tambura called salosalo and 'yan 'dai-'dai and up to two kuntukun tambari are played in the 'dakin tambari (house of the tambari). The largest member of the set is termed giwa. The chiefs of the former vassal kingdoms of Kauru, Kajuru, and Lere -- now districts and sub-districts of Zaria Emirate -- also have tambura as part of their inherited regalia of office. Seven of the tambura of the Emir of Zaria and the Chief of Kauru ranged from 17 to 21 inches in height and 16 to 21 inches in membrane diameter. The kuntukun tambari are similarly constructed but smaller: about 11 inches in diameter 
and 11 inches in height. None of the tambura or kuntukun tambari of the Emir of Zaria are especially old.

1.2. In the emirate of Abuja, where the pre-Jihad rulers of Zaria are now in residence, the royal regalia includes: two lingarai with bronze bodyshells brought to Abuja from Zaria early in the 19 th century; and a newer tambari with a wooden body-shel1 like those of zaria today. The set are stored and played in the zauren tambari. Lingarai 非 1 has a membrane diameter of $10-1 / 2$ inches and a height of 8-1/2 inches; Lingarai $\#_{2}$ is 9 inches in diameter and 8-1/2 inches high. The tambari has a membrane diameter of 17-1/2 inches and a height of 18 inches.

In Katsina the following ten royal tambura are owned by the Emir:

1.3. Gwabron Tambari m.s. ("the unique tambari"): the most important tambura captured from the original Court of Katsina during the jihad of Shehu Usuman 'Dan Fodiyo, the drum has a bronze-cased body with a height of 9 " and a membrane diameter of $26^{\prime \prime}$.

1.33. Lingarai m.s.: like Gwabron Tambari, captured from the original court of Katsina during the jihad of 'Dan Fodiyo. Height of wooden body 20"; diameter of membrane - 15 ".

1.34. Unnamed: likewise captured during the jihad. Height of wooden body - 20"; diameter of membrane -17 ".

1.35. Gobir m.s.: captured in the 19th century from the Court of Gobir. Height of wooden body - 19"; diameter of membrane - $16^{\prime \prime}$.

1.36. Gamaruga m.s.: presented to the present Emir, Alhaji Sir Usuman Nagogo, on his accession by the Emir of Daura. Height of bronze-cased body 23"; diameter of membrane - $21 "$.

1.37. Unnamed: 1ike Gamaruga presented by the Emir of Daura.

1.38. Unnamed: presented to Alhaji Muhamman Dikko, father and predecessor of the present Emir, by the Emir of Azben. 
1.39. Unnamed: made to commemorate the Queen's visit in 1956.

1.40. Unnamed: 1ikewise made to commemorate the Queen's visit.

1.41. Unnamed: 1ikewise made to commemorate the Queen's visit.

2. A11 instruments:

a. akushi m.s. = akwashi m.s.: wooden body-shell carved from ka'danya or maje trees.

b. daro m.s.: bronze-cased wooden body-shell.

c. dorina f.s. = bulala f.s.: beating-thongs made from hippopotamus hide.

d. kayan yaji m.s.: oil and spice mixture poured into body through the hole in the side.

e. k'irgi m.s.: membrane from bull or cow-hide.

f. kirinya f.s. = zobe m.s.: iron lacing-ring around base of body-shell.

g. marfi m.s.: plug for hole in side of body-shell.

h. rami m.s.: hole in side of body-shell for pouring oil and spice mixture therein.

i. tada f.s.: tension 1igature from cow hide.

j. tsarkiya f.s. = tsirkiya f.s.: membrane lacingthongs sewed at their lower end to kirinya, from cow hide.

3. Slightly divergent performance practices obtain in Katsina and Zaria, these being:

3.1. In Katsina, Gwabron Tambari is always beaten on its own with separate strokes from a single dorina, the drum being supported by two men, one on each side, each holding a handle attached to the body-shell. It is beaten only for the installation of the Emir and certain of his officials whose offices are of historical rather than current importance, the number of strokes for each such installation being traditionally prescribed, as is the identity of the official (not musician) performing the beating. 
Performances on the other tambura are of two kinds :

a. Stationary performances in which five tambura are beaten. Three fork-ended poles are driven into the ground in a line, two tambura being hung on each of the two outside poles and one tambari on the central pole. The central drum is beaten by Tambura, the official in charge of these drums, while two of his assistants beat the two outer pairs of drums, all of the performers using a dorina in either hand. The most common phrase beaten is:

Kuyangi ko fito da rabanmu ciki

"As for the female slaves -- come out, for our share is inside!", a phrase deriving from the tradition that any women found in a public place while tambura were being beaten immediately became state slaves.

b. Processional performances in which six tambura are beaten, mounted in pairs on three camels.

3.2. In Zaria, performances on the tambura are of two kinds :

a. Stationary performances in the 'dakin tambari, in which two large fork-ended poles are fixed in the floor, one supporting the 'yan 'dai-'dai and the other the salo-salo by means of two cowhide loops attached to each drum. The Sarkin Tambari, who beats the salo-salo pair, and his assistant, who beats the 'yan 'dai-'dai', sit on a special stair-step bench while beating them. The 'yan 'dai-'dai ("one by one") are struck alternately, maintaining a steady rhythm with either one or two dorina. The salo-salo ("of different kinds"), beaten with a dorina in each hand, are used to express the royal take, the most common phrase being:

Alhaji 'dan mutanen gabas "Alhaji, son of the people of Mecca."

One or two kuntukun tambari are placed upright on the floor and each is beaten by a seated drummer with a dorina in each hand.

b. For royal cavalcades (hawan salla and hawan daushe), a pair of tambura are mounted on one 
came1 and a pair of kuntukun tambura are mounted on another camel.

4. In Katsina used as a set without the addition of any other instruments; however, in Zaria, the royal kakaki is occasionally blown with the tambura.

5. Occasions for beating tambura are traditionally prescribed, and vary considerably between Emirates, as shown below:

5.1. Daura Emirate

a. When the crescent moon for the month of Rajab (the 7th Muslim month) is seen. This is the watan azumin tsoffi or "month of the fast for

b. At the end of the above month.

c. When the crescent moon for the month of Ramadan is seen. This is the watan azumin duk gari, or "month of the fast for al1 the town."

d. When the above month is over, tambura are beaten every evening for a week.

e. When the crescent moon for the month of Zul Haji (the 12th Muslim month) is seen. This is the month of the "Great Feast" or Babbar Sa1la.

f. On the ninth night of Zul Hajj, the eve of Babbar Sa11a.

g. On the morning of Babbar Salla.

h. When the crescent moon for the month of Rabi'i Lawwal (the 3rd Muslim month) is seen. This is the month of Maulud, the "Prophet's Birthday."

i. On the morning of Maulud.

j. On the eighteenth night of Rabi'i Lawwal, the eve of Sallar Takutufa, the Prophet's Naming Day.

$k$. On the morning of Sallar Takutufa.

1. When the crescent moon for the month of Muharram (the 1st Muslim month) is seen. This is the watan wowwo, or the "month of wowwo," the month 
in which gifts are exchanged between certain groups of people (e.g., hunters and scholars, barbers and blacksmiths, people of Gobir and Kano, people of Katsina and Zaria, or first cousins, grandchildren and their grandparents, etc.) or jokes played on one another by the same groups of people.

m. On the nineteenth day of Muharram, the day of wowwo on which the above exchanges take place.

$\mathrm{n}$. On the installation of a new Emir, on which occasion the latter beats the largest tambari himself twelve times.

o. On the installation of either a new Galadima, or a new K'aura, the two most senior district heads.

5.2. Katsina Emirate

a. On the eve of K'aramar Salla, the feast marking the end of the month of Ramadan.

b. On the day of K'aramar Salla and thereafter, morning and evening for a week.

c. On the eve of Babbar Salla, the ninth night of Zul Hajj.

d. On the day of Babbar Salla and thereafter, morning and evening for a week.

e. On the installation of a new Emir, on which occasion also the senior District Head, Galadima, beats Gwabron Tambari twelve times.

f. On the installation of a new K'aura, Galadima, Durbi, Sarkin Sullu'bawa or 'Yan 'Daka, a11 senior district heads, Gwabron Tambari alone is beaten six times in each case by Tambura.

g. On the installation of certain district and village heads, an ordinary tambari alone is beaten three or four times by Tambura, the number of strokes depending on the identity of the office.

$h$. On the conferment of any signal honour on the Emir a set of tambura are beaten by Tambura and his assistants. 


\subsection{Zaria Emirate}

a. On the day of K'aramar Salla for the hawan salla and thereafter for one month after each of the daily prayers and intermittently throughout the night, and whenever the Emir leaves the palace or returns. The Sarkin Tambari sleeps and eats in the 'dakin tambari throughout this month.

b. As above on the day of Babbar Salla and thereafter for one month.

c. For a second royal cavalcade, hawan daushe, held two days after each of the feasts of K'aramar Salla and Babbar Salla.

d. On the installation of a new Emir and thereafter for at least one month.

e. On the installation of a new Madaki, a senior official, and thereafter for seven days.

f. On the installation of a new Galadima, a senior official, and thereafter for 3 to 7 days.

6. Some idea of the enormous social and political significance of tambura may be obtained from the various traditional and other sayings connected with these drums.

a. kirarin tambari:

Tambari bugun mutun 'daya

"Tambari, beaten for one man (the Emir) alone."

Tambari a ji ka sama

"Tambari, you are heard (even) in the heavens."

Tambari wan ganga

"Tambari, the elder brother of ganga."

b. Poetry from Gangan Wa'azu:

Kun san dai matacce ba zai falka ba ko da ana ka' da masa gobron tambura

"You know surely that a dead person will not come back to life even if one beats a tambari for him." 
c. Kirari for victor in foot-boxing contest (a sha k'afa):

Ga mai tambari da sawu ga mai dukan a fa'di

"Here is the tambari drummer, who beats with his foot and knocks his opponent to the ground."

d. Traditional belief:

The tambari is said to beat once by itself when the Emir's successor walks by.

taushi m.s. (p1. tafashe, tausaye)

$=$ tabshi m.s. (p1. tafashe, tabsaye)

$211.11-852$

$=\underline{\text { zambuna }} \mathrm{f} . \mathrm{s}$.

1. Single-membrane snared bowl-shaped drum. Length of body-she11 - 11"; diameter of membrane - 9".

a. awara f.s.: iron lacing-ring around base of body.

b. danko m.s. = nake m.s.: wax layer on centre of membrane.

c. fata f.s.: membrane from goat or duiker skin.

d. ido m.s.: hole in side of body-shell for pouring oil and spice mixture therein.

e. kirinya f.s.: membrane lapping-ring from rope sewn in leather.

f. ma'dauki m.s.: carrying strap attached to bodyshell.

g. taushi m.s.: wooden body-shell carved from faru, kalgo, or k'irya trees.

h. tsarkiya f.s. = tsirkiya f.s.: 1eather lacingthongs attached at their lower ends to awara.

i. zaga f.s. = zaiga f.s.: snare on membrane.

3. Either placed in lap of the seated player so that the membrane may be beaten, on or off the wax layer, with the fingers of either hand, or carried suspended from the left shoulder so that the membrane may be similarly beaten. 
4. Used with one or more other tafashe in the accompaniment of song.

5. Used by the musicians of an Emir or senior official for the accompaniment of songs in honour of their patron or his associates. See masu taushi, marok'an sarakuna, marok'an Sarki.

turu m.s. (p1. turaye)

1. Small single- or double-membrane cylindrical drum with a body-shell made from a tin-can or other suitable container.

3. Beaten with the fingers of either hand.

4. Used on its own or in the accompaniment of informal song.

5. Used by children for self-amusement.

zambuna f.s. and $\mathrm{pl}$.

$211.261 \cdot 2-8$

$$
\circ \cdot \mathrm{p} \text {. }
$$

1. Pair of unique, single-membrane, goblet-shaped drums with closed ends.

3. Suspended from the left shoulder so that each lies in a near horizontal position at waist level with the membrane to the front. Beaten with a right-hand stick and the fingers of the left hand.

4. Used as a set for the performance of take and/or the accompaniment of song.

5. Ownership of zambuna is vested in the office of Mara'di, the Village Head of Kurfi in Katsina Emirate, for whom they are traditionally beaten.

6.a. kirarin zambuna:

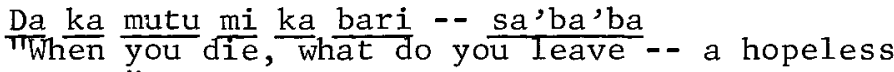
mess."

Mak'i maganar banza na Abu

"Hater of worthiess chatter, one of Abu." 
3) Chordophones

garaya f.s. (p1. garayu)

1. Generic term for a two-stringed plucked lute occurring in two main sizes, as below:

1.1. garaya f.s.: the smallest member of this family, with a carved ovoid wooden body-resonator. Overal1 length, including neck - 22"; length of exposed neck - 12"; length of vibrating strings $16^{\prime \prime}$.

1.2. babbar garaya f.s. (the "big garaya") = komo m.s.: the largest member of this family, with an ovoid gourd body-resonator. Overall length, including neck and iron jingle at the end thereof - 70"; length of jingle - 30"; length of exposed neck $22 "$; length of vibrating strings - 32".

2.a. amale m.s. ("huge camel") = giwa f.s. ("elephant") t tambari m.s.: the lowest pitched of the two strings, each with the same vibrating 1 ength but tuned at an interval of approximately 500 cents.

b. ceba f.s.: long, rectangular iron jingle with smaIl wire rings set into holes around its edge; attached to the end of the neck of babbar garaya.

c. farke m.s. = farko m.s.: small leather plectrum from cow's hide.

d. fata f.s.: membrane covering body-resonator from goat or duiker skin.

e. kallabi m.s.: leather thongs binding strings to neck.

f. k'ok'on garaya m.s.: body-resonator of the small garaya.

g. komo m.s.: body-resonator of babbar garaya or komo.

h. kurman 1aya m.s.: talisman attached to neck of garaya, usually a written passage from the Koran sewn in a leather pouch. 
i. magu'diya f.s. (the "ululator"): the highestpitched of the two vibrating strings.

j. sandar gamu m.s.: the neck.

k. tsarkiya f.s. = tsirkiya f.s.: generic for both vibrating strings on either instrument.

3. The instrument is held at the neck-end by the left hand with the fingers in position to stop either string; the body-resonator rests against the player's waist, or in his lap if seated, and the strings are plucked with the right-hand plectrum.

4. Used solo with caki, or kasam'bara, or with caki or kasam'bara in the joint accompaniment of song and/or dancing; solo with one or more other garayu and caki or kasam'bara, or as a group in the accompaniment of song and/or dancing.

5. Used by men for the performance of music of various types. Originally garaya was used for music in honour of hunters, and in particular for praising hunters in their traditional rivalry with malamai; it is today less restricted in use and is employed for such different types of music as songs of entertainment (wak'ar nasha'di), praise songs (wak'ar yabo) and songs of possession (wak'ar bori). In Zaria the garaya is used mainly for bori ceremonies, and the komo or babbar garaya is played for hunters (maharba). See masu garaya and masu komo.

6.a. kirarin garaya:

Gangar maharba

"Drum of the hunters"

Garaya kim fi mugunyar mata

"Garaya, you are better than a bad woman."

goge m.s. (p1. goguna)

$321.311-71$

no.p.

1. Single-stringed bowed 1ute. Overal1 length - 26"; length of exposed neck - 15"; length of vibrating string - $15 "$ ".

2.a. fata f.s.: membrane covering body-resonator from the skin of the Nile monitor. 
b. izga f.s. = yazga f.s. = tambara f.s.: iron- or bronze-backed bow with hairs from a horse's tail.

c. jaki m.s.: bridge between string and body-resonator from a three-pronged twig of the urkure tree.

d. k'ahon butsiya m.s.: small horn-like wedge inserted between lower end of string and body-resonator to increase tension of former.

e. kallabi m.s.: leather binding thongs securing strings at upper end to neck.

f. k'ank'ara f.s.: smooth egg-shaped stone inserted under membrane-covering of body-resonator to increase tension of the former.

g. kanwa f.s.: potash used to remove the natural oils from the body and bow-strings.

h. k'aro m.s.: resin for body and bow strings from Copaiba balsam tree.

i. kumbo m.s.: hemispherical body-resonator from a latitudinally cut half-gourd.

j. tsagiya f.s.: string on body-resonator from hairs from a horse's tail.

k. wuri m.s.: a cowrie-she11 used 1ike k'ank'ara, above.

3. Held at the neck-end by the left hand with the fingers in position to stop the string; the body-resonator rests against the player's waist, or in his lap if seated, and the string is bowed with a nearly vertical up and down action by the right hand bow.

4. Used solo, solo with one or more $k$ 'warya, solo with one or more kalangu and 'dan kar'bi, or with combinations of the above in the joint accompaniment of songs and/or dancing.

5. Used by men for the performance of music of various types, e.g., songs of entertainment (wak'ar nasha'di), songs of praise (wak'ar yabo), political songs (wak'ar siyasa), possession songs (wak'ar bori). Made immensely popular by the artistry of such performers as Audu Yaron Goge and Garba Liyo. See masu goge, bori, rawan kashewa, Sarkin Goge. 
6.a. kirarin goge:

Yazgar marigyayi ko malan ba ya cewa ba da'di sai dai ya ce babu kyau

"Hairs of the dead horse, not even a religious teacher can say you are not sweet to the ear, he can only say you are not edifying."

Goge mai kashe wa molo kaifi

"Goge who silences the mob" (i.e., it is louder).

Goge ki'dan 'yan duniya ne

"Goge is the music of worldly people."

Goge kan bidi'a ke nan

"Goge is the source of heresy."

gurmi m.s. = kumbo m.s.

$321.311-5$

no.p.

1. Two-stringed plucked lute with hemispherical bodyresonator. Overall length, including neck - 24"; length of exposed neck - 18"; diameter of body-resonator - 6"; length of vibrating strings - 18".

2.a. amale m.s. (the "huge came1") = giwa f.s. (the "elephant") = tambari m.s.: the lowest pitched of the two strings, each made from twisted hairs from a horse's tail and tuned at an interval approaching 700 cents.

b. fata f.s.: membrane covering body-resonator, from skin of land monitor.

c. kallabi m.s.: leather binding-thongs securing strings at their upper end to the neck.

d. kara f.s.: bridge between vibrating strings and membrane-covering of body-resonator, from a short length of guinea corn stalk with 'ya'yan baba inserted in ends.

e. kumbo m.s. = kurtu m.s.: hemispherical body-resonator from a latitudinally cut half-gourd.

f. magu'diya f.s. (the "ululator"): highest pitched of the two vibrating strings.

g. tsarkiya f.s. = tsirkiya f.s.: generic for both vibrating strings. 
h. 'ya'yan baba pl.: seeds of the indigo plant inserted in either end of the bridge to give a characteristic "buzzing" sound to the instrument.

3. Held as for garaya, with the lowest-pitched string uppermost; the lowest-pitched string is plucked with the right-hand thumb, and the highest-pitched string with the right-hand index finger.

4. Used solo or in the accompaniment of song.

5 . Used by men for various types of music, but especially sung in praise of 'yan kokuwa. See masu gurmi.

jita m.s. (d.f. English, guitar)

$321.322-6$ no.p.

1. Imported western guitar.

3. Normal technique.

4. Used as an accompaniment instrument in solo singing.

kukuma f.s. (pl. kukumai)

$321.311-71$ no.p.

1. Single-stringed bowed lute similar to, but smaller than goge. Overall length including neck - 20"; length of exposed neck - 12"; 1ength of vibrating string $-9.5^{\prime \prime}$.

2. As for goge, with the exception of:

a. jaki m.s.: bridge inserted between string and membrane covering body-resonator, from a "u" shaped section of guinea corn stalk cut from the top of the plant as it bends over before harvesting.

b. k'ahon mariri m.s.: small oryx horn used as a wedge between the string at its lower end and the body-resonator in order to increase the tension of the former.

3. As for goge, except that the body-resonator rests closer to the chest than the waist. 


\section{As for goge.}

5. Made popular by the artistry of such performers as Ibrahim $\mathrm{Na}$ Habu and Ali 'Dan Saraki. Used as is goge but by men and women and professionals and nonprofessionals. See masu kukuma, masu wak'ar kukuma.

6.a. karin magana:

Abin da ya kai tsafuwa rawar kukuma -- tare ielanta

"What made the old woman dance to kukuma was that she was collecting her tail feathers," i.e., "No one acts without a motive, however ridiculous."

kuntigi m.s. (p1. kuntuga)

$321.311-6$

$=$ kuntugi $\mathrm{m} . \mathrm{s}$. no.p./np.

1. Single-stringed plucked 1ute. Overall length, including neck - 12.5"; length of exposed neck - 6.5"; length of vibrating string - 11".

2.a. ceba f.s.: metal jingle attached to end of neck on some instruments but not used by such wellknown performers as 'Dan Maraya and Mai Kur'di 'Dan Duna.

b. gora f.s.: neck from a length of thin bamboo.

c. gwangwanin kifi m.s.: body-resonator from an ovoid herring tin with the top removed, or from a sardine tin.

d. tantanin dalo m.s.: membrane covering body-resonator from calf's skin.

e. tsagiya f.s.: string from twisted camel hairs.

3. Held as for garaya, but with the body-resonator closer to the chest than to the waist; plucked with a right-hand plectrum from the quill of a vulture's feather.

4. Solo in the accompaniment of song, or with one or more other kuntuga in the accompaniment of song. 
5. Used by men and, less often, by women for the accompaniment of various types of song, e.g., songs of entertainment (wak'ar nasha'di), political songs (wak'ar siyasa) and praise songs (wak'ar yabo). See masu kuntigi.

molo m.s. ( $\mathrm{pl} \cdot \underline{\text { molaye })}$

tafashe m.s.

1. Three-stringed plucked lute. Overall length, including neck - 27"; length of exposed neck - 10"; lengths of vibrating strings - 14", $22^{\prime \prime}, 22^{\prime \prime}$.

2.a. amale m.s. (the "huge camel") = giwa f.s. (the "elephant") = tambari m.s.: the lowest pitched of the three strings tuned at intervals approaching 500 and 700 cents upwards (i.e., so that the highest string is approximately an octave above the lowest), and each made from hairs from a horse's tail twisted together.

b. fata f.s.: membrane covering body-resonator from goat's or duiker skin.

c. gora f.s.: neck from a length of thin bamboo.

d. ice m.s.: wooden body-resonator carved to a trough-iike shape from the tumfafiya tree.

e. kallabi m.s.: leather thongs securing the strings

f. magu'diya f.s. (the "ululator"): shortest and highest pitched of the three strings.

g. sha ki'di m.s. ("undergo the beating"): the middle-pitched of the three strings.

h. tsarkiya f.s. = tsirkiya f.s.: generic for any of the three strings.

3. Held as for garaya, except that the shortest string is not stopped but supplies a drone; the lowest pitched string is plucked with the thumb of the right hand, and sha ki'di with the index finger, a11 fingers of the right hand being used to tap the membrane covering the resonator periodically. 
4. Used solo, solo with caki or kasam'bara, or in combinations of the above in the joint accompaniment of song.

5. Used by men, both amateurs and professionals, for the accompaniment of various kinds of song, but traditionally for the accompaniment of songs in praise of famous warriors. See masu molo.

\section{4) Aerophones}

algaita f.s. (d.f. Arabic al raita);

422.112-7

(pl. algaitai) $=$ raha $\mathrm{f} . \mathrm{s}$.

1. Double-reed vibrated pipe of conical bore. Length, including mouthpiece and reeds - 21"; diameter of mouthpiece bore - .5"; diameter of lower end of pipe - 2.5".

2.a. algaita f.s.: wooden be11-ended pipe carved from daniya tree.

b. garkuwa f.s.: round brass disc forming end of reed-holder.

c. haki m.s. = macara f.s. = sheme m.s.: double-reed cut from suitable grass stalk and prepared by boiling with meat fat, onions and spices.

d. jakar algaita f.s.: 1eather carrying-bag.

e. kwarkwaro m.s.: complete brass reed-holder including garkuwa, above.

f. tsahi m.s.: narrow-bore of neck of pipe.

g. wutaci m.s.: each of the four fingerholes bored in the wooden pipe.

3. Held by both hands in a near-horizontal position, with the left hand positioned towards the bell end. The fingerholes are stopped by the index finger of the right hand and the index, second and third fingers of the left hand, and the instrument is blown with the cheeks acting as an air reservoir. 
4. Used solo with gangar algaita or with one or more other algaitai and gangunan algaita or with kakakai (kakaki), farai and gangar fada.

5. Used by musicians of senior officials, not of the Emir in Katsina and Zaria, for the performance of take and in the accompaniment of songs of praise in honour of their patron or their associates. See masu algaita, marok'an sarakuna, Magajin Busa and Sarkin Maka'da.

begila f.s. (d.f. English, bugle) no.np.

1. Imported Western military bugle.

3. Normal technique.

4. Normal band combinations.

5. Normal band usage.

bututu m.s.

423.121 .11

1. Lip-vibrated end-blown pipe formed from a length of a hollow stem of a pawpaw leaf.

5. Used by children for self-amusement.

dama1go m.s.

422.31

no.np.

1. A transversely blown, single beating-reed, idioglot pipe which is similar to til'boro but larger, with a finger hole and a gourd resonance chamber on the distal end of the tube.

2. As for the til'boro, except for the following:

a. damalgo: two sections of guinea corn stalk cut to Form a pipe open at both ends, 21 " in length.

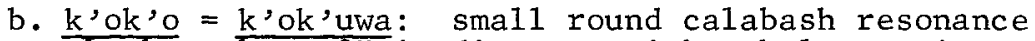
chamber about $3^{\prime \prime}$ in diameter with a hole cut in its side to attach it to the distal end of the 
pipe. There are four other holes cut into its surface, each about $1 / 2^{\prime \prime}$ in diameter, permitting the escape of sound.

3. As with til'boro, except the finger hole at the distal end of the pipe is stopped with the left thumb.

4. Solo or in the accompaniment of song and dance.

5. Used by young men for their own pleasure or to earn small change, especially during the month of Ramadan. See 'yan dama1go.

farai m.s. = famfami m.s.

(pl. famfamai)

$0 \cdot \mathrm{p}$.

1. Wooden, lip-vibrated, end-blown pipe. Length - 32"; bore at mouthpiece - .5"; bore at bel1 end - 2.5 ".

2.a. falami m.s. = fallami m.s.: wooden mouthpiece section carved from alilliba or gwandar jeji trees.

b. gora f.s.: middle section from a length of bam-

c. k'ofa f.s.: bore of mouthpiece.

d. maratayi m.s.: cloth carrying-strap.

e. rami m.s.: bore of middle and end-sections.

f. turmi m.s.: bell-end section, carved from wood of alilliba tree or formed from metal from a kerosine tin.

3. Held to the mouth in a near-horizontal position by the player's right hand at the mouthpiece end and left hand near the bell end.

4. In combination with kakakai (kakaki), gangar fada, and, in Zaria, k'aho.

5. Used by the musicians of an Emir for the performance of praises in honour of their patron, though musicians of other senior officials in Zaria formerly used them. See masu farai and Magajin Busa. 
6.a. kirarin farai:

Farai busan mutun 'daya

"Farai, blown for one man alone (the Emir)."

k'aho m.s. (p1. k'ahoni)

423.122 .2

$0 . \mathrm{p}$.

1. Side-blown 1ip-vibrated animal horn.

2.a. k'ofa f.s.: embouchure, cut into side of horn

b. maratayi m.s.: cord carrying-strap.

c. Shata f.s.: horn of the female roan antelope used to construct the instrument body.

d. turmi m.s.: bell-end from oxhorn attached to shata with beeswax.

3. Held to the mouth in a near-horizontal position with the right hand near the tip and the left hand towards the bell end. The forefinger stops the open tip end and the fingers of the left hand are placed over the be11 end.

4. Solo or in combination with kakaki, farai and gangar fada.

5. Used by the musicians of an Emir for the performance of praises in honour of their patron. In Zaria it was also formerly used by other senior officials. See masu k'aho, Sarkin Busa, marok'an sarakuna, marok'an Sarki.

kakaki m.s. (d.f. Songhay ?)

(p1. kakakai)

423.121 .12

$0 . \mathrm{p}$.

1. Long, metal, 1ip-vibrated, end-blown pipe in two detachable sections. Overall length between 8 feet and 14 feet, depending on the area, the following measurements applying to an average instrument in Katsina: overal1 length - 97"; length of mouthpiece section - 48"; 1 length of bell-end section - 49"; bore at mouthpiece - 1"; bore immediately before ac- 
tual bel1 end - 2.75"; maximum diameter of bell end - 4".

2.a. home m.s.: actual bell end from metal of kerosine tin or thin brass.

b. jakar kakaki f.s.: leather or cloth carrying-bag.

c. karan kakaki m.s.: the long thin part of the mouthpiece section from metal of kerosine tin or thin brass.

d. magu'diya f.s. (the "ululator"): actual mouthpiece from metal of kerosine tin or thin brass.

e. uwa f.s. (the "mother"): complete bel1-end section from metal of kerosine tin or thin brass.

f. 'ya f.s. (the "daughter"): complete mouthpiece section.

3. Held to the mouth in a near-horizontal position with the right hand near the mouthpiece and the extended left arm towards the bell end. Blown to produce two notes approximately 750 cents apart; a third note at an interval of approximately 100 cents below the lowest of the two previous notes, is less commonly used. When a group of kakakai are used for "solo and chorus" type performance, the "chorus" instruments are approximately 100 cents higher in pitch than the "solo" instrument throughout their range.

4. Used solo, solo with one or more other kakakai, as a group with gangar fada, as a group with gangar fada and farai, and as a group with gangar fada, farai and k'aho. Occasionally the Sarkin Kakaki of the Emir of Zaria plays with tambura. All the above performances being based on the instrumental realization of one or more take and the vocal realization of a kirari.

5. Used by the musicians of an Emir for performances in honour of their patron or his associates. More rarely, as in Zaria, kakaki may be owned by a lesser official but, if so, only with the approval of the Emir. See masu kakaki, Sarkin Busa, marok'an sarakuna.

6.a. kirarin kakaki:

Kakaki busan mutun 'daya

"Rakaki, blown for one man alone (the Emir)." 
Barawon kakaki ba shi da iko ya busa shi

"The man who steals kakaki still does not have the authority to blow it."

sarewa f.s. = mabusa f.s.

421.111 .12

=sheshe m.s. no.p./np.

1. End-blown flute with four finger-holes. Overall length - 22"; bore - 1". Cut from length of guinea corn stalk and bound with the bark of the kalgo tree.

3. Held in a near-vertical position with the left hand above the right hand, the index and third fingers of both hands being used for stopping, the instrument is blown out of the side of the mouth.

4. Used solo, solo with kasam'bara, or with kasam'bara in the joint accompaniment of song.

5. Used by men for cattle herding or, less commonly, for music for entertainment (wak'ar nasha'di) or possession (wak'ar bori). See masu sarewa.

til'boro m.s. = tillik'o m.s.

1. A transversely blown, single beating-reed, idioglot pipe.

2.a. belu m.s. = beli m.s.: reed cut from section of actual pipe $\overline{\text { near }}$ closed end of latter.

b. til'boro m.s.: section of guinea-corn stalk cut to form a pipe open at both ends, about 1 foot in length and $1 / 2 "$ in diameter.

c. zare m.s.: a piece of thread tied loosely around the vibrating reed to control the movement of the latter.

3. Held to the mouth so that it covers the reed, the pipe being in a near-horizontal position with the right hand at the reed end and the left hand at the open end. The reed is vibrated by either blowing or sucking, the index finger of the 
left hand being used to stop the open end of the pipe.

4. Used solo or with other til'boro.

5. Used by children and young men for amusement.

\section{B. TERMS FOR PARTS OF INSTRUMENTS}

While terms referring to parts of instruments are listed under the instruments to which they belong, they do as a body demonstrate a certain standardization of terminology not only among instruments of the same genre, but also among those from completely different families. For this reason all such terms, whether standardized or not, have been extracted and are presented in a list immediate1y hereunder, together with a brief description of their general provenance:

akushi m.s. ("a large wooden bowl") = akwashi m.s.: wooden body-shel1 of tambari carved from ka'danya or maje trees.

algaita f.s.: wooden body of the aerophone of that name carved from daniya tree.

amale m.s. ("a large came1"): lowest pitched of the strings on garaya, gurmi, and molo and also termed giwa and tambari.

awara f.s.: iron lacing-ring around the base of banga and taushi.

banga f.s.: wooden body-shell of the drum of that name, carved from alilliba (= aluluba), katsari or k'irya trees.

belu m.s. = beli m.s.: beating reed cut from section of guinea corn stalk or til'boro.

bulala f.s.: hippopotamus-hide beating thongs used on tambari and more specifically termed dorina. 
buta f.s.: bottle-shaped gourd used for body of the rattle known as caki.

ceba f.s.: jingle from a length of thin metal pierced around its edges with wire rings, attached to kwairama, gangar noma, garaya, and some examples of kuntigi.

cinki m.s. = tsinke m.s.: large iron needle for replacing membranes, and attached to the side of that member of the dundufa drum set known as magu'diya.

dagarya f.s.: hide-lapping ring around membrane on jauje.

'dan kawo m.s.: seeds of the kawo tree placed inside the body-shell of jauje.

danko m.s.: wax layer on centre of membrane of taushi; also termed nake.

daro m.s. ("a metal basin") = bronze-cased wooden bodyshell of certain examples of tambari.

dauri m.s.: leather strap attached at one end to the constricted waist of kalangu and 'dan kar'bi drums and used for tying in the tensioning thongs when the drums are not in use or when a fixed pitch is required; also termed $\mathrm{k}$ 'angu.

dorina f.s.: specific term for hippopotamus-hide beating thongs used on tambari and also known as bulala.

duma m.s.: generic for a number of kinds of gourd among which are the bottle-shaped gourd used as a body for the rattle caki, and the large barrel-shaped gourds used for the body-shells of the drums forming the duma and duman girke sets.

falami m.s. = fallami m.s.: wooden mouthpiece section of farai carved from alliliba (= aluluba) or gwandar jeji trees.

farke m.s. = farko m.s.: small leather plectrum from cow's hide used with garaya.

fata f.s.: generic term for the membrane on such drums as banga, duma, duman girke, dundufa, ganga, gangar 'yan kama, kotso, and taushi; also generic for the membrane covering on the body-resonators of such stringed instruments as garaya, goge, gurmi, and molo. 
furya f.s.: wooden body-shells of the drums belonging to the set known as dundufa carved from alliliba $(=$ aluluba $)$, kawo or k'irya trees.

galura f.s. = garura f.s.: bottle-shaped gourd used for the body of the rattle known as caki.

garkuwa f.s.: round brass disc forming end of reed-holder on algaita.

giwa f.s.: lowest-pitched of the strings on garaya, gurmi and molo; also termed amale and tambari.

gora f.s.: length of bamboo used as a neck for kuntigi and molo and for the middle section of farai.

gwangwanin kifi m.s.: ovoid herring or sardine tin used as a body-resonator for kuntigi.

gyan'dama f.s.: bottle-shaped gourd used as a body for the rattle known as caki.

haki m.s.: double-reed cut from a length of grass stalk, boiled with meat fat, onions and spices, and used for algaita; also termed macara and sheme.

home m.s.: bell-end of kakaki made from kerosine tin or thin brass pan.

hurya f.s.: beating-stick for such drums as dundufa, ganga, and jauje, from aduwa, geza or sabara trees or if hook-ended from root of gabaruwa tree; also termed maka'di.

ice m.s.: wooden body-shell of such drums as ganga, kalangu, kotso and kuntuku and wooden body-resonator of molo; carved from such trees as alliliba (= aluluba), kawo, kimba, k'irya, maje, marke, and in the case of molo, tumfafiya tree; in the case of drums also termed kango (= kwango).

idon zakara m.s.: small seeds placed inside body-shell of ganga.

ido m.s.: hole in the side of the body-shell of such drums as dundufa, kuntuku, and taushi; also termed k'ofa.

izga f.s. = yazga f.s.: iron- or bronze-backed bow with string from the hairs of a horse's tail, used on goge and kukuma; also termed tambara. 
jaka f.s.: leather carrying-bag for algaita and kakaki.

jaki m.s.: bridge between membrane on body-resonator and string on goge and kukuma, in the former case from a three-pronged twig of the urkuru tree, in the latter case from the " $u$ " shaped stalk cut from the top of a guinea-corn plant as it bends before harvesting.

kafar zuba mai f.s.: hole in the side of the body-shell of banga; also termed $k$ 'ofar zuba mai.

k'aho m.s.: small horn used as a wedge for increasing the tension of the string on goge and kukuma.

kallabi m.s.: leather thong binding the string or strings to the neck on such instruments as garaya, goge, gurmi, and molo.

kambu m.s.: leather lapping-ring around the membrane of kalangu; also termed kirinya.

kango m.s. = kwango m.s.: wooden body-shell of such drums as dundufa, ganga, gangar 'yan kama, kalangu, kazagi, kotso, and kuntuku; carved from alliliba, kawo, $k$,irya, kimba, marke, and maje trees; also termed ice.

k'angu m.s.: leather-strap attached to the constricted waist of such drums as kalangu, 'dan kar'bi and kazagi, and used to tie the tensioning cords in when not in use, or when a constant pitch is required; also termed 'dauri.

k'ank'ara f.s.: smooth egg-shaped stone inverted under membrane covering of body-resonator to increase the tension of the former, on such instruments as goge and kukuma.

kan tandu m.s.: base of the instrument known as tandu.

kanwa f.s.: potash used to remove the natural oils from the body and bow-strings of goge and kukuma.

kara f.s.: bridge from a short length of guinea-corn staik with seeds of the indigo plant inserted in the ends, used on gurmi; the long thin tube of the mouthpiece section of kakaki, made from kerosine tins or thin brass pans.

k'aro m.s.: resin for body and bow-strings of goge and kukuma, from the Copaiba balsam tree. 
kayan yaji m.s.: oil and spice mixture poured through a hole in the side of tambari; made from man shanu ("butter"), zuma ("honey") and barkono ("red pepper"), citta mai kwaya, fasakwari, citta kulla, karamfani, citta mai yatsu, kimba, masoro, as we11 as albasa ("onions").

kirgi m.s.: membrane from bul1- or cow-hide on tambari.

kirinya f.s.: hide-ring lapping the membrane on such drums as banga, dundufa, ganga, kalangu, kazagi, kotso, and taushi; also iron lacing-ring around base of tambari, also termed zobe.

k'ofa f.s.: bore of embouchure of such instruments as farai and $\mathrm{k}$ 'aho.

k'ofar tsarkiya f.s.: holes drilled around edge of open end of body-shell of kotso for securing lacingthongs.

k'ofar zuba mai f.s.: hole drilled in side of body-she11 of such drums as banga and dundufa.

k'ok'o m.s.: cut gourd used as body-resonator of the sma11 garaya.

komo m.s.: cut gourd used as body-resonator of the large garaya or komo.

kumbo m.s.: cut gourd used as body-resonator of goge and and gurmi; also termed kurtu.

k'ungu m.s.: leather lapping-ring around membrane of such drums as gangar 'yan kama and kuntuku.

kurman laya m.s.: talisman attached to the neck of garaya and made from a written passage from the Koran sewn up in a leather pouch.

kurtu m.s.: cut gourd used as body-resonator of gurmi; also termed kumbo.

kwarkwaro m.s.: complete brass reed-holder of algaita.

liko m.s.: plug for the hole in the side of the bodyshell of banga.

ma'dauki m.s.: carrying-strap on such drums as banga, ganga, kotso and taushi; also termed maratayi. 
magu'diya f.s.: highest pitched of the strings on garaya, gurmi, and molo, and the mouthpiece of kakaki.

maka'di m.s.: beating stick for such drums as dundufa, ganga, kalangu, and kazagi; if straight, from aduwa, geza or sabara trees; if hook-ended, from root of gabaruwa or sanya trees; also termed hurya or gula.

mak'ogaro m.s.: open end of body-shell of kotso.

man gya'da m.s.: ground-nut oil poured through hole in side of body-shell of dundufa.

maratayi m.s.: carrying-strap on such drums as banga, ganga, kotso, and on such aerophones as farai and k'aho.

marfi m.s.: plug for the hole in the side of tambari. murfi m.s. = mulhi m.s.: cloth covering body-shell of ganga.

nake m.s. = nike m.s.: wax layer on centre of membrane of such drums as banga, kotso and taushi; made from finely sifted laterite subsoil and pounded fruit of the aduwa (date palm) tree; also termed dank'o.

rami m.s.: hole in side of body-shell of tambari and bore of middle and end sections of farai.

rici m.s.: membrane lacing-thongs on banga.

riga f.s.: cloth covering body-shell of such drums as banga and gangar fada; also termed murfi.

rik'i m.s.: leather or iron lacing-ring around the base of such drums as dundufa.

saisaya f.s.: hide lapping-ring sewn to membrane of kalargu and 'dan kar'bi.

samfara f.s.: thin membrane on such drums as ganga, kalangu and kotso; from the skin of a young goat; also termed fata.

sandar gamu m.s.: the neck of garaya.

sha ki'di m.s.: the middle-pitched of the three strings on molo.

shata f.s.: horn of the female roan antelope, used for the body of $\underline{k}$ 'aho. 
ta'barya f.s.: pestle used with turmi

ta'da f.s.: tension ligature on tambari.

tambara f.s.: iron- or bronze-backed bow with string from hairs from a horse's tail, used on goge and kukuma.

tantanin dalo m.s.: membrane covering body-resonator of kuntigi, from calf-skin.

taushi m.s.: wooden body-shell of the drum of that name, carved from faru, kalgo, or k'irya trees.

til'boro m.s.: body of the pipe known by that name.

toto m.s.: plug for the hole in the side of the bodyshell of dundufa.

tsagiya f.s.: string of goge, kukuma and kuntigi, in the two former cases from the hairs from a horse's tail, in the last from camel hairs.

tsahi f.s.: narrow bore of the neck of the pipe known as algaita.

tsarkiya f.s.: membrane lacing-thongs on such drums as dundufa, ganga, gangar 'yan kama, kalangu, kazagi, kotso, kuntuku, tambari, taushi and generic for the strings on such instruments as garaya and molo.

tuke m.s.: fine thread of goat's skin used to sew saisaya to samfara on kalangu.

turmi m.s.: bell-end section of farai and $\mathrm{k}^{\prime}$ aho.

turu m.s.: leather thong strung through the holes around the open end of kazagi and used for securing lacingthongs.

uwa f.s.: complete bell-end section of kakaki, from kerosine tin or thin brass pan.

wuri m.s.: a cowrie shell inserted under membrane covering on goge and kukuma to increase the tension of the covering.

'yan sanduna p1.: pair of beating-sticks used on kuntuku.

'ya'yan baba p1.: seeds of indigo plant placed inside body-shell of kalangu and in ends of bridge on gurmi. 
$60 /$ GLOSSARY OF HAUSA MUSIC

zaga f.s. = zaiga f.s.: snare on membrane of such drums as ganga, gangar 'yan kama, kazagi, kotso and taushi.

zare m.s.: piece of thread tied loosely around the vibrating reed of til'boro.

zobe m.s.: iron lacing-ring around base of body-shell of tambari, also termed kirinya. 


\section{Professional \\ Performers}

\section{Outline}

\section{A. COLLECTIVE TERMS}

\section{B. CLASSES OF PERFORMERS}

1) Masu ki'da ("drummers")

a. Idiophonists ("Drummers on idiophones")

b. Drummers

c. Lutenists ("Drummers on chordophones")

2) Masu busa ("blowers")

3) Mawak'a ("singers")

4) Marok'an baki ("acclamators")

5) 'Yan magana ("talkers")

C. OFFICES AND TITLES OF PERFORMERS 


\section{A. COLLECTIVE TERMS}

mabusa, masu busa p1. (mai busa m.s.)

$=$ mabusa p1. (mabushi m.s.)

Performers on aerophones.

magu'da pl. (magu'diya f.s.)

Women specializing in celebratory ululating.

See gu'da.

maka'da pl. (maka'di m.s.)

$=\underline{m a s u} \mathrm{ki}$ 'da $\mathrm{pl}^{\prime}$ (mai $\mathrm{ki}$ 'da m.s.)

A generic term which embraces all sorts of "drummers." Players of membranophones, chordophones, and idiophones are all conceived of as "drummers."

See ki'da.

maka'dan hakimai p1. (maka'din hakimai m.s.)

Equivalent of marok'an hakimai.

maka'dan sarakuna

Equivalent of marok'an sarakuna.

maka'dan Sarki

Lit. "drummers of the Emir" but used generically for al1 his hornblowers, acclamators, and drummers.

Equivalent of marok'an Sarki.

marok'a p1. (marok'i m.s., marok'iya f.s.)

In general, any person who acclaims another, whether solicited or not, in the hope of obtaining reward as a means of livelihood. The acclamation may be expressed in song (wak'a) or speech (kirari), with or 
without instrumental accompaniment, or solely on musical instruments (take).

Act of acclamation = rok'o.

karin magana:

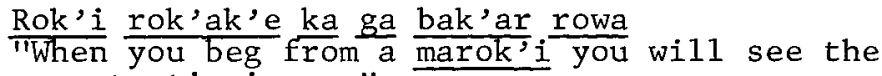
worst stinginess."

marok'an baki pl.

A collective term which embraces all sorts of professional acclamators who call kirari for their patrons: e.g., San K'ira, masu kirarí, 'yan ma'abba, bamba'dawa, kasken karen marok'a, and 'yan agalanda.

See marok'an baki in Part B, below, and rok'o and kirari in section $\mathrm{V}$.

marok'an hakimai or marok'an hakimi pl. (marok'in hakimi m.s.)

= masartan hakimi pl. (masarcin hakimi m.s.)

$=$ maka'dan hakimi pl. (maka'din hakimi m.s.)

Any marok'i in the regular service of a hakimi (district head or other high official, excepting the Emir).

Instruments played by the marok'a of various hakimai of Zaria (1963-64): kakakij; algaita; gangar fada; banga; jauje; taushi; kalangun Caji; kotso; gangar algaita; kazagi; and buta.

Instruments played by the marok'a of various hakimai of Katsina (1963-65): algaita; gangar fada; gangar algaita; banga; jauje; kotso; zambuna.

See marok'an sarakuna.

marok'an sarakuna p1. (marok'in sarakuna m.s.)

= masartan sarakuna pl. (masarcin sarakuna m.s.)

$=$ maka'dan sarakuna $\mathrm{p} 1$. (maka'din sarakuna m.s.)

A collective term for marok'a in the service of any high office-holder, including the Emir (the marok'an Sarki or masartan Sarki), high officials resident in 
the capital of the emirate and district heads (marok'an hakimai or masartan hakimai).

Some occasions of performance for sarakuna:

Daily -- some do rok'o in front of the patron's residence, and in Zaria City the Sarkin Busa, Sarkin Kakaki and Magajin Busa blow take for the Emir and high officials in attendance. But in Katsina the traditional unsolicited acclamation of officials, which was of daily occurrence, is now officially forbidden.

Weekly -- sara (= waza) usually on Thursday night in front of patron's residence; escorting him to and from the mosque on Friday; and greeting him afterwards, called gaisuwar juma'a.

Annually -- performances during K'aramar Salla and Babbar Sa11a for wazan sa11a, yawon salla, hawan salla, hawan daushe and hawan kilisa. Many accompany their patrons on his annual inspection tour.

Irregularly -- marok'an sarakuna derive considerable additional income from attendance during the morning of naming (suna) and marriage (aure) ceremonies, where they make announcements and, if permitted, sing, drum, blow and shout kirari. If it is their patron's ceremony, they also perform in the evening when the feast (buki) is held. They also perform at turbanings (na'din sarauta) of important and affluent persons upon their investiture in office. A visit of a "V.I.P." or the return of their patron from a long trip also require a performance. In Zaria, the Sarkin Busa and the Magajin Busa accompany the Emir on official business trips with the latter blowing his trumpet from a lead automobile to herald the Emir's coming. In Katsina, the main occasions are as above, but in addition the royal musicians are frequently invited to perform by various officials, within their households, on Thursday evenings immediately after the de rigeur sara in front of the Emir's palace. Once a year the masu ganga, masu kotso and masu kakaki make extended tours of the Emirate, visiting all district heads and important village heads in the process. 
marok'an Sarki p1. (marok'in Sarki m.s.)

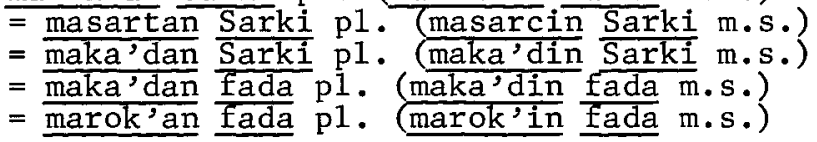

Any marok'i of an Emir including:

heads who are given a title in recognition of their position and turbanned as such by an Emir; assistants of the heads, some of whom have lesser titles given them by the heads and are turbanned by the head. (Note: a similar pattern is encountered among the marok'an hakimi.)

Titles of heads among the marok'a of the Emir of Zaria in 1964 in hierarchical order:

(i) Sarkin Busa; (ii) Magajin Busa; (iii) Sarkin Kakaki; (iv) Sarkin Maka'da; (v) Magajin Banga; (vi) Sarkin Jauje; (vii) Sarkin Taushi; (viii) Sarkin Kalangu ("acting"); (ix) Sarkin Bamba'dawa; (x) San K'ira. The head of the drummers of the tambura, the Sarkin Tambari, is a non-professional.

Titles of the heads of the various groups of royal musicians at the court of the Emir of Katsina in 1965, in hierarchical order, are:

(i) Sarkin Maka'da; (ii) Sarkin Busa; (iii) Sarkin Maka dan Kotso; (iv) Sarkin Bamba'dawa; (v) Magajin Banga; (vi) Sarkin Tabshi; (vii) Sarkin Farai; (viii) Zabaya, with Tambura, who is outside the hierarchical framework.

Instruments played for the Emir of Zaria by his marok'a:

k'aho; kakaki; farai; gangar fada; banga; jauje and kolo; taushi; kalangun Sarki; and kuge.

Instruments used by the musicians of the Emir of Katsina are:

tambari, gangar fada, kakaki, farai, kotso, taushi, banga.

For occasions of performance, see marok'an sarakuna.

masarta $\mathrm{p} 1$. (masarci m.s.)

Equivalent of marok'a. 
masartan hakimai pl. (masarcin hakimai m.s.) = masartan hakimi pl. (masarcin hakimi m.s.)

Equivalent of marok'an hakimai.

masartan sarakuna $\mathrm{pl}$. (masarcin sarakuna m.s.)

Equivalent of marok'an sarakuna.

masartan Sarki pl. (masarcin Sarki m.s.)

Term most commonly used in plural form as collective for royal marok'a; in Zaria it includes the court fool (wawa) and snake charmer (Sarkin Gardi), but in Katsina is objected to by the musicians themselves, who prefer marok'an Sarki.

See marok'an Sarki.

masu amshi pl. (mai amshi m.s.)

"yan amshi pl.('dan amshi m.s.)

= 'yan kar'bi p1. ('dan kar'bi m.s.)

$=$ masu amsawa $\mathrm{pl}$. (mai amsawa m.s.)

= 'yan amsawa p1. ('dan amsawa m.s.)

Members of response group in singing, drumming, trumpeting, etc.

masu kawo p1. (mai kawo m.s.)

A synonym for all sorts of drummers of membranophones. Kawo is the name of the wood (Afzelia africana) which is commonly used to make the bodyshell of drums.

mawak'a p1. (mawak'i m.s.)

= masu wak'a p1. (mai wak'a m.s.)

$=\underline{\text { sha'irai pl }}$. (sha'íi m.s.)

A collective term which embraces all sorts of male singers:

(i) professional male singers and/or composers; (ii) non-professional composers and/or singers of songs; (iii) poets, though they may be distinguished as masu rubuta wak'a p1. (mai rubuta wak'a m. or f.s.) or masu rubutu wak'a pl. mai rubutu 
wak'a m. or f.s.).

See wak'a.

mawak'a pl. (mawak'iya f.s.)

= zabiyoyi p1. (zabiya f.s. or zabaya f.s.)

(i) Any female professional singer.

(ii) Any female non-professional singer who may take the role of the solo singer for the singing of girls or women, but only used in connection with her performance and not as an indicator of her social status.

See mawak'a pl. (mawak'i m.s.)

shera m.s.

Marok'i who dresses and acts like a woman, joining groups of the latter in their songs and in performance of gu'da. Such activity is ridiculed by other marok'a.

yara pl. (yaro m.s.)

(i) Name commonly given to an apprentice musician who is often fed, lodged and taught by the head of his performance group.

(ii) Name of assistant drummers and/or members of vocal chorus in a performance group (e.g., yaron Caji).

zabiyoyi pl. (zabiya f.s. or zabaya f.s.)

$=$ marok'iya f.s.

(i) Professional female singers.

(ii) When married women wish to sing in their living quarters, one of their number may be elected "zabiya" for the singing, i.e., this woman temporarily assumes the role of a lead singer but not the social status of a professional.

See Zabiyar Sarki. 


\section{B. CLASSES OF PERFORMERS}

\section{Introduction}

\section{Notes on the Entries}

Entries will contain the following where applicable and/or where information is available:

(i) Name(s) of performers.

(ii) The letter indices opposite the names of performers are used as follows:

$\mathrm{cm}$ - court musicians and acclamators with official status whose patrons are Emirs, District Heads and other senior officials. Many of this class hold minor offices signified by titles (see Part C below).

$t$ - performers without official status, but tied, like court musicians, to a distinct class of patrons, e.g., musicians of farmers, hunters or blacksmiths.

fl - performers without official status, who are freelancers.

np - semi-professionals and non-professionals who are not considered by themselves or their audiences to be marok'a.

(iii) Instrument(s) played, ensemble combinations, and description of performance role.

(iv) Patrons of performers (cross-referenced).

(v) Venue of performance, if not apparent.

(vi) Occasion(s) of performance (cross-referenced only).

(vii) Oral 1iterature. Most entries are conventional jokes used between certain classes of performers. There are traditional joking relationships between kinsmen, ethnic groups, occupational 
groups and the inhabitants of different regions, people concerned in such relationships being termed abokan wasa. Here we will be concerned with an additional type: intra-occupational joking which may be termed wasa ("play") or wasan ba'a ("teasing"). Musicians tend to joke only with a class of musicians which they consider to be their equals or near-equals, and it most often takes place between drummers

(maka'da) and blowers of wind instruments (masu busa).

\section{Notes on Prefixes}

The name of most kinds of performers on musical instruments may be ascertained simply by adding the prefixes mai (singular) or masu (plural) to the name of the instrument. A less common alternative is to use the following prefixes plus the genitive link "n"; mai busa or mabusa (singular) and masu busa (plural) before the names of wind instruments; and maka'di or mai ki'da (singular) and maka'da or masu k'i'da (pluraI) before the names of most drums, string instruments and idiophones (e.g., mai busan sarewa, mai ki'dan goge, etc.).

Several instruments more often take the prefixes 'dan (singular) or 'yan (plura1), e.g.,' 'dan kazagi and 'yan kazagi or 'dan garura and yan garura.

Final1y, there is no reference to the instruments played in the names of certain classes of performers, chiefly professional singers (mawak'a or masu wak'a), professional acclamators (marok'an baki) and several kinds of

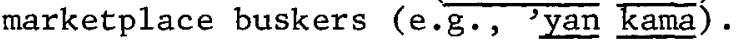


1) Masu ki'da ("drummers")

a. Idiophonists ("Drummers on idiophones")

karen Gusau m.s. ("dog of Gusau")

Musicians who play the agidigo while singing entertainment songs (wak'ar nasha'di), at naming and marriage ceremony feasts (buki) or prior to January 1966, political songs (wak'ar siyasa) at political party gatherings (Wasan N. $\overline{\text { P.C. Or }}$

N.E.P.U.). They often play in concert with masu kalangu and 'yan kuntuku Audu Karen Gusau is the best known of this comparatively small class of performers.

masu gora pl. (mai gora m.s.)

Shakers of a calabash rattle (caki or gora) who perform with masu garaya and marok'an baki for their patrons, the 'yan bori at bori ceremonies.

They also perform with masu molo.

masu kasam'bara p1. (mai kasam'bara m.s.)

Idiophonists who play kasam'bara in combination with the masu garaya and marok'an baki for their patrons, the ,yan bori at bori ceremonies. They are replaced in some ensemble combinations by masu gora. Masu kasam'bara also perform with masu molo.

masu ki'dan buta p1. (mai ki'dan buta m.s.)

Professional marok'a who perform especially for Koranic scholars and teachers (malamai). They are not to be confused with na buta. They provide rhythmic accompaniment for their songs and dances by shaking buta and beating them with rings on their fingers. They also slap their leather aprons (buzu) rhythmically while dancing, and just before they slap them they refer in song to the sheepskin rug (a1so buzu) that malamai sit on in their homes: 
Bari mu daki buzun malan

"Let, s slap the buzu of the malan."

They visit the malamai during the month of Ramadan (watan azumi) or during one of the annual religious feasts of $\mathrm{K}^{\prime}$ aramar Salla or Babbar Salla.

masu kuge pl. (mai kuge m.s.)

$\mathrm{cm}$

(i) Beaters of the double-belled iron gong, who play in concert with the Sarkin Kalangu of the Emir of Zaria when there is a wazan salla, or royal cavalcades: hawan kilisa; hawan daushe; hawan salla. It used to be played in war-time and in conjunction with the gangar fada, as well as with the kalangu. Until about 20 years ago the holders of the important sarauta titles of Madaki and Galadima owned kuge.

(ii) Beaters of kuge who play in combination with gangar noma and kazagi of the Sarkin Maka'dan Gangar Noma of the Emir of Zaria when playing for the hawan salla and for buki for the general public in villages. However, kuge combined with these instruments is not common, probably because it is viewed as an instrument of officialdom. See marok'an sarakuna, Sarkin Maka'da, marok'an Sarki.

'yan k'warya pl. ('dan k'warya m.s.)

(i) Drummers on k'waryar goge, who play in concert with masu goge. They are often apprentice goge players and also act as masu amshi ("the chor(1s").

(ii) Drummers on k'waryar kukuma who play in concert with masu kukuma and also act as either mawak'i ("solo singer") or masu amshi ("the chorus"). They are often apprentice kukuma players.

Wasa - masu kukuma to 'yan k'waryar goge:

Mu ba mu ki'dan k'warya da itace

"We (the kukuma ensemble) don't need sticks to beat k'warya."

See masu amada for 'yan k'warya f.p1. ('yar k'wa rya f.s.) 
'yan tandu p1. ('dan tandu m.s.)

$=\underline{\text { masu tandu }}$ pl. (mai tandu m.s.)

Performers who beat on large, leather bottles (tandu) while singing and doing a whirling dance in comical costumes. Their songs are humorous, lewd (gamtsi) and often contain zambo like those of 'yan gambara. They perform in harlots' houses, marketplaces or in any public place.

b. Drummers

karen marok'a ("dog of the marok'a")

$t$

A drummer-singer of very low rank who specializes in rok'o for marok'a, accompanying himself on kalangu. Dog-like, he barks in front of his patron's residence and acquires his gown by grabbing it with his teeth. He performs for his patrons at aure, suna, buki, tashen azumi and yawon salla. He also attends aure, suna and buki of the general public in the company of ordinary marok'a in order to receive a share of their profits.

In front of his patron's house, he drums, then barks and may sing the following:

Wane marok'i yau rok'o ya sami rok'o yau rok'o gidan marok'i idan rok'o da da'di yau ka ta, ba shi ka ji idan ma babu da'di yaut ka ta'ba shi ka ji abin da kake rok'o gidan wasu

yau ga shi an zo gidanka

"You particular marok'i, today rok'o meets rok'o, today rok'o is done at the house of a marok'i, if rok'o is enjoyable, you will experience it today and if it is not, a11 the same you will experience it today, today is your turn to give back what you (have received by) rok'o from other people's homes." 
maka'dan mai wasa da kura p1.

(maka'din mai wasa da kura m.s.)

$=$ maka'dan gardin kura pl.

(maka'din gardin kura m.s.)

Drummers for conjurers and wrestlers of hyenas (masu wasa da kura) who perform in the marketplace. They beat tallabe and, less often, gangar noma with kazagi.

karin magana:

Kura da shan bugu gardi da kar'be kur'di "The hyena receives the beating but his master receives the money."

maka'dan 'yan mata p1.

(maka'din 'yan mata m.s.)

$=$ masu gangar ,yan mata p1.

(mai gangar 'yan mata m.s.)

A generic term for drummers on kalangu and kwairama or occasionally on tallabe, who are sponsored chiefly by girls ('yan mata) and older boys and young men (samari). For performance occasions, see masu kalangu and masu kwairama. These drummers perform in concert with 'yan kazagi, 'yan kuntuku and marok'an baki.

maka'dan 'yan hoto $\mathrm{p} 1$.

(maka'din 'yan hoto m.s.)

Drummers on gangar noma and kazagi in accompaniment of dancing and exhibitions of strength by 'yan hoto. Performances include drumming the take of 'yan hoto on gangar noma and singing their praises, with the kazagi drummers acting as the chorus (masu amshi) and vocal acclamation (kirari) of their powers by marok'an baki.

maka'dan 'yan tauri pl.

(maka'din 'yan tauri m.s.)

$=$ masu ki' dan kufegere pl.

(mai ki'dan kufegere m.s.)

Praise singers and drummers of take on talle and sometimes on kalangu or gangar noma, who play only for their fellow 'yan tauri and do not consider themselves to be marok'a, though they receive 
payment for playing for their wasan 'yan tauri, buki and na'din sarauta. They also march annually in the hawan salla parade and special parades for V.I.P. (daba). Since many 'yan tauri are butchers, they perform at the butchers' boxing matches (dambe), turbannings (na'din sarauta) and drum in the market ( $\mathrm{ki}$ 'dan mahauta) for them before feast days.

Wasa - masu talle to Malamai:

Zo ka 'dauki ganga ka aje alk'alami

"Come and take the drum and put down the pen."

Malamai reply:

Za ka 'dauki alk'alami da takarda ka bar ganga?

"Will you take the pen and paper and leave the drum?"

masu banga pl. (mai banga m.s.)

Drummers on banga for an Emir or a senior official, who sing songs in praise (wak'ar yabo) of their patron or his associates. In Katsina and Zaria, the head of the ensemble (Magajin Banga) is the song leader (mawak'i), and the assistant drummers, some of whom hold lesser titles, act as chorus (masu amshi). See marok'an sarakuna for performance occasions. See also marok'an Sarki.

Wasa - masu algaita to masu banga:

Sai mun ga abin da kuke rufewa da wannan tsumma haka

"We must see what you are covering with the rags."

masu kotso to masu banga:

Mu ya'ya ne kullun muna gaba ku kuwa an tura ku baya

"We are smal1 children, always at the head of the procession -- while you are pushed to the rear*." (* reference to their traditional place in royal processions) 


\section{$\underline{\text { masu }}$ banga replies:}

Mu mun fiku gatanci tunda mu ana goyonmu ku kuwa sai a tura ku gaba ku kai ma zuma gidanta

"We are more favoured than you because we are always protected at the back while you are pushed forward to the hive* of the bees." ( $*$ reference to the drums they carry)

masu kotso to masu banga:

$\mathrm{Ku} \mathrm{kai}$ ma mai kalangu kuntukunshi

"Return the kuntuku* to its owner, mai kalangu." (* It looks like the banga but it is played by apprentices of 1ow-ranking kalangu drummers.)

masu duma pl. (mai duma m.s.)

Singers and drummers on duma.

karin magana:

'Dan kazagi ya fi mai duma 'doki

"The performer on kazagi surpasses the performer on duma in his eagerness," i.e., it is the lesser member of a partnership who

is the keenest.

masu duman girke p1.

(mai duman girke m.s.)

Singers and drummers on duman girke.

masu gangar algaita $\mathrm{pl}$.

$\mathrm{cm}$ (mai gangar algaita m.s.)

Singers and drummers on gangar algaita for a senior official, who play in ensemble with masu algaita in honour of their patron or his associates. The head of these drummers, as we11 as of the blowers of algaita, is usually the lead singer and given the title and office of Sarkin Maka'da. The other drummers act as the chorus (masu amshi) and some hold the lesser titles of Madakin Ki'da, Makaman $\mathrm{Ki}$ 'da, and Wazirin Ganga. For occasions of performance see marok'an sarakuna. 
masu gangar noma $\mathrm{pl}$.

(mai gangar $\overline{\text { noma }}$ m.s.)

Drummers of gangar noma, commonly encountered in Zaria, but rare in Katsina, who recognize farmers (manoma) as their traditional and primary patrons, though some -- Sarkin Maka'dan Gangar Noma -- play also for sarakuna or the performances of 'yan hoto and gardin kura. They drum a farmer's take at cooperative group work (gayya) and sing his praise (wak'ar yabo) at feasts (buki), with 'yan kazagi acting as the chorus (masu amshi) and the marok'an baki shouting their kirari. Masu gangar noma also perform at kalankuwa and rawan Gane. They used to drum regularly for girls, dancing (rawan 'yan mata) in rural communities but the masu kalangu and masu kwairama have, for the most part, replaced them in this role.

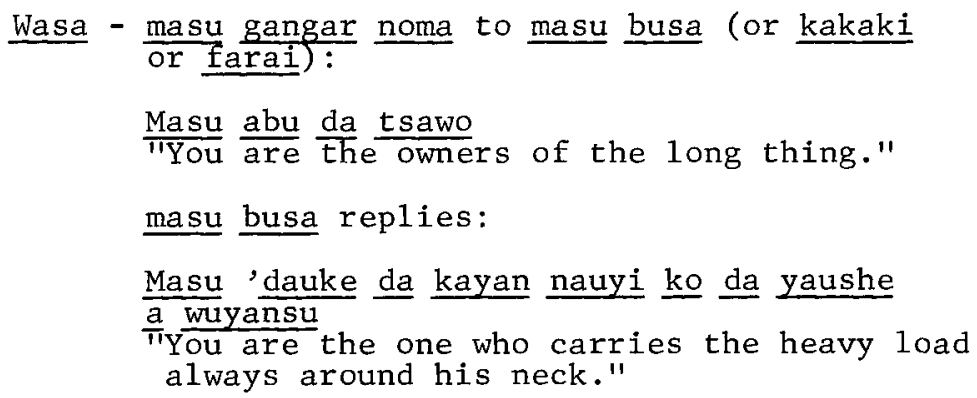

Masu abu da tsawo

"You are the owners of the long thing."

masu busa replies:

Masu 'dauke da kayan nauyi ko da yaushe "You are the one who carries the heavy load always around his neck."

masu gangar fada $\mathrm{p} 1$.

$\mathrm{cm}$

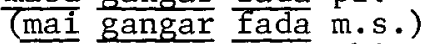

$=$ masu gangar saraki pl.

(mai gangar saraki m.s.)

Drummers on gangar fada for an Emir or a senior official, who play in his honour the take of his office and either sing (wak'ar yabo) or call

(kirari) his praises. The vocalist (mawak'i), if any, is the head of the ensemble (Sarkin Maka'da) and the other drummers, on some occasions, are the chorus (masu amshi). The masu gangar fada perform in a variety of ensembles. They play with a mai algaita (masu algaita) for the District Head of Kauru in Zaria, but they play alone for the District Head of Kajuru. The masu gangar fada of the Emir of Zaria combine in performance with masu $\mathrm{k}$ 'aho, masu farai, masu kakaki, the royal bamba' dawa and the $\underline{\text { San }}$ K'ira and his marok'an baki 
assistants. For the Emir of Katsina, the masu gangar fada perform with masu kakaki and masu Earai. See marok'an sarakuna for performance occasions.

Wasa - masu k'aho to masu gangar fada:

Kun 'dauko gidan zuma

"You carry around a beehive!"

masu jauje p1. (mai jauje m.s.)

$\mathrm{cm}$

Drummers on jauje and kolo for officialdom, who sing songs of praise (wak'ar yabo) and drum the take of their patron or his associates. The head of the ensemble (Sarkin Jauje) is the song leader (mawak'i), and the assistant drummers, some of whom have lesser titles, are the chorus (masu amshi). For performance occasions see marok an sarakuna. See a1so marok'an Sarki.

Wasa - masu busa (or any player of an aerophone for the Emir) to masu jauje:

Yaya kuka ji da tsarkiya da ta ke kama ku a hak'ark'ari

"How do you feel when the tsarkiya grabs your ribs?"

masu jauje replies:

$\mathrm{Ku}$ cikin ku ban da iska ba komai

"There is nothing in your stomach except air."

masu busa to masu jauje:

Kuna 'dauke da gidan zuma

"You are carrying a beehive."

masu kalangu pl. (mai kalangu m.s.)

$t / f 1$

masu ki'dan kalangu pl.

(mai ki $i^{\prime}$ dan kalangu m.s.)

A very large class of drummers who perform on

kalangu for: (i) butchers (mahauta), their traditional patrons; (ii) the youth (samari and 'yan mata); (iii) the general public, in the case of those who play in the bands of popular freelance singers, such as Alhaji Muhamman Shata. 
(i) Butchers: they drum their patron's take for naming and marriage feasts (buki), turbannings (na'din sarauta) and evening visitations during the month of Ramadan

(tashen azumi). They drum (k'dan fawa) to announce market slaughtering and to attract customers for their patrons, and as an accompaniment to playing with bulls (wasan hawan $k^{\prime}$ aho ) to encourage the sale of meat before a feast day, such as Sallar Cika Ciki. They also drum the take of boxers ('yan dambe), who are usual1y butchers.

(ii) Youth: the kalangu/'dan kar'bi drum set plus one or more kuntuku is used for youths' dancing, plays, ceremonies and sports. The kuntuku are played by 'yan kuntuku and the performing group also normally includes one or more marok'an baki. Usually in connection with buki they accompany the girls' dancing (rawan 'yan mata) and singing (wak'ar 'yan mata), and drum the take of both the girls and the young men at the dancing place. They also perform for kai gara and ajo for marriages, boxing (dambe), dancing of boys and young men (a sha k'afa) and various plays of the youth (wasan misisi and kwanta).

(iii) The general public: as above.

For other uses see Caji, 'yan gambara, masu kalangun Sarki, k'aramar kalangu and kalangun Sarki.

Wasa - masu goge to masu kalangu:

Ku sai 'yan mata kuna ta buge-buge suna jefa maku kwabo

"You only play for the girls to dance and give you pennies."

masu kalangu replies:

Ku sai karuwai suna maku rawa suna jefa taba ku k'arasa

"You only play for the harlots to dance and give you a half-smoked cigarette to finish up." 
masu kalangun Sarki p1.

$\mathrm{cm}$ (mai kalangun Sarki m.s.)

Drummers on kalangun Sarki and kolo, who drum take in honour of the Emir or his associates. They a1so occasionally perform in combination with a player of a double iron bell (masu kuge). For occasions of performance see marok'an sarakuna; however, they do not perform each week (waza) at the palace of the Emir of Zaria, as the other court musicians do.

masu kotso pl. (mai kotso m.s.)

$\mathrm{cm}$

Drummers on kotso for officialdom, who sing songs of praise (wak'ar yabo) and drum take for their patrons or their patrons' associates. The head of the ensemble (Magajin Kotso in Zaria; in Katsina, Sarkin Maka'dan Kotso) is the lead singer (mawak, $\vec{i})$, and the assistant drummers, some of whom have lesser titles, are the chorus (masu amshi). For performance occasions see ma rok'an sarakuna.

Wasa - masu algaita to masu kotso:

Ku cire daddawan tsohuwa da kuka namma a jiki

"Remove the locust bean cake* that you stick on your bodies (drums)." ( $*$ The locust bean cake stands for the nake on the membrane.)

masu kuru pl. (mai kuru m.s.)

As for masu gangar noma.

masu kurya pl. (ㅆi kurya m.s.) $\mathrm{cm}$

Drummers on kurya for an official of an Emir who perform take in honour of their patron or his associates (e.g., in Katsina by the musicians of Sarkin Karma who, himself the official of a district head, was traditionally in charge of the latter's infantry). In performance they may combine with one or more other masu kurya and masu kalangu, though the drum is more commonly used singly with kalangu, the main occasions being marriage and naming ceremonies of their patron and 
his family, and major festivals such as Babbar Salla and K'aramar Salla; they also drummed formerly in time of war to assemble the infantry and lead them into battle (see kirarin kurya, in Section I). The drum is also used by non-official freelance musicians in combination with duma and kazagi.

masu kwairama pl.

(mai kwairama m.s.)

= maka'dan 'yan mata p1.

(maka'din , yan mata m.s.)

$=$ masu gangar ,yan mata pl.

(mai gangar 'yan mata m.s.)

Drummers on kwairama in Zaria who perform solo or in combination with other masu kwairama and one or more 'yan kazagi, for the youth ('yan mata and samari). More often found in rural communities than in the cities, and in the former masu kalangu appear to be gradually superseding them. Some occasions in which they perform are rawan 'yan mata, buki, kai gara, kalankuwa, rawan Gane, a sha k'afa and kokawa. They drum the take of the youth and sing a variety of songs (wak'ar nasha'di, wak'ar yabo and wak'ar abayyana).

masu taushi pl. (mai taushi m.s.)

$=$ masu tabshi pl. (mai tabshi m.s.)

$\mathrm{cm}$

Singers and drummers on taushi for officialdom, who perform songs in praise (wak'ar yabo) of their patron or his associates. In Zaria and Katsina, the head of the ensemble (Sarkin Taushi) is the song leader (mawak'i) and the assistant drummers, some of whom have lesser titles, are the chorus (masu amshi). In Katsina, the chief taushi drummer for the Emir, Sarkin Tabshin Katsina Alhaji Mamman, is known throughout hausaland for his songs in praise of individuals and on national topics. For performance occasions, see marok'an sarakuna. See also marok'an Sarki.

masu tallabe pl. (mai tallabe m.s.)

Drummers on tallabe, who perform with 'yan gambara, na uwale and masu wasa da kura. A few have been observed druming for the singing and dancing of the youth (samari and 'yan mata). Professional 
tattoers ('yan jarfa) also use tallabe or smaller double-membraned drums like gangar algaita.

masu zambuna pl. (

Singers and drummers on zambuna unique to the office of Mara'din Kurfi in Katsina Emirate. Occasions and venues of performance are as for marok'an sarakuna.

'yan dundufa p1. ('dan dundufa m.s.)

$\mathrm{t}$

$=$ masu dundufa pl. (mai dundufa m.s.)

Singers and drummers on dundufa who sing praise songs (wak'ar yabo) in honour of their traditional patrons, the blacksmiths (mak'era), on such occasions as buki or na'din sarauta. They also greet the chief of their patrons, the Sarkin Mak'era, each Friday after prayers at the mosque (gaisuwar juma'a). There was only one family of 'yan dundufa performing in the emirate of Zaria in 1963-64, but at least four in Katsina Emirate in the same period.

'yan kashin kasuwa $=$ 'yan yabo

Persons who defecate in public or threaten to do so unless paid. They perform mainly in markets to musical accompaniment, kalangu or tallabe, and kazagi.

'yan kazagi p1. ('dan kazagi m.s.) flltt

Young men or boys, who can most often be found drumming kazagi in concert with masu gangar noma or masu kwairama, and singing the chorus refrains. They also perform with mawak'an Caji, 'yan gambara, masu wasa da kura, 'yan kashin kasuwa, and 'yan dundufa. They play the kazagi and perform as masu amshi while learning to play gangar noma, kwairama, and dundufa.

'yan kuntuku p1. ('dan kuntuku m.s.)

$=$ masu kurkutu pl. (mai kurkutu m.s.)

Boy drummers on kuntuku (kurkutu), who perform with masu kalangu for youths' dancing, ceremonies 
and games, as well as in the bands of such famous musicians as Alhaji Muhamman Shata, A1i 'Dan Saraki, etc. Young apprentices often play the kuntuku while learning to play the kalangu.

'yan tagaba pl. ('dan tagaba m.s.)

= masu rok'o da kuka pl.

(mai rok'o da kuka m.s.)

Professional cadgers who say "If you don't give me something I'll cry" and tell exceedingly sad, hard-luck stories. They accompany themselves on kalangu and are usually found in the market place. Non-professional cadgers who do not drum with their "performance" may also be referred to by the same term.

yaran Caji pl. (yaron Caji m.s.)

Members of a Caji performance group under a leader and singer such as the famous Hamza Caji or Ibrahim 'Dan Mani Caji. As such, they act as both drummer on gangar Caji, kazagi or k'aramar kalangu, and as member of the vocal chorus (masu amshi).

c. Lutenists ("Drummers on chordophones")

$\underline{\text { masu garaya }}$ pl. (mai garaya m.s.) t/f1

Any performers on garaya, the instrument which was originally played in honour of hunters, but today, in view of the decrease in the numbers of the latter, is increasingly used for other types of music (see kirarin mai garaya, below). Those who perform for hunters in Zaria, play the large garaya (komo or babbar garaya) and prefer to be called masu komo, though the general public does not make this distinction. Performers on the garaya -usually the smaller type -- may also accompany spirit possession dancers at bori ceremonies, which are normally held in harlots, houses. Masu garayar bori, as such specialists are called, also sing songs in praise of bori spirits (wak'ar bori) and of some of the spectators. They perform with one or more masu gora or masu kasam'bara and one or more marok’an baki. Masu garayar bori may also 
play for buki and some have become freelance musicians who perform wak'ar nasha'di for the general public.

kirarin mai garaya (kirari for a garaya player):

Inda ba mahalbi mai garaya ma mahalbi ne

"When there is no hunter, the garaya player becomes the hunter (for'patronage)."

Wasa - masu goge to masu garaya:

$\mathrm{Za}$ mu yi k'aran ku wajen Maguzawa sabo da

kun hana musu cin fatan gafiya kun 'dauka kun dunka garaya da shi

"We shall report you to the Maguzawa (pagan Hausa), because you have prevented them from eating the skin of the bandicoot by using it to make garaya."

Wasa - masu kukuma to masu garayar bori:

Mu namu ki'dan ba ma yin ki'dan bori da shi balle a yi rawa

"As for our drumming, it's certainly not for bori let alone dancing."

masu garaya reply:

Ai mu namu tsarkiyar biyu ne don haka muke ki , dan bor $i$ da shi a yi ta nisha, di

"Ours always has two strings and that is why we do bori drumming and give so much pleasure."

masu goge pl. (mai goge m.s.)

Performer on goge in concert with 'yan $\mathrm{k}^{\text {'waryar }}$ goge and marok'an baki for the following occasions and patrons: (i) the activities of political parties (wasan N.P.C. or N.E.P.U. and rawan kashewa) until January 1966 . See wak'ar siyasa; (ii) prominent persons, whether members of officialdom, politicians, or wealthy merchants. See wak'ar yabo; (iii) 'yan bori for bori ceremonies. See wak'ar bori; (iv) ajo ceremonies to raise money, normal1y to help the bridegroom meet marriage expenses; (v) the dancing of harlots and praise in song (wak'ar yabo) and speech (kirari) of harlots and their patrons. 


\section{Wasa - masu garaya to masu goge:}

$\underline{\mathrm{Za}}$ mu kar'be gogenku mu ba zuma ya yi sak'a $\frac{z a}{a} \frac{\overline{i k} i}{i k}$

"We will seize your goge and give it to the bees to put their hive in." (Note: reference to hole in calabash resonator like hole in beehive.)

masu garaya to masu goge:

Adabo-adabo* mai goge ya ga farkansa

(* adabo d.f. Yoruba odabo)

"Good-bye, good-bye, mai goge sees his girlfriend."

masu gurmi pl. (mai gurmi m.s.)

Performers on gurmi who traditionally played and sang in honour of 'yan kokuwa, but are today a vanishing class of musician.

masu komo $\mathrm{pl}$. (mai komo m.s.)

Performing solo or in a group they sing praise songs (wak'ar yabo) for their traditional patrons, the hunters (maharba), accompanying themselves on the lute (komo or babbar garaya). They perform for hunters' feasts (buki), turbannings (na'din sarauta), big hunts (bago), and they march with their patrons in the annual feast-day processions (hawan salla and hawan daushe).

Wasa - masu gangar noma to masu komo:

Ku lik'e wannan ramin, mu gani ko ya yi k'ara

"B1ock up that hole (in your komo) and let's see if it still wails."

masu komo reply:

Ku kwance tsarkiyar ku buga mu gani in zai yi k'ara

"Loosen your tsarkiya and drum and let's see if it will still wail."

See masu garaya. 
masu kukuma pl. (mai kukuma m.s.)

$\mathrm{f} 1 / \mathrm{np}$

Marok'a who perform on kukuma and/or sing (wak'ar nasha'di, wak'ar yabo, wak'ar siyasa and bege) for the general public in combination with 'yan $k$ 'warya, who beat $k$ 'waryar kukuma. They most often perform for wealthy merchants (attajirai), officialdom (sarakuna), and for harlots and their patrons. Some also perform at political party functions, ajo, buki and kalankuwa celebrations. Nonmarok' a (young men and women, and married women) also play kukuma for pleasure.

Wasa - masu kukuma to masu goge:

Kukuma ba ta kukan kura ba ta kukan jaki "The kukuma does not cry like a hyena but like a jackass."

masu kukuma to 'yan kuntigi:

Naku ba shi da k'ara kamar namar namu dom ba za'a ji a nesa ba

"Yours doesn, $t$ wail with a body of sound like ours because it can't be heard from afar."

'yan kuntigi reply:

Mu namu ko a ina ya kama sai mu yi don a aljihu muke tafe da shi

"Ours can be played anywhere because we carry it in our pocket."

masu molo p1. (mai molo m.s.)

Male singers of songs of entertainment and praise (wak'ar nasha'di and wak'ar yabo) who accompany themselves on the three-stringed plucked lute (molo). They perform solo or in combination with masu kasam'bara or masu gora for the general pubIic and for harlots and their patrons. Like the kukuma and kuntigi, the molo is also played by non-professionals for their own pleasure.

\section{'yan kuntigi pl. ('dan kuntigi m.s.) $\quad$ fl/np}

Male or, less often, female solo singers of various types of song, e.g., songs of entertainment (wak'ar nasha'di), political songs (wak'ar siyasa), 
and praise songs (wak'ar yabo), who accompany themselves on a single-stringed plucked lute (kuntigi). Made popular as an accompaniment instrument by the artistry of such singers as 'Dan Maraya and Mai Kur'di 'Dan Duna. Such performers play for wedding and naming feasts (buki) of Emirs, senior officials and wealthy merchants, and, prior to January 1966, entertained at political party gatherings (wasan N.P.C. or N.E.P.U.). other performers play more often for lorry drivers in carparks, gamblers and harlots. Like the kukuma and the molo, the kuntigi is also played by non-professionals for the $\overline{i r}$ own pleasure.

\author{
Wasa - Caji singer to 'yan kuntigi: \\ Mu ba mu yin ki'dan gwangwani \\ "We are not playing a small tin can." \\ 'yan kuntigi reply: \\ Mu ba ruwanmu da kwaramniya \\ "We are not concerned with so much noise."
}

2) Masu busa ("blowers")

masu algaita p1. (mai algaita m.s.)

$\mathrm{cm}$

Blowers of the double reed pipe (algaita) of a senior official but not of the Emir in Katsina and Zaria. Solo or in ensemble, take are performed in honour of the official, which are normally synchronized with songs of praise (wak'ar yabo) sung by the leader of the group, the Sarkin Maka'da and his chorus, the masu gangar algaita. Senior players of the algaita often hold the title and office of Magajin Busa and assistant algaita players sometimes have lesser titles. Masu algaita also perform in combination with masu kakaki, masu farai and masu gangar fada. For performance occasions see marok'an sarakuna.

Wasa - masu kotso to masu algaita:

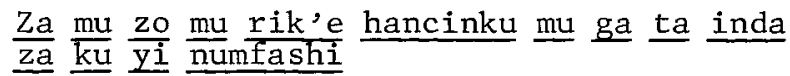




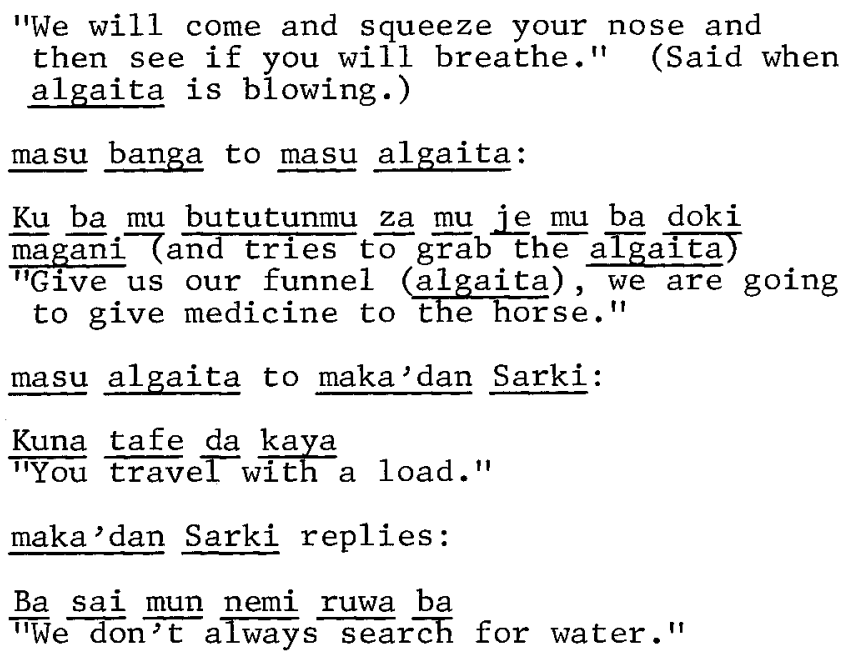

masu busan til'boro $\mathrm{p} 1$. $\mathrm{np} / \mathrm{fl}$ (mai busan til'boro m.s.)

Young men who blow til'boro for their peers in accompaniment of dance, acclamation and song. They perform after the farming season and during watan azumi. They are semi-professional and are not considered marok'a. Others, particularly smal1 boys, blow til'boro solely for their own amusement.

masu farai p1. (mai farai m.s.) $\mathrm{cm}$

Blowers of wooden 1ip-vibrated trumpet (farai) of the Emirs of Zaria and Katsina, though in Zaria, in former times, high officials with titles of Waziri and Madaki had masu farai of their own; in Katsina, however, the instrument appears to be of comparatively recent introduction. Masu farai perform in combination with masu k'aho, masu kakaki and masu gangar fada, $\overline{\text { and }}$ they more or less synchronize the take they blow with those played by the other musicians at, for example, a fanfare (waza) performed in honour of their patron every Thursday evening. In Katsina, the head of the masu farai has the title and office of Sarkin Farai, but in Zaria he is called the Magajin Busa and is number two in the rank hierarchy. The Magajin Busa performs solo daily in front of the Emir's palace, blowing the take and sometimes 
shouting the kirari of approaching officials to notify the Emir of their arrival, and he accompanies the Emir on official business trips by auto, blowing his trumpet to notify the people of the Emir's arrival. For additional performance occasions, see marok'an sarakuna.

Wasa - masu gangar noma to masu farai:

Me ya sa ba ku hurawa ba tare da kun sa ruwa ba? Kuna 'dauke da kwarkwaro ne? "Why is it you don't blow unless you've poured water? Are you carrying a funnel?"

masu farai replies:

Ku kuma mu zuba k'asa mu ga wanda zai "As for you, 1et's fill our instruments with sand and see who can carry it."

masu k'aho p1. (mai k'aho m.s.)

$\mathrm{cm} / \mathrm{f} 1$

(i) Blowers of the side-blown, roan antelope horn ( $k$ 'aho) of the Emir of Zaria. In former times the Waziri of Zaria, second in rank to the Emirr, and the Fagaci, a District Head, had masu $k$ 'aho of their own. The head of the royal musicians, the Sarkin Busa, blows the $k$ 'aho and as the Emir's chief musician, he is considered the head of all of the musicians of the emirate. The Sarkin Busa performs solo daily in front of the Emir's Council Chamber, blowing the take of each approaching senior official to notify the Emir of the arrival. He performs with one or more masu $k$ 'aho in concert with masu kakaki, masu farai and masu gangar fada for royal fanfares in honour of the Emir held, for example, on Thursday evenings (waza). On these occasions the take played by each class of performers is more or less synchronized with those blown by the masu $\mathrm{k}$ 'aho. For other occasions of performance see marok'an sarakuna.

(ii) A smaller horn of a gazelle (k'ahon tsauri) is blown by non-official professional musicians in rural communities for such occasions as kalankuwa, wasan 'yan tauri, and 

rawan Gane. They perform together with
masu gangar noma and 'yan kazagi.

It should be noted that the wawa, the court fool, of the Emir of Zaria carries a large $k$ 'aho like that of the Sarkin Busa, but he does not play more than one tone on it or attempt to play take, i.e., he simply toots it once or twice when the Emir makes an appearance.

Wasa - Sarkin Maka'da to Sarkin Busa:

$\mathrm{Ka}$ 'dauko $\mathrm{k}$ 'ahon sa ne?

"You are bringing an ox horn?"

masu gangar fada to masu k'aho:

Ba ku zuwa gari sai da k'uk'umi

TYou never enter a town unless you are tied (like a slave or prisoner)."* $(*$ a reference to the playing position of the masu k'aho)

masu kakaki pl. (mai kakaki m.s.)

cm

Blowers of the long metal trumpet (kakaki) of an

Emir and more rarely, as in Zaria, of a few senior officials: the Galadiman Zazzau and the Sarkin

Kauru. In Katsina the previous Emir, Alhaji

Muhamman Dikko, gave a kakaki to Sarkin Musawa, a

District Head of whom he was very fond, but such

an action has never since been repeated. In Zaria

the head of the masu kakaki holds the title and office of Sarkin Kakaki, in Katsina he holds the title and office of Sarkin Busa, while in both places some of the others have lesser titles. He blows the take of his patron's office, solo or with one or more masu kakaki in a leader and chorus response style. Different combinations of the following perform with masu kakaki: masu farai; masu k'aho; masu gangar fada; bamba'dawa; and the roya 1 marok'an baki. In general, the most frequent occasion for their use is the weekly sara (= waza) on Thursday evenings, other occasions being the turbanning of officials and, in Katsina, performances solicited by an official after the weekly sara. Uniquely, perhaps, the Sarkin Kakaki of the $\overline{\text { Emir }}$ of Zaria performs solo with the royal tambura from time to time and every morning at dawn he climbs up on a rock outcrop near the palace and blows take honouring his patron and 
greeting the people at the beginning of a new day. For other occasions of performance see marok'an sarakuna.

Wasa - masu gangar fada to masu kakaki:

Abinka da tsawo

"Your thing is very long!"

masu kakaki to masu gangar fada:

Ai arziki ne?

"Surely it is wealth?"

masu kakaki to the maka'da:

Idan ana ruwa kowa ya fita da kayan

sana , anshi mu ga wanda zai jik'e

"When it is raining and everyone goes out with the tools of his trade, we will see which one gets soaked."

masu jauje to masu kakaki:

Kuna tafe da dogon gwangwala na zunguro dabino

"You are carrying a stick for knocking down date nuts."

masu sarewa $\mathrm{pl}$.

(mai sarewa m.s.)

$\mathrm{np} / \mathrm{f1}$

Blowers of sarewa, both professionals and nonprofessionals.

'yan dama1go

('dan damalgo m.s.)

$\mathrm{np} / \mathrm{fl}$

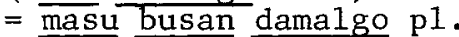

(mai busan damalgo m.s.)

Damalgo blowers, singers and dancers who perform in the streets during the month of Ramadan (watan azumi) for the general public. They are semiprofessionals who receive a little money for performing, but are not considered marok'a. 
3) Mawak'a ("singers")

masu amada p1. (mai amada m.s.)

(mawak'in amada m.s.)

Professional female singers (zabiya) who perform especially for women at buki in the women's quarters. Songs (wak'ar nasha'di, wak'ar siyasa and wak'ar yabo) are sung in the amada style (ki'dan amada), a singer either accompanying herself on a calabash drum ( $k$ 'warya) or a set of calabash drums ( $k$ 'waryar $\mathrm{ki}$ 'dan ruwa) played by the singer and her chorus ('yan k'warya f.pl., 'yar k'warya f.s.). Songs ridiculing co-wives are especially popular (wak'ar kishiya). The 'yan k'warya are either professionals or non-professionals, usually the latter.

mawak'an bege $\mathrm{pl}$.

(mawak'in bege m.s.)

$\mathrm{cm} / \mathrm{np}$

Professional unaccompanied "singers" of religious poems nostalgically praising the Prophet (see bege and wak'a). It should be noted that there is a separate class of blind beggars who similarly praise the Prophet but are not viewed as marok'a. They are thought to bring good fortune to their donors and some, like Malan Aliyu Namangi of Zaria, have become revered poets and scholars, who are called masu bege. Malan Aliyu has set some of his religious poems to $\overline{\mathrm{Caji}}$ drum rhythms and performs them over the radio.

mawak'an Caji pl.

f1 (mawak'in Caji m.s.)

Popular singers and heads of bands which play the Caji style of music, which was originated by Hamza Caji of Kano. Caji singers, known for the clever lyrics of their songs (wak'ar nasha'di and wak'ar yabo) and their style of drumming (ki'dan Caji), travel much of the time with their bands, playing especially for officialdom (sarakuna) and wealthy merchants (attajirai), on such occasions as buki, tashen azumi and yawon salla. The instruments 
used in Caji bands are the gangar Caji, kalangu and kazagi and they are performed upon by yaron Caji, who also perform as the vocal chorus.

mawak'an kukuma p1. (mawak'in kukuma m.s.)

Lead singers and often the heads of kukuma bands who may or may not play the kukuma. See masu kukuma for patrons and performance occasions.

mawak'an Hamisu pl.

(mawak'in Hamisu m.s.)

$\mathrm{fI} / \mathrm{cm}$

Singers in Hamisu style who accompany themselves on ganga, in combination with one or more players of ganga and kazagi, who sing the vocal responses. Mawak'an Hamisu sing wak'ar yabo and wak'ar nasha'di for the general public, especially for attajirai and other wealthy persons. In Zaria, one such singer and his band are court musicians of a District Head. The Hamisu style was made popular by the artistry of Hamisu Na Biyar.

mawak'an Shata $\mathrm{p} 1$.

Professional male singers who imitate the style and voice quality of Alhaji Muhamman Shata, the most famous and successful of all present-day singers. The term is, however, frequently used derogatively, implying the singer has no talent of his own.

mawak'an 'yan mata $\mathrm{p} 1$.

(mawak'in 'yan mata m.s.)

Several male professional singers in Zaria City who are the song leaders of the girls' chorus, singing in a falsetto voice and dancing from time to time, to rhythms of kalangu, 'dan kar'bi and kuntuku. They are in demand for such occasions as buki, wasan misisi and kwanta. They also do tashen azumi and sing wak'ar abayyana for the annual rawan Gane. See masu kalangu. 
Professional comedians who sing (wak'ar gamtsi) and/or talk and dance humorously and lewdly in marketplaces, stripped to the waist and dressed in huge baggy trousers (buje) and long red hats (dara). Others paint their faces blue or with charcoal and wear enormous turbans and ride donkeys in turbanning processions. They do acrobatics, imitations (e.g., of 'yan tauri) and make funny faces. They are accompanied by marok'a playing tallabe, kalangu, kazagi or damalgo. Have been observed performing with 'yan gambara. See 'yan kama.

'yan daji pl. ('dan daji m.s.)

Do tashe during watan azumi, dressed in gowns made of old mats with many pieces of metal and calabash attached to them. Sing and dance humorously, providing own rhythmic accompaniment by beating ruwan gatari against ruwan patenya.

\section{'yan kama pl. ('dan kama m.s.)}

Considered by many the funniest of the Hausa comedians (cf. na uwale, masu tandu, 'yan gambara and 'yan galura). They perform individually or in groups of up to five, catching gifts of money and kola-nuts in their mouths, and accompanying their songs and acts on kazagi in many areas and on gangar 'yan kama in Zaria. They wear funny hats, carry wooden swords and a calabash dipper used for cooking which they attach to a string of prayer beads. Reference to food is a central theme in their humour, e.g., in comic recitations of prayers and readings from the Koran, and in the titles they assign themselves, like "Minister of the Kitchen" or "Brave Man of Porridge." They do comic imitations of 'yan tauri, 'yan hoto and popular singers, for example, Shata. When imitating the dancing and spirit possession of 'yan bori, they blow through the open end of their drums to make a sound like goge, which is played for bori. They perform in daylight in markets, on the streets and at the homes of sarakuna, attajirai and harlots. They make extensive annual tours just after the harvest and later, during the hot season (cin rani). See 'yankamanci. 
$\underline{\text { Zabiyar }}$ Sarki $=\underline{\text { Zabayar }}$ Sarki

A professional singer of praise songs for an Emir at the waza and buki of his wives, and for all of the royal cavalcades (hawan salla, hawan daushe, and hawan kilisa). She sings every day while escorting the Emir from the wives' quarter of the palace to the Council Chamber and back again. This was not a title requiring a turbanning (na'din sarauta) and the post is now vacant in Zaria. At the court of the Emir of Katsina the post is filled. See zabiya, marok'an sarakuna, and marok'an Sarki.

4) Marok'an baki ("acclamators")

bamba'dawa pl. (babam'bade m.s.)

$\mathrm{cm} / \mathrm{fl}$

= bamba'de m.s., bamba'do m.s.)

Professional panegyrists who traditionally praise in the Fulani language (and still do in Zaria), as opposed to other sorts of marok'an baki who perform in Hausa. Their vocalized acclamations are performed in a high, rather singsong, falsettolike voice, and they do not play musical instruments, though they may combine in performance with instrumentalists. The performance of their craft is called bamba'danci. Their patrons are chiefly Fulani officials; however, they do bamba'danci from time to time at buki of other settled Fulani and at the camps of the cattle-herding Fulani. Bamba'dawa are assigned a higher place in the hierarchy of rank of the royal musicians than the marok'an baki, due to their association with the Fulani heritage of much of the senior officialdom. The head of the royal bamba'dawa of the Emir of Zaria, the Sarkin Bamba'dawa is not only senior to the head of the marok'an baki, the San K'ira, but has the right to appoint his successor. The Sarkin Bamba'dawa and his assistants perform on such occasions as Thursday evening waza, turbannings (na'din sarauta) and, ideally, each morning in front of the palace. For other occasions of performance see marok'an sarakuna and marok'an Sarki. 
kaskar karen marok'a f.s.

("tick of the dog of the marok'a")

An acclamator (marok'in baki) who specializes in rok'o of karen marok'a. "Tick-1ike," he sticks close to the karen marok'a to receive a share of his earnings.

marok'an baki pl. $\mathrm{E} 1 / \mathrm{cm}$

(marok'in baki m.s.)

='yan k'ira p1. ('dan k'ira m.s.)

$=$ San K'ira m.s.

$=$ masu kirari p1. (mai kirari m.s.)

$=$ 'yan ma'abba pl.

('dan ma'abba or ma'abba m.s.)

Professional acclamators, any marok'a who shout laudatory epthets (kirari) in the Hausa language (cf. bamba'dawa) but do not sing or play a musical instrument, though they often combine in performance with instrumentalists. Some are court panegyrists for officialdom, but most are freelance performers for the general public, on such occasions as aure, suna, buki, na'din sarauta, tashen azumi, rawan 'yan mata, wasan misisi, kwanta, dambe, kokawa, bori, ajo, gayya, kalankuwa, rawan kashewa, and rawan Gane. See bamba'dawa, San K'ira,' 'yan agalanda, kaskar karen marok'a and mawak'an bodo.

mawak'an bodo pl.

(mawak'in bodo m.s.)

$\mathrm{fl} / \mathrm{cm}$

Marok'an baki in Zaria who do acclamation in a high singsong voice like bamba'dawa but in the Hausa language; a comparatively rare style of acclamation which is said to be dying out. Two of them in Zaria are marok'a of a high official.

$\underline{\text { San }}$ K'ira m.s.

$\mathrm{cm} / \mathrm{f} 1$

(i) Any marok'in baki.

(ii) The title of the chief of the marok'an baki for officialdom, e.g., San K'iran Sarkin Zazzau ("San K'ira of the Emir of Zaria"). 
'yan agalanda $\mathrm{pl}$.

Marok'an baki who call the praises of youth at boxing (dambe), wrestling matches (kokawa) and farmwork bees (gayya).

5) 'Yan magana ("talkers")

'yan gambara $\mathrm{p} 1$.

('dan gambara m.s., gugurugu m.s.)

Professional satirists who perform mainly in markets, using metric speech for recitations containing considerable gamtsi and zambo (See gambara, Section V, 2.542.). They accompany themselves on gambara (= tallabe) and their bands may also number additional tallabe players, plus one or more masu kalangu, 'yan kazagi and marok'an baki. They also perform for the feasts (buki) of wealthy and generous persons, turbannings (na'din sarauta) of high officials, and at harlots, houses at night.

'yan garura pl. ('dan garura m.s.)

='yan galura p1. ('dan galura m.s.)

$\mathrm{f} 1 / \mathrm{cm}$

$=$ 'yan kacikaura $\mathrm{p} 1$.

('dan kacikaura m.s.)

$=\underline{\text { Malan Na Buta }} \mathrm{m} . \mathrm{s} .=$ na buta $\mathrm{m} . \mathrm{s}$.

A large class of professional comedian-acclamators who speak rapidly and rhythmically or occasionally sing while accompanying themselves with a handheld rattle called buta or galura. Like 'yan gambara, they praise their sponsors and castigate their sponsors, enemies in a particularly bawdy and amusing fashion. Some also dance lewdly while stripped to the waist. They most often perform in markets for wealthy traders and merchants and their clientele and they are reputed for quickly turning their praise to ridicule (zambo) when gifts are not forthcoming. Many also perform regularly for officialdom and a few have received titles from them, e.g., Sarkin Buta and Wazirin Buta. Prior to January 1966, some also performed at political party gatherings (wasan N.P.C. or N.E.P.U.). 
Wasa - 'dan gambara to na buta:

Ba buta ba ko randa ne ba yai nama haka ba "Neither a pot nor a kettle can do this to us."

na buta reply:

Ba gambara ba ko dunhun sak'i ne ba kai mana haka ba

"Neither a Iancy cloth nor a plain one can do this to us."

'yan kacikaura p1.

'dan kacikaura m.s.)

A synonym for 'yan garura or na buta in Zaria. In Katsina, where the term is commonly used, they accompany themselves with a different type of rattle called kacikaura.

\section{'yan magana}

Marok' $i$ who talk rapidly and rhythmically, praising or ridiculing persons. Occasionally accompany talk with rattle like na buta.

\section{OFFICES AND TITLES OF PERFORMERS}

\section{Introduction}

Court musicians and acclamators, in particular, are often addressed or referred to by titie of office. Office or position (sarauta) is signified by a title and a ceremonial turbanning (na'din sarauta) at the hands of the dispensing authority. Certain titles are used repeatedly from top to bottom of Hausa society. Though musicians and acclamators enjoy comparatively low rank, those who are clients of officialdom often hold titles similar to their high-ranking patrons, e.g., Sarki, Waziri, Galadima, Magaji, Ciroma, 'Dan Galadima, Sarkin Fada, Turaki, etc., 
though, of course, they may be differentiated by additional terms, as in Sarkin Maka'da or Wazirin Banga. The full title of a performer would include the title of his patron, e.g., the head of the masu banga, the Magajin Banga, of the Galadima of Zazzau (Zaria) would have the full title of Magajin Bangan Galadiman Zazzau. These complete titles are rarely used and are not included here.

Though titles are much more common among court musicians of officialdom than among musicians of the general public, not all court musicians (particularly assistant) have titles. These are usually named by the addition of the prefixes mai (sing.) and masu ( 1. ) to the name of their instruments, e.g., mai banga or masu banga. Some non-court musicians have been turbanned by officialdom and hold titles, e.g., Sarkin Maka'da, and they are usually found among drummers of farmers (masu gangar noma) and drummers of butchers (masu kalangu). In addition, some heads among court musicians have "acting" titles, i.e., they have not yet been turbanned, usually because they have not accumulated enough wealth to do so. Among other kinds of musicians, one occasionally encounters a musician who has a self-appointed office and title, though the public is aware that they have not been properly installed in office.

Some court musicians move with their patron when he is promoted to a new sarauta, but most prefer to continue to reside in the same place under their patron's successor. The titles of officialdom and musicians of Zaria are those current in 1963-64; the titles of the official musicians of the court of the Emir of Katsina are those current in 1965 .

\section{Bikon Tambari}

Head of tambari drummers of the Emir of Abuja, a non-professional. See Sarkin Tambari, Tambura, Magajin Tambari.

\section{Magajin Banga}

1. Head of masu banga of the Emirs of Katsina and Zaria. The principal assistant of these heads has the sarauta title of Madakin Banga.

2. Head of masu banga of the Galadima, a high senior official resident in Zaria City. 
3. Head of masu banga of the District Heads of Ikara, zangon Katab, Soba, Lere, Sabon Gari, Kubau, and Zaria City. The head of masu banga of the District Head of Kauru atypically has the tit1e of Galadiman Banga. Sarauta titles of assistant masu banga of several District Heads: Madakin Banga; Wazirin Banga; Galadiman Banga; and Ciroman Banga.

See marok'an Sarki, marok'an sarakuna.

\section{Magajin Busa}

1. Head of masu farai of the Emir of Zaria.

2. Senior masu algaita of several District Heads in Zaria; however, the head of the performing ensemble -- composed of masu gangar algaita as well as masu algaita - - often holds the sarauta title of Sarkin Maka'da. Lesser sarauta titles held by masu algaita are Madakin Busa, Turakin Busa and Ma'ajin Busa.

\section{Magajin Kotso}

Head of masu kotso of the District Heads of Kubau and Igabi in Zaria. The sarauta title of a principal assistant of the Magajin Kotso at Kubau is Wazirin Kotso. See Sarkin Maka'dan Kotso.

\section{$\underline{\text { San }} \underline{K^{\prime} \text { ira }}$}

1. Chief of the marok'an baki for officialdom.

2. The head of the royal marok'an baki of the Emir of Zaria, San K'iran Zazzau, whose assistants hold the following lesser titles: Wazirin Rok'o; Madakin Rok'o; Galadiman Rok'o; Sarkin Fadan San K'iran Zazzau; and Wakilin Rok'o.

See marok'an Sarki.

\section{Sarkin Bamba'dawa}

Head of bamba'dawa in Katsina and Zaria. The assistants of the Sarkin Bamba'dawa of the Emir of Zaria hold the following lesser sarauta titles: 
Dunkan Bamba'dawa; 'Dan Galadiman Bamba'dawa; and Ciroman Bamba'dawa. See marok'an Sarki.

\section{$\underline{\text { Sarkin Busa }}$}

1. Head of masu $k$ 'aho of the Emir of Zaria, who is also chief of all royal marok'a (marok'an Sarki) and, by extension, all marok'a in the emirate.

2. Head of royal masu kakaki in Katsina. His principal assistant previousiy held the sarauta title of 'Dan Home.

\section{Sarkin Buta}

Head of na buta (= 'yan garura) of the District Head of Sabon Gari of Zaria City. The sarauta title of his principal assistant is Wazirin Buta. See marok'an sarakuna.

\section{$\underline{\text { Sarkin }}$ Farai}

Head of masu farai in Katsina.

\section{Sarkin Gardi}

Head of the Emir of Zaria's snake-charmers; who is reckoned as one of masartan Sarki. His principal assistant has the sarauta title of Madakin Gardi.

\section{Sarkin Goge}

Heads of masu goge in Zaria City.

1. One such sarauta title-holder, Sarkin Gogen Tudun Wada, was turbanned by his principal patron, the Chief of the Strangers' Quarter (Sarkin Tudun Wada) .

2. Two others with the title, Sarkin Gogen N.P.C., were clients and regular performers for the local political party organizations of the Northern People's Congress. 
PERFORMERS / 101

$\underline{\text { Sarkin Jauje }}$

1. Head of masu jauje of the Emir of Zaria. His principal assistant has the sarauta title of Madakin Jauje.

2. Head of masu jauje of the District Heads of Ikara, Kacia and Kauru. Lesser sarauta titles of assistants of the head at Kacia are Madakin Jauje and Ciroman Jauje.

See marok'an Sarki, marok'an sarakuna.

$\underline{\text { Sarkin Kakaki }}$

Head of masu kakaki of the following officials in Zaria:

1. Sarkin Zazzau, the Emir of Zaria. The principal assistant of the Emir's Sarkin Kakaki has the sarauta title of Madakin Kakaki.

2. Galadiman Zazzau, a very high official under the Emir.

3. Sarkin Kauru (District Head of a former vassal kingdom).

See Sarkin Busa, marok'an Sarki.

\section{Sarkin Kalangu}

Head of masu kalangun Sarki of the Emir of Zaria. In 1964 this position was filled by an acting head who had not been turbanned. See marok'an Sarki.

Sarkin Ki'dan Caji

Sarauta title of a Caji singer turbanned by his patron, the District Head of Sabon Gari in Zaria.

Normally such freelance singers are not turbanned.

See mawak'an $\mathrm{Caji}$, yaron $\mathrm{Caji}$ and marok'an sarakuna.

Sarkin Maka'da

1. Head of royal marok'a in Katsina. 
2. Head of masu gangar fada of the Emirs of Zaria and Katsina. The sarauta title of their principal assistant is Madakin $\mathrm{Ki}$ 'da in Zaria and Wazirin Ki'da in Katsina.

3. Head of masu gangar fada of District Heads of former vassal states (Kajuru and Kauru) in Zaria. Lesser sarauta titles of assistants of the Head at Kajuru: Madakin Ki'da; Turakin Ki'da ; 'Dan Galadiman $\mathrm{Ki}^{\text {'da. }}$

4. Head and usually lead singer of a band composed of masu algaita and masu gangar algaita of Zaria District Heads of Ikara, Zangon Katab, Giwa, Makarfi, Lere, Zaria City and environs. Lesser sarauta titles of assistant masu gangan algaita of Heads at Lere and Giwa: Madak'in Ki, Makaman Ki'da and Wazirin Ganga. The latter title is also held by a mai gangar algaita of the District Head of Kagarko where there is no Sarkin Maka'da.

5. Head of masu kalangu of the Chief of the Strangers' Quarter (Tudun Wada) of Zaria. Though he is most often called Sarkin Maka'da, his full title is Sarkin Maka'dan Tudun Wada.

6. Head of all of the masu kalangu of Zaria, who was turbanned by the Chief of the Butchers (Sarkin Pawan Zazzau). His full title is Sarkin Maka'dan Sarkin Pawan Zazzau.

7. Number 5 and 6 above are occasionally addressed as Sarkin Kalangu.

See marok'an sarakuna, marok'an Sarki, Sarkin Kalangu.

Sarkin Maka'dan Gangar Noma

Sarauta title of several heads of masu gangar noma turbanned by District Heads within the Emirate of Zaria. One such head, Garba, the Sarkin Maka'dan Gangar Noma of Mak'arfi District, is a well-known singer. See Sarkin Maka'dan Gangar Noman Zazzau.

Sarkin Maka'dan Gangar Noman Zazzau

Head of all of the masu gangar noma of Zaria and turbanned by the Emir. However, he is not consid- 
ered one of the regular marok'an Sarki, though he performs for the Emir on such occasions as royal cavalcades (hawan daushe and hawan sa1la).

\section{$\underline{\text { Sarkin Maka'dan Kotso }}$}

Head of masu kotso of the Emir of Katsina. See Magajin Kotso, marok'an Sarki.

Sarkin Tambari

1. Head of tambari drummers of the Emir of Zaria, a non-professiona1.

2. Head of tambari drummers of the chief of the former vassal kingdom of Kajuru, now a district of Zaria. He is also a non-professional.

See tambari, Bikon Tambari, Tambura, marok'an Sarki.

$\underline{\text { Sarkin }} \underline{\text { Taushi }}=\underline{\text { Sarkin }} \underline{\text { Tabshi }}$

1. Head of the masu taushi of the Emirs of Katsina and Zaria. The principal assistant of the Sarkin Taushi of the Emir of Zaria holds the sarauta title of Madakin Taushi.

2. Head of masu taushi of the District Head of Kubau in Zaria. Lesser sarauta titles of his assistants are Madakin Taushi and Ciroman Taushi.

See marok'an Sarki, marok'an sarakuna.

\section{$\underline{\text { Tambura }}$}

Head of tambari drummers of the Emir of Katsina, a non-professional musician. 



\section{Patrons}

\section{Explanation of Numerical Indices}

Example: Farmers

manoma p1. (manomi m.s.)

1. (Description)

Farmers.

2. (Musicians traditionally patronized) masu gangar noma.

3. (Occasions)

gayya, kalankuwa.

4. (Role of patron and miscellaneous)

Either as an individual or as a member of a class they may act as a sponsor of take.

attajirai pl. (attajiri m.s.)

1. Wealthy merchants.

2. As individuals, attajirai patronize al1 sorts of marok'a and, along with sarakuna, they are the principal patrons of famous singers, who often compose special songs for them.

3. buki, tashen azumi, yawon salla. May be visited any time by touring musicians. 
karuwai p1. (karuwa f.s.)

1. Harlots.

2. All sorts of marok'a, especially masu kukuma and masu goge.

3. Any time and on special occasions, such as yawon sa11a and tashen azumi.

4. One or more men may act as sponsor of kirari for a favorite karuwa, and competition among sponsors may develop. Karuwai also may act as sponsors of kirari (for themselves).

Harlots sometimes play the kukuma or shantu for themselves and their patrons.

maharba p1. (maharbi m.s.)

='yan farauta p1. ('dan farauta m.s.)

1. Hunters .

2. masu komo.

3. buki, bago, na'din sarauta, hawan salla.

4. Either as an individual or as a member of a class they may act as a sponsor of take, termed taken maharba, and engage in self-praise (kirari).

mahauta pl. (mahauci m.s.)

='yan fawa pI. ('dan fawa m.s.)

$=$ rundawa $\mathrm{p} 1$. (barunje m.s.)

1. Butchers.

2.a. masu kalangu.

b. see also maka'dan 'yan tauri.

3. ki'dan fawa (= ki'dan nama), buki, hawan k'aho, na'din sarauta, tashen azumi. (Since 'yan dambe are most often butchers, dambe [boxing] may also be included here.)

4. Either as an individual or as a member of a class, they may act as a sponsor of take, called taken mahauta. 
mak'era pl. (mak'eri m.s.)

1. Blacksmiths.

2. 'yan dundufa.

3. buki, na'din sarauta, aure, suna $\frac{\text { sashen }}{\text { dry }}$ azumi the blacksmiths (Sarkin Mak'era) each Friday after the mosque (gaisuwar juma'a).

4. May act as sponsors of kirari and take, called taken mak'era.

malamai p1. (malami m.s.)

1. Islamic teachers and scholars specializing in either Koranic studies or other branches of learning.

2. masu ki'dan buta.

3. watan azumi, K'aramar Sa11a, Babbar Sa11a.

4. As member of a class they may act as sponsor of ki'dan malamai.

manoma pl. (manomi m.s.)

1. Farmers.

2. masu gangar noma.

3. gayya, kalankuwa, buki.

4. Either as an individual or as a member of a class, they may act as a sponsor of take and engage in self-praise (kirari).

marok'a $\mathrm{pl}$.

(marok'i m.s., marokiya f.s.)

1. Professional instrumentalists and vocalists. See marok'a, II-A.

2. karen marok'a.

3. aure, buki, suna, tashen azumi, yawon sa11a.

4. May act as sponsor of kirari. 
masu wasa da kura pl.

(mai wasa da kura m.s.)

$=$ gardawan kura p1.

(gardin kura m.s.)

1. Conjurer who wrestles with, and ostensibly tames, hyenas in the market place.

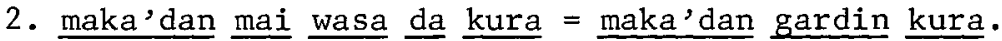

3. wasan kura in the market place (kasuwa).

Northern Peoples Congress (N.P.C.) and

Northern Elements Progressive Union (N.E.P.U.)

1. Major political parties in northern Nigeria prior to the first military coup of January 1966.

2. masu goge and masu kukuma with 'yan k'warya and na buta.

3. Al1 party functions, especially rawan kashewa, wasan N.P.C. or wasan N.E.P.U. and visits of important politicians for political rallies and the like.

Note: a11 kinds of marok'a performed at large political rallies, including a party poet, mawak'an N.P.C., and famous singer/instrumentalists like Ibrahim $\mathrm{Na}$ Habu, who bore the title, probably selfbestowed, of Sarkin Wak'ar N.P.C. ("The Chief Singer for the N.P.C.").

samari pl. (saurayi m.s.)

1. Young men.

2. masu kwairama, masu kalangu, masu gangar noma and masu tallabe.

3. rawan 'yan mata, buki, rawan misisi, kalankuwa, rawan Gane, a sha k'afa, kokawa, dambe, ajo and gayya.

4. As individuals, they often act as a sponsor of their own take (taken samari). 
sarakuna pl. (basarake m.s.)

$=$ saraki $\mathrm{pl}$. = sarakai $\mathrm{p} 1$.

$=$ masarauta $\mathrm{p} 1$.

1. Any officeholder whose installation is marked by the receipt of a title and a ceremonial turbanning at the hands of his patron or the deputy of the latter. Such patrons of marok'a are normally Emirs and high officials under them, resident in the capita1, and district heads, resident in district capitals. Village heads of Zaria and Katsina ordinarily do not have their own musicians, but village heads in certain villages of historical importance do (e.g., Kurfi, Gazobi, Lere, etc.).

2. marok'an sarakuna, marok'an Sarki, marok'an hakimai, marok'an fada.

3. waza (= sara), wazan salla, yawo, yawon salla, hawan salla, hawan daushe, hawan kilisa, buki, na'din sarauta, suna, aure. Annual inspection tours (rangadi) and official business trips of the Emir and District Heads.

4. Officeholders act as sponsors of special take (taken sarakuna) associated with their sarauta title. They also act as sponsors of kirari and of songs composed not only by their own musicians but also by famous freelance singers.

'yan bori $\mathrm{pl}$.

'dan bori m.s., 'yar bori f.s.)

1. Male and female initiates of the bori spirit possession cult.

2. masu garayan bori, masu goge, masu duman girke, 'yan k'warya, masu kasam 'bara, masu gora.

3. rawan bori, hawan bori and girka.

4. Initiates and spectators sponsor kirari for themselves and for spirits (iskoki).

'yan dambe $\mathrm{pl}$. ('dan dambe m.s.)

1. Boxers; most are local amateurs, but some are famous and travel widely, e.g., Shago, now retired, and his well-known singer, 'Dan Anace. 
2. masu kalangu.

3. dambe.

4. They act as sponsors of take or kirari performed at boxing events, or when the boxer is a spectator of the girls' dancing (rawan 'yan mata). They also praise themselves (kirari) when excited by praise of marok'a.

'yan hoto p1. ('dan hoto m.s.)

1. Strong men, conjurers and dancers who perform in farming costume and usually perform tricks with a hand-plough. Since they are primarily farmers they normally perform and tour (cin rani) after the harvest.

2. masu gangar noma with masu kazagi and with marok'an baki.

3. wasan 'yan hoto, kalankuwa, K'aramar Sa11a and any large public gathering.

4. They act as sponsors of take or kirari and praise themselves when excited by praise of marok'a.

'yan mata pl. ('yar mata f.s.)

1. Unmarried young women and girls.

2. maka'dan 'yan mata, masu kalangu, masu kwairama, and masu gangar noma (rare today).

3. rawan 'yan mata, wasan misisi, kalankuwa, kwanta $(=$ kwance $)$, kai gara and buki.

4. 'yan mata may dance and/or perform wak'ar 'yan mata. Some 'yan mata have their personal take sponsored by themselves, by older female kin or by a suitor.

'yan kokawa pl. ('dan kokawa m.s.)

$=$ 'yan kokuwa $\mathrm{p} 1$. ('dan kokuwa m.s.)

1. Wrestlers.

2. masu kwairama. 
3. kokawa.

4. They act as sponsors of take and kirari and praise themselves when stimulated with praise by marok'a.

'yan tauri p1. ('dan tauri m.s.)

$=$ k'ufegeru p1. ( $\mathrm{k}^{\prime} \mathrm{u}$ fegere $\mathrm{m} . \mathrm{s}$. )

1. Famous for their powerful medicine, which is said to make them invulnerable to attack by any sort of metallic or other hard object. They exhibit their powers in public competitions, wasan 'yan tauri, and act as bodyguards to important officials. Most of them are either butchers or hunters.

2. maka'dan 'yan tauri.

3. wasan 'yan tauri, buki, na'din sarauta, hawan salla, daba, ki'dan mahauta and dambe.

4. Either as individuals or as a member of a social group they may act as sponsor of take and kirari. They also praise themselves when excited with praise by marok'a. 



\title{
IV. Occasions
}

\section{Explanation of Numerical Indices}

\author{
Name(s) of occasion (alphabetized headings)
}

1. Description of social context of performance, venue, and, if necessary, amplification of performer's role beyond information given in Section II, Part B.

2. Time of performance.

3. Class of performers.

ajo (d.f. Yoruba)

jama'iyar neman arziki

1. A public meeting and entertainment organized by a bridegroom's friends to raise money to meet marriage expenses and held on the streets of larger towns in front of the entrance house of his residence, or in halls or hotels hired for the purpose. Friends of the bridegroom, encouraged by praise of him and his family by professional acclamators, singers and their bands, subscribe money, the amount being announced to the gathering with words of praise for the donor by an acclamator. It is understood that the bridegroom will attend future ajo of his friends and not only reciprocate but also give a subscription greater than the one he himself received.

2. He1d in the evening of the buki or up to several days afterwards.

3. Al1 sorts of marok'a, as above, especially popular singers and instrumentalists, who can draw a crowd. 
a sha k'afa ("to drink the feet")

1. A dance done by young men which is also a kind of foot-boxing. They whirl on one foot with the other foot outstretched causing the circle of spectators to expand (sharan fage). Sometimes they hit their opposites with considerable force as in the following kirari for a victor:

Ga mai tambari da sawu ga mai duka a fa'di "Here is the tambari drummer who beats with his foot and knocks his opponent to the ground."

2. Any evening, often after the girls finish dancing (rawan 'yan mata).

3. masu kalangu, 'yan kuntuku, masu kwairama and marok'an baki.

aure

Hausa marriage. Though the rituals of marriage are numerous, varied, and complex, some of the basic ones may be outlined here in more or less chronological order:

a. baiwa

1. Public betrothal, which is usually held in the morning in the residence of the girl's parents, and carried out by representatives of both the boy and the girl and witnessed by Koranic scholars and guests. Sometimes the date of the marriage (sa rana) is set at this time. Marok'a in attendance announce the betrothal and then call for prayers.

2. Often held more than a year before the actual marriage.

3. Different classes of marok'a may attend, especially those traditionally tied to the boy and his family.

b. sa rana

1. Literal1y to "set the date" of the marriage, a ritual which is usually held in the morning in the residence of the girl's parents. Marok'a 
announce the date, shout blessings and call for prayers.

2. Held either at the same time of the betrothal (baiwa) or between betrothal and marriage.

3. As for the baiwa.

c. 'daurin aure (= aure)

1. Literally "the tying of the marriage," the actual marriage ceremony, which is usually held in the morning in the residence of the bride's parents. Marok'a announce the amount of the sadaki (a marriage payment), the witnessing of the marriage and the commencement of prayers.

2. Usually after the harvest of cash crops; the day of the month is set by a Koranic scholar.

3. Same as for the baiwa.

d. tarewa

1. Bridal procession to the husband's house held later in the day of 'daurin aure. The girls accompanying the bride sometimes sing special songs.

2. As above.

3. Normally no professional musicians are present.

e. buki (= biki)

1. The marriage feast (bukin aure) held in the evening at the husband's residence (another buki is held by the bride's parents but it is not as important from the standpoint of the performance of music). Marok'a perform outside the entrance hut (zaure), where they drum for the dancing of the girls and/or provide music for an ajo. Sometimes a professional female singer (e.g., masu amada) performs in the inner residential quarter for the married women. The latter may perform their own songs, accompanying themselves with drumming on calabashes ( $k^{\prime}$ warya).

2. As above. 
3. Many classes of marok'a may attend, especially those traditionally tied to the bridegroom or his family.

f. kai gara

1. Procession of girls and women transporting the bride's dowry to her husband's residence. A drummer ( $s$ ) marches in front of the procession with one or more professional acclamators (marok'an baki), and the latter shout the contents of the dowry for the public to hear. The girls sing in leader and chorus response style. The drummer may stay for a while at the husband's house to accompany dancing of the girls (rawan 'yan mata).

2. Held in the morning, usually about one week after the 'daurin aure.

3. masu kalangu and masu k'wairama.

Babbar Sa11a

1. An annual festival ('Id el Kabir) which, like the companion festival of $\overline{\mathrm{K}}$ aramar Salla, is an occasion for the performance of music, ranging from music of the court to music for butchers; but ordinarily there is less musical activity than at K'aramar Salla. See tambari for customs related to the performance on royal drums in various emirates.

2. On the 10th day of Zu1 hajji.

3. Many classes of professional and non-professiona1 musicians.

bago

1. A bush-drive in which a large group of hunters (maharba) surround game or drive them with bushfires. The lutenists of the hunters (masu komo) perform their patron's take around the campfire the night previous and accompany them to the hunting place, playing en route.

2. Harvest time (kaka).

3. masu komo. 
$\underline{\text { bori }}$

1. A spirit possession cult whose male and female members ('yan bori) must undergo an initiation (girka). The initiates, mostly women, are possessed (hawa, lit. "mounted") while dancing by various spirits (iskoki) or gods of the bori pantheon, which is headed by the spirit called Sarkin Maka'da ("The Chief of the Drummers"), in contradistinction to the status hierarchy of real 1ife. Marok'a play an important part in bori rites, providing the drumming for dancing ( $\mathrm{ki}$ 'dan bori) and the praising of iskoki in song (wak'ar bori) and in speech. Many Hausa patronize these ceremonies to cure physical and psychological ailments and also simply for excitement and entertainment. Iskoki are also called to give blessings on the establishment of a market or for a wedding when married women may perform ki'dan ruwa to accompany the dancing.

2. Throughout the year; less during the farming season. Held for a few days during K'aramar Salla and Babbar Salla, and, of course, for girka.

3. masu garaya, masu gora, masu kasam'bara, masu goge, 'yan k'warya and marok'an baki.

$\underline{\text { buki }}=\underline{\text { biki }}$

1. Any celebratory feast, such as aure or suna, which often involves performance of celebratory music by both marok'a and non-professionals.

2. Aure (marriage) feasts occur usually after the cash crop harvests. Suna (naming) feasts, of course, occur anytime.

3. Different classes of marok'a may attend, especially those traditionally tied to the hosts. Wealthy persons often have popular singers and instrumentalists for these occasions.

\section{cin rani ("eating the dry season")}

1. Professional tours during the dry season after the agricultural work is done. All sorts of musicians make extensive tours at this time. They commonly make two annual tours: one just after the food-crop harvests and another after the cash-crop harvests, when the markets are especially active and money 
relatively plentiful. Marok'a also use the term yawo for travelling from one patron to another, and court musicians accompany their patrons on bush inspection tours called rangadi.

\section{daba (d.f. Durbar)}

1. A cavalcade, like hawan salla below, held in honour of a visiting dignitary.

2. Anytime.

3. Marok'an Sarki and other low-ranking clients of the Emir make up the procession.

da'be

1. Flattening and finishing an earthen floor, work by women to the accompaniment of song (wak'ar da'be).

2. Anytime.

3. Non-professionals.

dambe

1. Boxing by young butchers or hunters. Famous boxers like Shago (now retired) tour with their musicians, some of whom are famous in their own right, like 'Dan Anace, Shago's praise singer. Local boxers have resident marok'a play for them. Before the boxing begins, the drummers play the boxer's take, the acclamators shout their praises, and, sometimes, songs of praise are sung. Seemingly excited by all of this praise, the boxer begins to tremble (tsuma) and, with arms outstretched, shouts his own praises (kirari). The musicians also issue a challenge (kiranye) in behalf of the boxer. The drumming is stopped during the boxing and resumed after it is finished in honour of the victor.

2. After the harvest and, again, in the case of local boxers, during K'aramar Salla and Babbar Salla.

3. masu kalangu, marok'an baki and 'yan agalanda. 
gaisuwar juma'a

1. A visit by a marok'i or other client to a patron's home to greet him as a token of respect.

2. After the prayers held at the mosque on Friday.

3. Any marok'a, especially those tied to a distinct class of patrons.

gayya = gayyar noma

1. Cooperative farm work by rura1 youth, e.g., making ridges for planting cotton with large hand-ploughs (garma). Occasionally gayya are concerned with public works, such as clearing paths, and work of this kind may also be done in the city. Though the work is often hard, a festive atmosphere prevails. The host, who is often a Village Head or a District Head, provides refreshments and the girls come out to view the proceedings and to encourage the workers by singing praise songs, though the latter is less common today. Drummers beat the personal take of workers and often sing their words and acclamators shout kirari. A worker (particularly a 'dan hoto) will stop, quiver a moment, and with his arms outstretched, praise himself before working mightily again.

2. The farming season (damina, 1it. the "rainy season").

3. masu gangar noma, 'yan kazagi and marok'an baki.

hawan daushe

1. Similar to hawan salla below, but held two days later.

hawan kilisa

1. A cavalcade like hawan salla below, but on a smaller scale and done for "pleasure."

2. Anytime.

3. Marok'an Sarki with some other courtiers. 
hawan salla

1. Royal cavalcade from the palace of the Emir of Zaria to the praying ground outside the city walls and back again, and from the palace of the Emir of Katsina to the central mosque and back again, and made up of high-ranking officialdom and their clients.

2. Annual Muslim feasts of K'aramar Salla ('Id el Fitr) and Babbar Salla ('Id el Kabir).

3. Marok'an sarakuna -- many of whom are on horseback -- plus some other classes of musicians: masu komo, maka'dan 'yan tauri, masu goge, mawak'an Caji and zabiyoyi.

kalankuwa

1. A harvest-time festival of the rural youth which varies in scope and content. In Zaria, it seems to have been associated with actual co-operative farm work (gayya), but today all one normally encounters is mock farm labour by village youths in which tricks and feats of strength with hand ploughs are done in late afternoon in a field next to the village or in the village square itself. The performers are encouraged by the drumming of their take and the shouting of their kirari. Touring 'yan hoto, who perform the most elaborate feats of strength as well as sundry acts of magic (wasan 'yan hoto), are sometimes the only performers. This may be followed by wrestling (kokawa) or boxing (dambe) and in the evening a kwanta and wasan misisi, and gambling and goge music may be added to the evening's entertainment.

2. As above.

3. Masu gangar noma, 'yan kazagi, and marok'an baki for the farming play and 'yan hoto performance. See the other occasions for other classes of performers.

$\underline{\text { K'aramar }} \underline{\text { Salla }}$

1. An important feast ('Id el Fitr) which marks the close of the fast month. Some idea of the variety of music performed during this festival may be had from the following 1 ist of performance occasions recorded for this period in Zaria City in 1964: 
hawan salla, hawan daushe, wazan salla, yawon salla, wasan misisi, kwanta, rawan 'yan mata, wasan yan hoto, dambe, kokawa, and rawan kashewa. Prior to the festival there is $\mathrm{ki}$, dan fawa in the market and, sometimes, hawan k'aho. For customs related to beating of the royal drums, see tambari.

2. The first day of Shawal; however, many of the above performances take place on succeeding days.

3. Nearly all classes of performers, professional and non-professional.

\section{$\underline{\text { ki'dan }} \underline{\text { fawa }}=\underline{\mathrm{ki} \text { 'dan }} \underline{\text { nama }}$}

1. Drumming for butchers in the market to attract business or to announce slaughtering. The latter is more often done in smaller communities where slaughtering is not an everyday occurrence. When performing in the market, the drum rhythm (take) may be "saying":

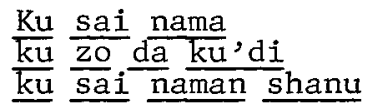

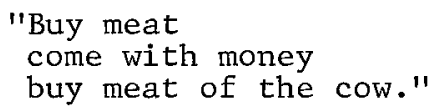

2. As above. Before important religious feasts (K'aramar Salla, Babbar Salla and Sallar Cika Ciki), they perform in the market and perhaps do ki' dan hawan $k^{\prime}$ aho for wasan hawan $k$ 'aho. In Zaria City, they most often drum in the market on Friday morning and sometimes on Wednesday and Sunday mornings.

3. masu kalangu.

$\underline{\text { kokawa }}=\underline{\text { kokuwa }}$

1. Wrestling by young men. There is drumming of their take, acclamation (kirari) by marok'an baki and, sometimes, singing of praise songs by the principal drummer (mai kwairama), with the chorus sung by the 'yan kazagi. This normally causes the wrestlers to quiver (tsuma) and to praise themselves before beginning to wrestle. 
2. Anytime during the dry season, especially for buki and kalankuwa or when the community head calls for it.

3. As above.

\section{kwanta (kwance)}

1. A formal expression of courtship or institutiona1ized love-making (tsarance) which is organized by the drummers of the youth at least once a year. In kwanta, which means "untied," the girls sit ("tied") on a mat in front of the drummers in the dancing place (filin rawa) until their boy friends -- or, less impressively, their kinsmen -- "untie" them by giving a gift in their name to the marok'a. A marok'in baki then shouts "he" to stop the drumming and announces, for example, "Abdu has given two shillings to untie Binta."

2. At K'aramar Salla or Babbar Salla or in connection with a harvest-time festival (kalankuwa).

3. masu kalangu, 'yan kuntuku and marok'an baki.

lugude $=\underline{\text { samammance }}$

1. Rhythmic pounding of any foodstuff by groups of women using one or more mortars (turmi) and each using a pestle. Extra percussive effects are produced by the pestle being struck against the side of the mortar on the up-stroke, followed by releasing the hands from the pestle, clapping them, and then catching the pestle for the down-stroke. Elaborated pounding of this kind, with hand-clapping, is considered "drumming," even without song. However, they often sing when doing lugude. Sometimes when a woman is grinding corn (nik a) while others are doing lugude, she will stop, pick up sticks and beat her grinding stone in concert with the others.

2. Done anytime, but usually when preparing food for a naming or marriage feast (buki).

3. Non-professionals. 


\section{$\underline{\text { Mauludu }}=\underline{\text { Maulidi }}$}

1. The Prophet's birthday and occasion for performance on tambura in Daura City.

\section{$\underline{\text { na'din sarauta }}$}

1. A ceremonial turbanning at the hands of a dispensing authority upon the occasion of the installation of a person in office and his receipt of a title.

2. No special time of year, but the fast month is avoided.

3. Marok'a, particularly marok'an sarakuna, are commonIy in attendance at such ceremonies.

\section{nik'a}

1. Corn-grinding by women on a stone block (resembling the Middle-American metate). Women often sing to the rhythm of the grinding. Any kind of song can be sung at this time and the words are often improvised. There are flattering or critical songs about a husband or a mother-in-law, and unflattering songs about co-wives (see wak'ar mata).

A proverb (karin magana) in which nik'a is referred to:

\section{Wak'a 'daya ba shi k'are nik'a \\ "One song is not enough to finish the grinding of corn."}

2. Year-around.

3. Non-professionals.

\section{rangadi}

See $\underline{\text { cin }}$ rani.

\section{$\underline{\text { rawan }}$ Gane $=\underline{\text { rawan }}$ takai}

1. A dance performed by young men and boys throughout Hausaland, accompanied by the beating together of sticks or short iron rods by pairs of dancers together with drumming. In Zaria, the dancers of 
rawan Gane wear short grass skirts and ankle rattles (cakansami) and sing songs abusing wrong-doers (wak'ar abayyana) in a manner that would not be tolerated at any other time.

2. At the end of the rains, or in Zaria during the month of Gane, the third month in the Muslim calendar.

3. masu gangar noma, masu kwairama and 'yan kazagi.

$\underline{\text { rawan }}$ kashewa $=\underline{\text { rawan } \text { banjo }}$

1. A dance by a group of young men and women hired for this purpose by a political party and said to have originated in the city of Jos. Most of the large cities in Hausaland had such dance teams, which travelled and competed with one another, performing often in outdoor courtyards of hotels. Admission was charged to view these competitions, which were called rawan kashewa or rawan banjo; however, the same dance was done in combination with other forms of entertainment at pre-election campaign meetings (wasan N.P.C. or N.E.P.U.). A dance team consisted of separate lines of female and male youths who danced a series of intricate steps in unison and each line of dancers was identically costumed in Western dress. Occasionally the male and female dancers paired off to dance the twist (tuwis) in the Western manner.

2. On weekends and, more often, preceding elections.

3. The most usua1 accompaniment for a performance was supplied by masu goge, and masu $k$ 'waryar goge or by masu kalangu playing with , dan kar'bi and 'yan kuntuku or by an ensemble of both groups of instrumentalists.

\section{rawan 'yan mata}

1. Dancing of girls to a number of dance rhythms (ki'dan 'yan mata) on Friday nights, on any night during a festival period (K'aramar Salla and Babbar Salla) and on any pleasant moonlight night. Young men normally act as spectators at the dancing place (filin rawa $=$ fagen rawa) and let their interest in a girl be known by paying the marok'a to call her out to dance. The girls also dance in connection 
with the following occasions: buki, kwanta, kalankuwa, wasan misisi and kai gara.

2. As above.

3. masu kalangu, 'yan kuntuku, maka'dan 'yan mata and masu kwairama.

\section{Sallar Cika Ciki $=\underline{\text { Sallar }}$ Wowwo}

1. The feast of the new year. Cika ciki means "full belly," the custom being to eat as much as one can at the feast. The drummers of the butchers (masu kalangu) are particularly busy playing for a parade of cattle to be slaughtered, which is usually associated with wasan hawan $k$ 'aho. Of course, they also perform for their patrons in the market place (ki'dan fawa).

2. Ninth and 10th of Muharram.

3. As above.

\section{$\underline{\text { Sallar }} \underline{\text { Takutufa }}=\underline{\text { Sallar }}$ Takutaha}

1. Prophet's naming day and occasion for performance on tambura in Daura City.

\section{suna}

1. A naming ceremony often held in the residence of the father's parents, in the case of a first-born child, or in the father's residence, in the case of subsequent children. Various kinds of music may be performed by marok'a but it is less often done in Zaria since the passage of the Beggar-Minstrel ordinance. Whether or not music is performed, marok'a are called upon to do the following: a) call the assembled for prayer; b) shout blessings for the mother and child to which the assembled respond "amin"; and c) announce the name of the child. In the evening a feast is held which normally involves the performance of music by both marok'a and others (e.g., women and girls).

2. Seven days after childbirth.

3. Marok'a of all kinds, especially those traditionally "tied" to the family, if any. 
$\underline{\text { tashen }} \underline{\text { Azumi }}=\underline{\text { tashe }}$

1. Singing, dancing, blowing and drumming in the streets and in front of homes during the month of Ramadan.

2. Most performances are after the evening meal up to around midnight; however, some stay up later to wake the citizenry so they may prepare food and eat before dawn.

3. Marok'a and non-professional youths, boys and gir1s, and old men who sing early in the morning.

$\underline{\text { wasan hawan }} \underline{\mathrm{k}^{\prime} \text { aho }}=\underline{\text { hawan }} \underline{\mathrm{k}^{\prime} \text { aho }}$

1. Entertainment involving acrobatics on and around a large, fierce bull. Prior to important feast days like Sallar Cika Ciki, bulls are paraded through the streets, and young butchers play with them (1it. "ride the horns") in front of generous patrons, homes to the accompaniment of a special kalangu rhythm (ki'dan hawan $\mathrm{k}^{\prime}$ aho) and the shouting of kirari by acclamators. Aside from the entertainment, the purpose of the play is to advertise slaughtering for the feast day. First, the bull is teased to arouse him and to frighten the spectators, and then the drumming becomes faster and the young man leaps over the horns and grabs the bul1 around the neck. When the play is over, the patron's gift is announced by a marok'in baki and shared between the young performer and the marok'a.

2. As above.

3. masu kalangu, marok'an baki.

\section{wasan kura}

1. The wrestling and ostensible taming of hyenas by professional entertainers who perform in markets to the accompaniment of drumming.

2. Any market day .

3. See maka'dan mai wasa da kura. 
wasan misisi

1. A "play of the miss or misses" presented by the youth associations of many wards in Zaria City and some rural communities, in which the girls dress in European clothes, nurses' uniforms and the like, and boys wear all sorts of uniforms of officialdom, of police, soldiers, doctors, etc. These "titled" persons rule the "commoners" with much horseplay of mock arrests, trials, fines and other "punishments." The girls serve tea and biscuits to their boyfriends, and the singers, drummers and acclamators praise all of the "titled" persons, the girls singing the chorus responses. The kwanta is then held, followed by dancing of the girls (rawan 'yan mata). Sometimes, after the food is consumed, a beauty contest is held and the winner is given the title of Sarauniyar kyau and wears a special sash.

2. In the dry season and during $\mathrm{K}$ 'aramar Sa11a.

3. mawak'an 'yan mata, masu kalangu, 'yan kuntuku.

wasan N.P.C. or N.E.P.U.

1. A wasa (1it. "play") of the leading political parties (prior to their abolition in January 1966) which was held to boost membership and/or to raise money by charging admission. Such occasions variously included performances by popular singers and instrumentalists, party poets, comedians, professional dancers (rawan kashewa) and bori drummers and dancers. Singers and acclamators praised party leaders, local officials and party supporters and censured their enemies. There was little speechmaking.

2. Anytime, particularly in the months just preceding an election.

3. As above.

wasan 'yan hoto

1. Entertainment by 'yan hoto, who are professional strong men, conjurers and dancers. They perform stripped to the waist, dressed in leather aprons and wearing many amulets including an animal horn with which, it is said, they shoot magic needles. They perform at kalankuwa, weddings (aure), market places 
and join in the work at co-operative-group farming gatherings (gayya). They also come to the city during feast days ( $\overline{\mathrm{K}}^{\prime}$ aramar Salla and Babbar Sa1la) and some tour widely.

In praise songs they are called masu nakiya da garma ("the throwers and catchers of hand ploughs"), a reference to one of their best-known acts. They a1so make deep cuts in the soil with hand ploughs and do other feats of strength, such as balancing a heavy $\log$ on their heads or carrying, pyramid fashion, two drummers plus their large farm drums on their shoulders. Among their most sensational conjuring acts is one in which a 'dan hoto imbeds a spear upright in the ground and sits and revolves upon the point. Acclamators (marok'an baki) cal1 their kirari and masu gangar noma drummers beat their take and sing praise songs with the 'yan kazagi drummers singing the chorus responses. Perhaps, inspired by all of this commendation, the 'dan hoto begins quivering and, with arms outstretched, praises himself.

2. As above.

3. As above.

wasan 'yan tauri

1. Public exhibitions and competitions of 'yan tauri, in which they display their invulnerability to aIl sorts of cutlery. It is generally believed that they accomplish this by drinking a secret herbal potion. To demonstrate the effectiveness of their medicine, they attempt to stab themselves with knives and swords, and some are said to even make a blade melt before it pierces the skin. They break razor blades with their fingers or attempt to cut their eyes with razors. They may perform in public places, in front of the homes of generous persons, or at the home of a fellow 'dan tauri upon the occasion of a buki.

2. Anytime, but especially during the dry season.

3. maka'dan 'yan tauri and sometimes masu kalangu. 
Watan Azumi

$=$ Watan Azumin Duk Gari

1. Ramadan, the month of fast. Professional, semiprofessional and non-professional musicians are active in connection with tashen azumi. Non-professional youths perform more during this month than at any other time of the year.

2. As above.

3. As above.

Watan Azumin Tsoffi

1. Month of Rajab (7th month), beginning and end of which are occasions for the beating of tambura in Daura City.

Watan Takutufa $=\underline{\text { Watan Takutaha }}$

1. Month of Rabi'i Lawwal, beginning of which is occasion for performance on tambura in Daura City.

Watan Wowwo

1. Month of Muharram, beginning of which is occasion for performance on tambura in Daura City as well as on day of Wowwo.

waza $=$ sara

$=\underline{\mathrm{k}^{i}}$ 'dan daren juma'a

1. A weekly, obligatory performance by musicians of officialdom outside their patrons' palace or residence.

2. Usual1y on Thursday evening (daren juma'a); however, certain classes of royal musicians of the Emir of Zaria perform on other nights of the week (e.g., masu jauje, masu banga and masu taushi).

3. marok'an Sarki and marok'an sarakuna. 
wazan salla $=\underline{\text { saran salla }}$

1. Like a weekly waza, but held on the eve of either K'aramar Salla or Babbar Sa1la.

yawon sa11a

1. Lit. the "salla strol1," in which court musicians (marok'an sarakuna) greet their patrons and other senior officials at their residence in expectation of receiving a gift (barka da salla or goron salla). During K'aramar Salla, head court musicians traditionally receive a gown and a turban. Other classes of musicians do yawon salla, too.

2. K'aramar Salla and Babbar Sa11a, especia11y the former.

3. Any kind of marok'a, but especially marok'an sarakuna. 


\section{Music \\ Performance}

For convenience of presentation terms have been grouped alphabetically within the following categories:

1. General performance features.

2. Vocal music, further subdivided into:

2.1. gangami: proclamation.

2.2. gu'da: ululation.

2.3. kiranye: challenges.

2.4. kirari: acclamation.

2.5. wak'a: song.

3. Instrumental music, further subdivided into:

3.1. bushe-bushe da ki'de-ki'de: blowing and drumming, playing a stringed instrument, and striking or shaking an idiophone.

3.2. miscellanea.

4. Dance. 
1. General Performance Features

amo m.s.

The highly resonant quality of the sound-signals of certain instruments, including ganga, kalangu, kotso, tambari, algaita, farai, and kakaki. The main criterion would appear to be the carrying quality of the sound-signals of such instruments. Thus it may be said, for instance, kalangu na amo ("kalangu is reverberating") or kalangu na tashi ("kalangu is rising").

amshi m.s. = amsa f.s.

A chorus response to a solo statement in either vocal or instrumental music, the response in almost all cases being in the nature of a refrain. Thus in song, a mawak'i ("solo singer") is answered by the masu amshi = "yan amshi = masu amsawa (the "chorus"), the latter group either merely supplying the refrain as a stanza marker (as in most songs by Alhaji

Shata), or else extending and completing the solo section before stating the refrain (as, for instance, in most songs by Sarkin Tabshin Katsina Alhaji Mamman). This is counterparted in instrumental music, e.g., kakaki, where a solo trumpet is sometimes answered by a chorus group of trumpets uniformly pitched at an interval approaching 100 cents higher than the solo instrument.

azanci $\mathrm{m} . \mathrm{s}$.

Creative inventiveness in any performance, vocal or instrumental. In vocal music the term is usually applied to a singer's use of language, the terms fasaha and hazik'anci being near-similes.

rok'o m.s. = garam m.s. = zuga f.s.

The professional acclamation of a patron in hope of reward, from which is derived the derogatory term for any professional musician -- marok'i m.s., marok'iya f.s. Such acclamation may take the form of either vocal (kirari, wak'ar yabo) or instrumental (take) music, and in the case of the former is usually compounded of extravagant praise of the patrons' 
identity, ancestry, characteristics and prospects. By a popular extension of meaning the term may be loosely, and inaccurately, applied to performance by any professional musician, whether such a performance is based on praise of a patron or not (cf. wak'ar nasha'di), and to presentation of himself before his patron in expectation of reward by a musician without actual performance. The latter is also termed raraka, whether done by a musician or non-musician. The socially acceptable acclamation of God or a human patron by a cripple or Koranic student is termed bara.

salo m.s.

The stylistic identity of a composition, compounded from such features as text (if present), melody, rhythm, and timbre.

shiri m.s.

The preparation of a composition for performance, whether vocal or instrumental, including the utterance of a dedicatory prayer (addu'a). In vocal music shiri may take the form of gunguni; in instrumental music, jinjina.

2. Vocal Music

2.1. gangami m.s.

An official proclamation ordered by an authority such as an Emir or a District Head, and announced by word of mouth with drum accompaniment, usually on gangar fada. Proclamation by word of mouth alone is known as yekuwa, and is not included herein since it does not depend on performance by a musician.

a. karin magana:

Tun da ka ji gangami ka tabbata akwai magana a baya

"Because you have heard the proclamation drummed, 
you may be certain there are words behind it," i.e., "There's no smoke without fire."

2.2. gu'da m.s.

Celebratory ululating by women, any woman specializing in this being termed magu'diya.

a. kirarin ango ("kirari for a bridegroom")

Arushi sha gu'da

"Bridegroom, experience -- ululation."

b. Ango ba gu'da

"Bridegroom, causes -- ululation."

c. kirarin kuyanga ("kirari for a female slave")

Tumun yaki manzon gu'da

"The first harvest of war and heralder of ululation (celebrating a victory)."

2.3. kiranye m.s.

A challenge issued on behalf of a 'dan dambe ("a boxer") by a musician, usually with drum accompaniment, e.g., on kalangu, such challenge being in the form of an extended kirari stating the prowess of the sponsor/patron.

2.4. kirari m.s.

A vocal text in praise and identification of a patron (similar texts in identification of inanimate objects and animals do not normally form part of music performance). Acclamatory performance of such a text may occur in isolation or at the same time as a song or instrumental performance in honour of the same patron. A performer specializing in the performance of kirari alone is usually known as either 'dan ma'abba, babamba'de, marok'in baki, mai kirari, or San K'ira, while the total performance, including the performer's motives and behaviour, is termed ma'abbanci m.s. or bamba'danci m.s. 
2.5. wak'a f.s. (p1. wak'ok'i)

Any song composed by a professional or non-professional musician, or a written poem composed by a non-professional poet. A song or poem composed on a topic in which the singer or poet specializes may be termed wak'e m.s., the main topics of such specialization being religion and religious teaching, history and socially censorable behaviour. Both the professional singer/composer and the non-professional poet may be termed mawak'i, though the latter may be further defined as mai rubuta wak'a m. or f.s. = mai rubutu wak'a m. or f.s. ("the writer of a song"), or mai wallafa ("the author of a written work"); the composition of a song may be termed yin wak'a m.s. and of a poem, shirin wak'a m.s., rubuta wak'a m.s. = rubutu wak' wallafa wak'a m.s.; the performance of both a song and a poem may be termed yin wak'a m.s. or rera wak'a m.s. In addition to the above, various terms referring to features common to more than one type of song and/or poem are 1isted under 2.51 , below. Further terms referring to particular song types or categories, are for convenience listed alphabetically under the following sections:

2.52. wak'ar addini ("religious song")

2.53. wak'ar bori ("possession song")

2.54. wak'ar nasha'di ("entertainment song"), or a broad category including such extremes as tarihi ("historical narrative") and zambo ("songs of ridicule")

2.55. wak'ar siyasa ("politica1 song")

2.56. wak'ar yabo ("praise song")

The above categories are never watertight when examined from the point of view of their texts, the major criterion in assigning a song to one of these categories being the singer/composer's intentions.

2.51. Miscellaneous terms common to various song-and-poem types.

bege m.s. 
A nostalgic longing expressed in song or poem for an absent or dead person. Such longing may be expressed in a religious song or poem (e.g., a yearning for the Prophet), a love song, or a political song (e.g., a yearning for a departed leader).

Caji m.s.

A song style thought to have been originated by Hamza Caji, and currently practiced by such singers as Hamisu Caji, Ibrahim 'Dan Mani Bauci and Dogara Caji.

'dango m.s.

A hemistich in a written poem (cf. she'dara).

fasaha f.s.

Any skill, but here applied to "literary" skill in the composition of a song or poem. The more specific term is hazik'ancí (below).

gajarta m. or f.s.

The shortness of a song or poem, or of a line thereof, and as such a specific value of ma'auni.

gunguni m.s.

Humming, employed by a singer or poet in testing the suitability of a metre and/or melody for the composition of a song, or employed as a preliminary to actual performance.

hazik'anci m.s.

"Literary" skill in the composition of a song or poem (see fasaha, above), such skill being displayed in the choice of words and statements to convey an idea, and in the suitability of this choice to the metre and melody chosen for the song or poem. 
1ele m.s.

A positive longing expressed in a song or poem (cf. bege, above); also the type of singing used for tawai (rocking an infant to sleep, dandling it on the knee, etc.).

ma'auni m.s.

The general length value of a song or poem, or of a line thereof, the more specific values being gajarta and tsawo.

murya f.s.

A single syllable of a song or poem, the linguistic tone or quantity thereof, or the musical pitch or length value of such a syllable in performance.

Shata m.s.

A style of singing originated by Alhaji Muhamman Shata, the most popular of al1 present-day Hausa singers, and imitated by numerous lesser singers.

she'dara f.s. (p1. she'daru)

A written line of a poem, usually consisting of two 'dango.

tsawo m.s.

The longness of a song or poem, or of a line thereof, and as such a specific value of ma'auni.

wak'ar mada'ba f.s.

Literally "a song accompanying floor-pounding," and used as a term for songs or poems without any structural values (e.g., no consistency of metre, no tonal rhyming, no quantitative rhyming, etc.). 
2.52. wak'ar addini f.s. (p1. wak'ok'in addini)

A religious song or poem, but most usually the latter, of which there are numerous sub-categories not listed here. A religious song as such is usually non-professional, though there are exceptions, and may be performed by almost anyone. A particular variety exists in the many religious texts sung for bara ("begging for alms") by cripples and blind people (musaka) and Koranic students (almajirai) with various sub-categories such as wak ar Takutaha, = wak'ar Tukutufa (a song or songs sung by blind women and girls from house to house on the Prophet's naming day).

2.53. wak'ar bori f.s. (pl. wak'ok'in bori)

A song in honour or praise of an iska ("a spirit or god"), and normally performed by musicians specializing therein either as part of an entertainment/spectacle, or to invoke the possession of a 'dan bori or 'yar bori (male or female possessiondancer) by the iska invoked. Each iska being traditionally honoured in this way with various songs, it follows that there are various sub-categories each related to the identity of one or the other of the numerous spirits invoked, e.g., wak'ar Sarkin Maka'da, wak'ar Barahaza, wak'ar Sarkin Rafi, wak'ar Kure, etc.

2.54. wak'ar nasha'di f.s. (p1. wak'ok'in nasha'di) = wak'ar nisha'di f.s.

An entertainment song, though this, as might be expected, belongs to an extremely large category. It is probably best divided into professional and non-professional song, though even here there is considerable overlap in subject matter.

2.541. Terms common to professional and non-professional wak'ok'in nasha'di.

gamtsi m.s. = alfahasha f.s. = batsa f.s.

Offensive sexual comment which, when it dominates 
a song text, may permit the latter to be termed wak'ar gamtsi, though this may be a somewhat contrived term. of frequent occurrence in many professional entertainment songs (e.g., gambara), it is also found in non-professional songs by women (e.g., work songs) as well as in songs by young girls and unmarried women (wak'ar 'yan mata).

zambo m.s. = yanke m.s.

Satire or ridicule of an individual or group of people, or censure of his or their conduct, which, when it dominates a song text, may permit the whole performance to be termed zambo.

2.542. Terms referring to professional wak'ok'in nasha'di. of the enormous body of songs that fall under this category, only a smal1 proportion permit terminological grouping, as below. Thus, much of the repertoire of such famous composers and singers as Alhaji Shata, 'Dan Maraya Mai Kuntigi, Alhaji 'Dan Alalo and others defies any more specific classification than as wak'ok'in nasha'di.

tarihi m.s.

Historical narrative, not in itself of frequent occurrence, but greatly esteemed by certain sections of the community and the specialty of individual singers (e.g., Sarkin Kotso 'Dan Maraya of Daura, whose tarihin Daura, or "history of Daura," is fairly widely known even outside the confines of that Emirate).

gambara f.s.

An extended vocal performance, usually by two or more 'yan gambara (m.s. 'dan gambara), in which the conduct of individuals and particularly their sexual behaviour is censored and made the subject of abuse and ridicule. In the performances of such a master of the art as Saleh Mai Gambara, the text is for the most part delivered in a recitation metrically regulated by the accompanying drumming, song (in the Western sense of stable pitch and length values) being reserved for 
points of structural and dramatic importance to the performance as a whole.

wak'ar bojo f.s.

An older and now rare form of bawdy song accompanied on kukuma and k'warya.

wak'ar caca f.s.

A song about gambling which, with wak'ar shan giya below, belongs to a possibly extensive group of songs deriding human frailties.

wak'ar gwauro f.s. = wak'ar gidan gwauro f.s.

A song ridiculing the life of a bachelor or spinster, and customarily sung with or without instrumental accompaniment during Ramadan. It is, however, of more frequent occurrence as a nonprofessional song type.

wak'ar shan giya f.s.

A drinking song which, like wak'ar caca above, derides human frailty or turns up a nose at accepted codes of behaviour. Outstanding examples of both of the above apparently opposed attitudes to drinking are found, for instance, in the two songs "Sha Ruwanka Ka Hole" and "A Sha Ruwa," both by Alhaji Muhamman Shata.

\section{'yankamanci m.s.}

A mildly satirical type of performance by one or more 'yan kama (m.s. 'dan kama) compounded of song, recitation, acting and clowning; the vocal parts of the performance are frequently parodies of famous songs by composers and singers such as Naramba'da, Jan Ki'di and Sarkin Tabshin Katsina Alhaji Mamman, the major distinction between 'yankamanci and gambara being in the completely proper nature of everything said and done in the former. 
2.543. Terms referring to non-professional wak'ok'in nasha'di. These are presented under categories defined by the age-group and sex of the performers.

2.5431. wak'ar yara f.s.

A children's song.

wak'ar tatsuniya f.s.

A song occurring as part of a tatsuniya, or "traditional children's story," such tatsuniya being normally told in the evenings and based on the adventures of both humans as well as animals and insects (e.g., Zaki, "Lion"; Giwa, "Elephant"; Gizo, "Spider," etc.). While such songs are normally unaccompanied by the children listening to the story, or by the narrator, more elaborate performances occur in which drums

(e.g., kalangu) are used to supply an accompaniment to the whole.

2.5432. wak'ar samari f.s.

Young men's song.

wak'ar abayyana f.s.

A song in ridicule of social misconduct, and performed in connection with rawan Gane, with drum accompaniment on gangar noma, kwairama and kazagi. An example of such a song:

Mai satan $\frac{\text { rogo }}{\text { TThe }} \frac{\text { rani }}{\text { cassava thief! }} \frac{\text { yi }}{\text { It }}$ is $\frac{\text { dube }}{\text { harveshi }}$ time, so let's look out for him!"

wak'ar macukule f.s.

A game-song performed in the streets during the evenings of the month of Ramadan. 
wak'ar rawan Gane f.s. = wak'ar rawan takai f.s.

A song associated with the dance known as rawan takai.

wak'ar tashi wali f.s.

A game-song performed in the streets during the evenings of the month of Ramadan.

wak'ar 'yan dako f.s. = wak'ar 'yan kura f.s.

A song sung by market porters pushing heavily laden trollies in and around urban markets, the singing helping to coordinate their efforts.

\subsection{3. wak'ar 'yan mata f.s.}

A girls' and young unmarried women's song. For occasions see buki, aure, rawan 'yan mata, wasan misisi, kai gara, tashen azumi.

ga'da f.s.

A more or less spontaneous breaking into song, dancing and handclapping. The girls sing and clap while playing the ga'da game, in which they form a circle and each în turn falls backward into the arms of her partners.

wak'ar arauye nanaye f.s. $=$ wak'ar nanaye f.s. = wak'ar asauwara f.s.

A song with no fixed topic, but characterized by the amshi ("refrain"), which employs the apparently meaningless formula arauye nanaye, or variants thereof (e.g., aye iye ayeraye, etc.). The attempt to relate these apparently nonsensical syllables to the names of the daughters of Satan is questionable as an historical and linguistic exercise, but acceptable as an expression of the disapproval of this type of singing held by many malamai ("religious scholars and teachers"). Though such songs are performed on a variety of occasions, the accompaniment is most frequently supplied on such drums as 
kalangu (with 'dan kar'bi and kuntuku , duma or dundufa. Exceptionally such songs may be performed by wanzamai (barbers). They are most often performed on the occasion of rawan 'yan mata and corn grinding (nik'a, see wak'ar mata, below).

wak'ar gwatso f.s.

A bawdy song sung to the accompaniment of such drums as kwairama with kazagi or kalangu with 'dan kar'bi and kuntuku.

2.5434. wak'ar mata f.s.

A women's song. The occasions on which women sing are varied, comprising work situations such as daka ("pounding," with the more specialized lugude and samammance), nik'a ("grinding," with the more specialized marka'de) and da'be ("flattening and finishing an earthen floor"), as well as such festive occasions as aure ("marriage"), suna ("naming-ceremony"), and the major Feast Days of Babbar Salla and K'aramar Salla. Accompaniment to such singing may be supplied by ta'bi (handclapping), or a shantu or ki'dan ruwa. While there would appear to be no fixed set of topics for such songs, those listed below as song types are some of the more common.

wak'ar kishiya f.s.

A song about a co-wife, and frequently a vehicle for zambo.

wak'ar miji f.s.

A song about a husband, either flattering or critical (zambo).

wak'ar uwar miji f.s.

A song about a mother-in-law, either flattering or critical (zambo). 


\section{4 / GLOSSARY OF HAUSA MUSIC}

\subsection{5. wak'ar siyasa f.s.}

Strictly speaking, a song propagandizing for a political party, sung prior to the collapse of the political system after the first military coup of January, 1966. As such, they were of most frequent occurrence in periods preceding an election, whether Regional or Federal, with certain musicians, especially masu goge and masu kukuma, aligning themselves with one or the other of the two major political parties in the Northern Region, as it then was. The most celebrated of such musicians were: Audu Yaron Goge, at first a supporter of N.E.P.U. (The Northern Elements Progressive Union) before finally changing his support to the N.P.C. (Northern Peoples Congress); Garba Liyo, Iike Audu Yaron Goge a performer on goge but always a staunch supporter of the N.P.C.; Ibrahim $\mathrm{Na}$ Habu, famous as a singer with kukuma accompaniment and supporter of the N.P.C.; Ali'Dan Saraki, a singer and performer on kukuma and supporter of N.P.C.; and 'Dan Maraya Mai Kuntigi, famous for his songs with kuntigi accompaniment, and for some time a supporter of N.E.P.U. By an extension of meaning the term wak'ar siyasa may now be taken to include any song in praise of a governmental authority other than those of the traditional Emirate.

wak'ar Gwamnati f.s.

A song in praise of the present military government of Nigeria and its leaders, headed by MajorGenera1 Yakubu Gawon.

wak'ar N.E.P.U. f.s.

A song in praise of N.E.P.U. and its leaders, and in condemnation of its political rivals.

wak'ar N.P.C. f.s.

A song in praise of the N.P.C. and its leaders, headed by the late Sardauna of Sokoto, and in condemnation of its political rivals. 
wak'ar soja f.s.

A song in praise of the Nigerian Army and its various commanders, and in condemnation of the secessionist leaders of Biafra under their leader, Colonel Ojukwu.

\subsection{6. wak'ar yabo f.s.}

A praise-song, the subjects of such songs varying from traditional rulers (Emirs and their officials) to important commoners (e.g., wealthy merchants, owners of transport companies), though even an unimportant commoner may be occasionally made the subject of a praise-song. Praise-singers themselves may be classed as either "tied" or "freelance," depending on their degree of dependence on a single patron or their freedom to act as independent agents in establishing a series of patronages. Most "tied" singers are attached to the courts of Emirs or of their officials, though a second but increasingly less common group exists among those musicians who, through their use of a particular accompaniment instrument, are traditionally, though not necessarily, tied to certain occupational classes (e.g., masu kalangu to butchers, masu komo to hunters, masu dundufa to blacksmiths, etc.). By the nature of their status, official "tied" musicians are obliged to specialize in wak'ok'in yabo to the exclusion of almost all other types of song, and this may partially explain the outstanding quality of the compositions of such singers, now almost legendary, as Dodo Mai Tabshi, Naramba'da, and Jan Ki'di, as well as those of such equally talented singers as the late Sa'idu Faro, 'Dan K'wairo and his elder brother Kurna, and Aliyu 'Dan Dawo. Freelance musicians are, however, at liberty to compose not only praise-songs, but also entertainment and political songs, though in spite of this diversity of subject matter a song such as Alhaji Shata's "Dodo $\mathrm{Na}$ Sardauna, "in praise of the Emir of Zaria, is certainly comparable with the best of the products of "tied" musicians. 
3. Instrumental Music

3.1. bushe-bushe da ki'de-ki'de $\mathrm{p}^{1}$.

Lit. "Blowings and drummings," the term in effect covers all instrumental music with the exception of performance on tambari, i.e., all blowing of wind instruments, beating of drums, blowing or plucking of stringed instruments, and rubbing, striking or shaking of idiophones.

busa f.s. (p1. bushe-bushe)

Blowing of any wind instrument (see Aerophones).

jinjina m. or f.s.

An introductory performance on a drum, wind instrument or stringed instrument, which serves both as a "warming-up" and as a dedicatory session. A jinjina is almost always based on the instrumental realization of the language tones and quantities of a non-verbalized text dedicating the performance to God, in which case it is termed rok'wan Allah $=$ rok'on Allah, or to an important patron by naming the latter and his qualities. An outstanding example of rok'wan Allah is that text used by the head of the kakakai (kakaki) players in Katsina every morning before leaving home:

Allah ne Sarki Mai Sama ne Sarki

Allah ne da gaskiya Mai Sama ne da gaskiya Sarkin sarauta Allah A1lah maganin k'ak'a nika yi Ūban $\bar{G} i \dot{j i}$ Shi ba da basira dangana Allah ta fi komi
"God is the King, The Lord of the Heavens is the King, God is Always right, The Lord of the Heavens is Always right,

The King of kings, God. God, the answer to Uncertainty, The Lord God Is the giver of wisdom, Trust in God Is the answer to all else." 
juya ki'da f.s.

A change of style in a performance on a drum, stringed instrument, or idiophone. The more specific types of change are: juyen take, a change of take; sake bugu, a change of style on tambari; sake hannu, a change of technique on a drum; salo-salo, the different styles of drumming on tambari.

take m.s.

The instrumental realization of the language tones and quantities of a normally non-verbalized text in identificatory praise of a patron as an individual, as a member of a class, or as an officeholder. Such texts are usually short and frequently epithetical in content, e.g., a take for any 'dan tauri.

'Dan tauri sha dadala

"Dan tauri, experience-cutting."

Terms for particular kinds of take may be formed by statement of the sponsor's name or class after the word take with a genitival suffix, thus, taken maharba, taken 'yan tauri, etc. Sponsors of take, either as individuals or as members of a class, are: bamba'dawa, maharba, mahauta, mak'era, malamai, manoma, marok'an baki, samari, sarakuna, sharifai, wanzamai, 'yan mata, 'yan dambe, 'yan hoto, 'yan k'odago,' 'yan kokuwa and 'yan tauri.

$\underline{\text { ki'da m.s. (pl. } \mathrm{ki}^{\prime} \mathrm{de}-\mathrm{ki} \mathbf{\prime}^{\prime} \mathrm{de}}=\mathrm{ka}$ 'de-ka'de)

$=\underline{\mathrm{k}^{2} \mathrm{di}} \mathrm{m} . \mathrm{s}$.

Beating a drum, bowing or plucking a lute, shaking, striking, plucking or rubbing an idiophone.

ki'dan amada m.s.

Drumming on a calabash (k'warya) -- usually a whole set of them ( $\mathrm{ki}$ 'dan ruwa) -- in accompaniment of a style of singing called wak'ar amada performed at buki for entertainment of women, usually by professional female singers called masu amada. A particularly popular subject is the ridicule of co-wives. However, the name for this style of singing seems to have sprung from a religious song sung by men, Koranic students or married women, in which each 
verse is terminated with the name "Amada," a reference to the Prophet Mohammed.

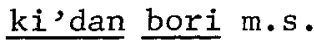

An instrumental performance for bori, i.e., in honour of an iska and to invoke possession by that iska. Terms for particular bori performances may be formed by statement of the iska's name after the word $\mathrm{ki}$ 'da with a genitival suffix, thus $\mathrm{ki}$ 'dan Sarkin Makada, ki'dan Sarkin Rafi, ki'dan Barahaza, etc. The most usual instruments for such performances are k'warya, garaya, goge or kukuma.

ki'dan bumbum m.s.

Druming for war on kurya.

ki'dan fada m.s.

Druming for an Emir on gangar fada.

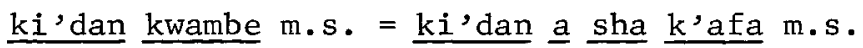

Drumming on kwairama or kalangu in accompaniment of a kind of whirling dance, which is at the same time a foot-boxing contest, and of songs in praise of youths.

$\underline{\mathrm{ki} \text { 'dan }}$ magori m.s.

Drumming to attract custom by the assistant of an herbalist.

ki'dan maharba m.s.

A performance on komo or babbar garaya, in honour of one or more hunters.

ki'dan mahauta m.s.

Drumming on kalangu in honour of one or more butchers, special classes of such druming being $\mathrm{ki}$ 'dan fawa, to announce slaughtering and attract custom, 
and ki'dan hawan $k$ 'aho, as an accompaniment to wasan hawan k'aho.

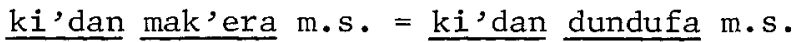

Drumming on the set of drums known as dundufa in honour of one or more blacksmiths.

ki'dan malamai m.s.

A performance on tandu, buta, and sometimes on such other instruments as zunguru, molo, or garaya, in honour of one or more religious scholars.

ki'dan manoma m.s. = ki'dan noma m.s.

Drumming on such drums as gangar noma, kwairama, or kuru in honour of one or more farmers, a specific class of such drumming being $\mathrm{ki}$ 'dan gayya for gayya, in which the take of individual farmers are drummed.

ki'dan rawan Gane m.s. = ki'dan rawan takai m.s.

Drumming on kwairama and/or gangar noma, in combination with kazagi for the annual dances (rawan Gane) and songs (see wak'ar abayyana, above) of the young men during the month of Gane.

ki'dan ruwa m.s. ("drumming on water")

Drumming by women on a set of calabash drums (k'waryar $k i$ 'dan ruwa) in the accompaniment of song, e.g. , wak'ar amada and bori dancing. The name derives from one of the calabash drums in the set which is inverted and floated on water in a larger calabash or bucket, and beaten with a stick.

\section{ki'dan wanzamai m.s.}

Drumming on kalangu in honour of one or more barbers, or in accompaniment of wak'ar arauye nanaye, or druming on ganga to attract customers and to accompany special songs designed to lessen a girl's fear of tattooing ( $k i$ 'dan jarfa). 
ki'dan wasa da kura m.s.

Drumming on tallabe or gangar noma, with kazagi for professional conjurers of hyenas. See wasan kura, maka'dan mai wasa da kura.

ki'dan 'yan mata m.s.

Performance on such drums as kalangu, dundufa, duma, kwairama, or gangar noma in the accompaniment of young girls, singing and/or dancing, though the latter may be more specifically termed ki'dan rawan 'yan mata, some of the more popular dance rhythms in Zaria in 1964 being: asauwara, na gyartai, 'dan k'odago, gidigo, mairo dike, lalayyo, lafsuru, soso, gwaja, shatan gimi and gwatso.

ki'dan 'yan dambe m.s.

Drumming on kalangu by masu kalangu for boxers at boxing matches (dambe), in which their take are drummed and songs of praise are sung (wak'ar yabo).

ki'dan 'yan hoto m.s. = wasan 'yan hoto m.s. $=$ kallankuwa $\mathrm{f.s}$.

Drumming on gangar noma and kazagi for performance of 'yan hoto.

ki'dan 'yan kama m.s.

Drumming by 'yan kama on gangar 'yan kama in accompaniment of their humorous speeches, songs and imitations.

ki'dan 'yan kokuwa m.s. = ki'dan kokawa m.s.

Drumming of take on kwairama by masu kwairama for wrestlers ('yan kokuwa) in accompaniment of their self-acclamation (kirari) and the wrestling itself.

ki'dan 'yan tauri m.s. = ki'dan kufegere m.s.

Drumming on talle by maka'dan 'yan tauri for the public appearance of 'yan tauri. The drumers play the take of the competitors, particularly at wasan 
'yan tauri, which often leads to self-acclamation (kirari).

3.2. Miscellanea.

bugu m.s. (pl. buge-buge)

Drumming on tambari, whether such action consists of an ensemble performance by Tambura and his assistants, or of individual strokes for the installation of certain high-ranking officials and the Emir. This term is also used occasionally for the beating of other membranophones.

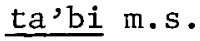

Handclapping, whether by women or men, though the latter is rare and used only for special effects (e.g., to indicate pleading as in Alhaji Shata's "Sha Ruwanka Ka Hole").

kin-kin-kin. . .

Human imitation of sound made by drum.

gan-gan-gan. -

Human imitation of sound made by drum.

4. rawa f.s. (p1. raye-raye)

A dance as such, dancing being yin rawa. For specific dances, see: rawan kashewa, a sha k'afa and rawan Gane in Section IV, and ga'da and $\overline{k i ' d a n ~ ' y a n ~ m a t a ~ i n ~}$ this section. 



\section{Hausa Index}

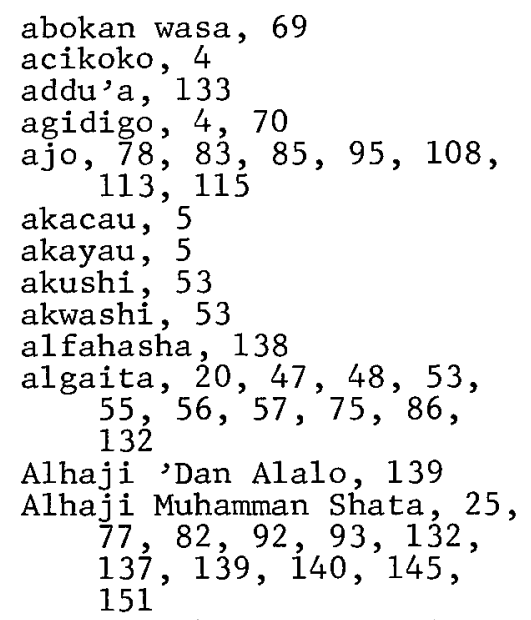

Alhaji Muhamman, Sarkin Tabshin Katsina, 132, 140

Ali 'Dan Maraya, 45

Ali 'Dan Saraki, 45, 82, 144

Aliyi 'Dan Dawo, 145

almajirai, 138

amada, 91

amale, 53, 55

amo, 132

amsa, 132

amshi, $71,132,142$

a sha k'afa, $21,78,80$, $108,114,151$

asauwara, 150

attajirai, 85, 91, 93, 105

Audu Karen Gusau, 70

Audu Yaron Goge, 42, 144

aure, $16,64,72,95,107$, $109,114,117,127$, 142,143

awara, 53

azanci, 132

babamba'de, 134 (see also bamba'dawa) babbar garaya, 40, 41, 82 , 84,148

Babbar'Salla, $10,16,18$, $35,36,37,64,71,80$, $107,116,117,118$, $120,121,122,124$, $128,130,143$

badujala, 12

bago, 84, 106, 116

baiwa, 114,115

bamba'danci, 94, 134

bamba'dawa, 76, 89, 94, 95, 99

bamba'de, 94

bambaro, 4

bandiri, 13

banga, 13, 53, 54, 56, 57, $58,65,74$

bara, 133, 138

barancaki, 5

barankaci, 5

barka da salla, 130

batsa, 138

bege, $85,91,135$

begila, 48

beli, 53

belu, 53

biki: see buki

Bikon Tambari, 98

bori, $7,41,70,82,95$, $109,116,127,148,149$

bugu, 151

buki, $64,70,71,72,74$, $76,77,80,81,83,84$, $85,86,91,92,94,95$, $105,106,107,108$, $109,110,111,113$, $115,117,122,125$, $128,142,147$

bukin aure, 115

bulala, 53

busa, 146

bushe-bushe da ki'de-ki'de, 131,146

buta, 5, 6, 54, 70,96

bututu, 48

buzu, 70 


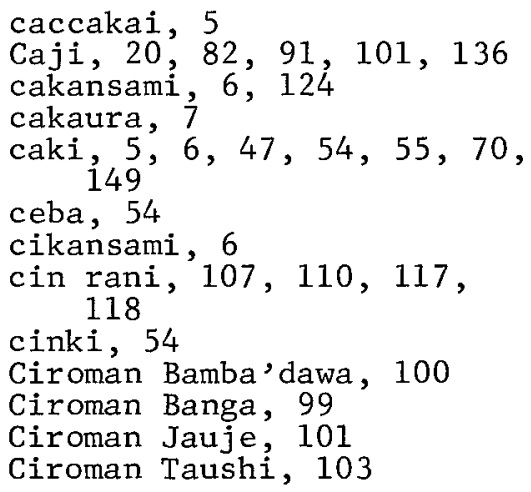

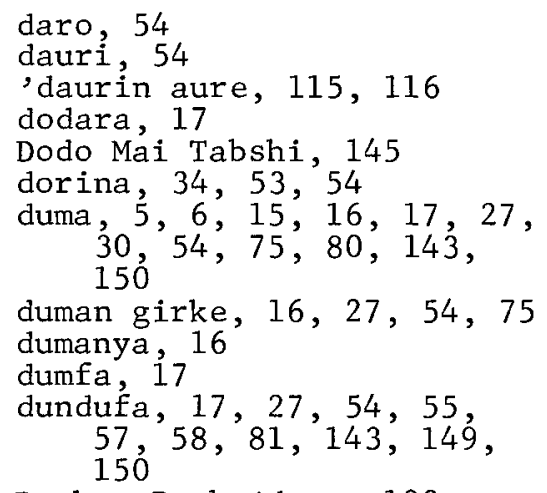

Dunkan Bamba'dawa, 100

Durbi, 36

Fagaci, 88

falami, 54

fallami, 54

famfami, 49

farai, $20,48,49,50,51$, $54,55,57,58,65,87$,

farke, 54

farko, 54

fasaha, 132, 136

fata, 54

filin rawa, 122,124

furya, 55

ga'da, 142, 151

gaisuwar juma'a, 64, 81, 107,119

gajarta, 136

Galadima, 8, 36, 37, 71, 98

Galadiman Banga, 99

Galadiman Rok'o, 99

Galadiman Zazzau, 89, 101

galura , 5, 6, 55, 96

Gamaruga, 32

gambara, $30,96,139,140$

gamtsi, 72, 96, 138

gan-gan-gan, 151

Gane, 124, 149

ganga, $9,18,21,30,54$, $55,56,57,58,92$,

gangami, 131, 133 
Gangan Wa'azu, 37

gangar algaita, 18, 20, 27, $48,75,81$

gangar Caji, 19, 20, 82, 92 gangar fada, $8,19,20,48$, $49,50,51,58,65,71$, 76,148

gangar noma, 6, 19, 20, 21, $27,30,54,71,73,76$, 149,150

gangar 'yan kama, 22, 54, $56,57,93,150$

garam, 132

garaya, 6, 7, 40, 41, 45, $46,53,54,56,57,58$, $82,148,149$

Garba Liyo, 42, 144

gardawan kura: see masu wasa da kura

gardin kura: see masu wasa da kura

garkuwa, 55

garma, 119

garura $, 5,6,54$

gayya, $76,95,96,107$, $108,119,120,128,149$

gayyar noma, 119

gidigo, 150

girka, 109, 117

giwa, 31,55

Gobir, 32

goge, $41,44,45,54,56$, $57,83,120,148$

gora, $5,6,55,70$

goron salla: see barka da salla

gu'da, 67, 131, 134

gunguni, 133,136

gurmi, $43,53,54,55,56$, 57,58

Gwabron Tambari, 32, 33, 36

gwaja, 150

gwangwanin kifi, 55

gwatso, 150

gyan'dama, 5, 6, 55

haki, 55

Hamisu Na Biyar, 92

hannun baya, 20

hannun gaba, 20

hawan bori, 109 hawan daushe, $34,37,64$, $71,84,94,103,109$, 119,121

hawan $\mathrm{k}$ 'aho, 106, 126

hawan kilisa, $64,71,94$, 109,119

hawan salla, 34, 37, 64, $71,74,94,103,106$, $109,111,118,119$, 120,121

hazik'anci, 132, 136

home, 55

hurya, 55

Ibrahim $\mathrm{Na}$ Habu, 45, 108, 144

ice, 55

ido, 55

idon zakara, 55

iska: see iskoki

iskoki, 109, 117, 138, 148

izga, 55

jaka, 56

jaki, 56

jama'iyar neman arziki, 113

Jan Ki'di, 140, 145

jauje, 23, 27, 28, 54, 55, 65,77

jinjina, 133, 146

jita, 44

juya ki'da, 147

juyen take, 147

kacakaura, 7, 97

kacikaura, 7

Kadiriyya, 13

kafar zuba mai, 56

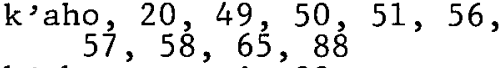

k'ahon tsauri, 88

kai gara, $21,78,80,110$, $116,125,142$

kaka, 116

kakaki, 35, 48, 49, 50, 51, $55,56,58,65,89$, 132,146

kalangu, 14, 20, 23, 24, $25,28,30,42,54,56$, 
kalangu (cont.)

$57,58,71,72,77,78$, $79,81,82,92,93$, $126,132,134,143$, $148,149,150$

kalangun Sarki, 24, 25, 65, 79

kalankuwa, $21,76,80,85$, $88,95,107,108,110$,

kallabi, 56 $120,122,124,127,150$

kambu, 56

kango, 55, 56

$\mathrm{k}$ 'angu, 54,56

k'ank'ara, 56

kan tandu, 56

kanzagi, 26

kara, 56

k'aramar ganga, 18

k'aramar kalangu, 24, 25, 82

$\mathrm{K}$ 'aramar Salla, 10, 16, 18, $36,37,64,71,80$, $107,110,116,117$, $118,120,121,122$, $124,127,128,130,143$

karen Gusau, 4, 70

karen marok'a, 72, 95, 107

karin magana, $3,11,21$, $25,27,30,45,63,73$,

k'aro, 56 $75,123,133$

karuwai, 106

kasam'bara, 7, 47, 52

kaskar karen marok'a, 95

$\mathrm{K}$ 'aura, 8,36

kayan yaji, 57

kazagi $, 6,15,20,21,26$, $31,56,57,58,71,73$, $80,81,82,92,93$, $143,149,150$

kazagin amada, 9

ki'da, 147, 148

ki'di, 147

ki'dan a sha k'afa, 148

$\mathrm{ki}$ 'dan amada, 91, 147

ki'dan bori, 117,148

ki'dan bumbum, 148

ki'dan dundufa, 149

ki'dan daren juma'a: see waza

ki’dan fada, 148 ki'dan fawa, $121,125,148$

ki'dan gayya, 149

ki'dan hawan $k$ 'aho, 121, 126,149

ki'dan jarfa, 149

ki'dan kokawa, 150

ki'dan kufegere, 150

ki'dan kwambe, 148

ki'dan magori, 148

ki'dan maharba, 148

ki'dan mahauta, 74, 111, 148

ki'dan mak'era, 149

ki'dan malamai, 12, 107 , 149

$k i$ 'dan manoma, 149

ki'dan nama: see $\mathrm{ki}$ 'dan fawa

ki'dan noma, 149

ki'dan rawan Gane, 149

ki'dan rawan takai, 149

ki'dan rawan 'yan mata, 150

ki'dan ruwa, 117, 143, 147, 149

ki'dan wasa da kura, 150

ki'dan wanzamai, 149

ki'dan 'yan dambe, 150

$\mathrm{ki}$ 'dan 'yan hoto, 150

ki'dan 'yan kama, 150

ki'dan 'yan kokuwa, 150

ki'dan 'yan mata, 124, 150, 151

ki'dan 'yan tauri, 150

kin-kin-kin, 151

kiranye, 118, 134

kirari

definition, 134

general reference, 3,20 , $21,38,51,62,63,64$, $73,76,83,88,95$, $106,107,109,110$, $111,114,118,119$, $120,121,126,128$, $131,132,134,150,151$

of instruments, 16,18 , $23,29,37,39,41,43$, $50,51,82$

of people, 8, 134

kirgi, 57

kirinya, 57

$\mathrm{k}^{\prime}$ ofa, 55, 57

k'ofar tsarkiya, 56 
k'ofar zuba mai, 57

kokawa, 21, 80, 95, 96, $108,111,120,121$

k'ok'o, 57

kokuwa, 121

kolo, 23, 27, 65, 77, 79 komo, 6, 41, 57, 82, 84 ,

k'oroso, 5

kotso, $28,29,54,55,56$, $57,58,65,79,132$

kuge, $7,65,71$

kukuma, 44, 56, 85, 92,

kumbo, 57 $106,140,144,148$

$\mathrm{k}$ 'ungu, 57

kuntigi, $45,54,55,85,86$

kuntugi: see kuntigi

kuntukun tambari, 31, 32, 35

kuntuku, 4, 18, 25, 29, 30, $55,56,57,58,59,70$, $81,82,92$

kuntukuru, 29

kurkutu, 29 (see also kuntuku)

kurman laya, 57

Kurna, 145

kurtu, 57

kuru, 30,149

kurya, $15,19,20,21,31$,

kuttuku, 29

kwairama, 6, 19, 21, 27, $54,80,81,143,148$, 149,150

kwambe: see a sha k'afa

kwance, 122

kwango, 56

kwanta, 78, 92, 95, 110,

kwarkwaro, 57

$120,121,122,125,126$

k'warya, 8, 91, 115, 140, 147,148

k'waryar goge, 9, 71

k'waryar ki'dan ruwa, 9, 91,149

k'waryar kukuma, 8, 85

lafsuru, 150

lalajo, 7 lalayyo, 150

lele, 137

liko, 57

Lingarai, 32

lugude, 12, 122, 143

ma'abbanci, 134

Ma'ajin Busa, 99

ma'auni, 136

mabusa, 52, 62, 69

macara, 55

Madaki, 8, 37, 71, 87

Madakin Banga, 98, 99

Madakin Busa, 99

Madakin Gardi, 100

Madakin Jauje, 101

Madakin Kakaki, 101

Madakin $\mathrm{Ki}$ 'da, 75, 102

Madakin Rok'o, 99

Madakin Taushi, 103

ma'dauki, 57

Magajin Banga, 65, 74, 98

Magajin Bangan Galadiman Zazzau, 98

Magajin Busa, 64, 65, 86, 87,99

Magajin Kotso, 79, 99

magu'da, 62

magu 'diya , $17,54,58$

maharba, 41, 84, 106, 116

mahauta, 25, 77, 106

mai, 69,98

mai wallafa, 135

mairo dike, 150

maka'da, 62, 69

maka'dan fada, 65

maka'dan gardin kura: see maka,dan mai wasa da kura

maka'dan hakimai, 62, 63

maka'dan mai wasa da kura, 108,126

maka'dan sarakuna, 62,63

maka'dan Sarki, 62, 65

maka'dan 'yan hoto, 73

maka'dan 'yan mata, 73, 80, 110,125

maka'dan 'yan tauri, 31 , $73,106,111,120,128$, 150

maka'di, 58, 69 
Makaman Ki'da, 75, 102

mak'era, 18, 81, 106

mak'ogaro, 58

malamai, $10,41,70,71$, 107,142

Malan Na Buta, 96 (see also 'yan garura)

man gya'da, 58

manoma, 21, 75, 107

Mara'di, 39

Mara'din Kurfi, 81

maratayi, 58

marfi, 58

marok'a, 62, 65, 67, 70, $72,85,93,95,97$, $100,101,105,106$, $107,108,109,110$, $111,113,114,116$, $117,118,119,122$, $123,124,125,126$, 130,132

marok'an baki, 63, 69, 70 , $73,76,78,82,83,89$, $94,95,96,99,110$, $113,116,117,118$, $119,120,121,122$, $126,128,134$

marok'an fada, 65, 109

marok'an hakimai, 62,63 , $64,65,109$

marok'an sarakuna, 62,63 , $64,75,79,109,120$, $123,129,130$

marok'an Sarki, $62,65,66$, $100,103,109,118$,

119,129

marok'i: see marok'a marok'iya, 132

masakin amada, 9

masakin ka'dawa, 9

masarauta: see sarakuna

masarta, 65

masartan hakimai: see

marok'an hakimai

masartan Sarki, 65, 66, 100 masu, 69, 98

masu algaita, 76, 86, 99, 102

masu amada, 91, 115

masu amshi, 66, 73, 75, 76, $77,79,81,82,132$

masu banga, $74,98,99$ masu busa, $62,69,86$

masu bege, 91

masu busan damalgo, 90

masu busan til'boro, 87

masu duma, 75

masu duman girke, 75, 109

masu dundufa: see 'yan dundufa

masu farai, $76,77,86,87$, $89,99,100$

masu ganga, 64

masu gangar algaita, 75 , $86,99,102$

masu gangar fada, 76,77 , $86,87,89,101$

masu gangar noma, 21,76 , $81,89,98,102,107$, $108,110,119,120$, 124,128

masu gangar 'yan mata, 73 , 80

masu garaya, 70, 82, 117

(

masu garayar bori, 82, 109

masu goge, $71,83,100$, $101,106,108,109$, $117,120,124,144$

masu gora, 70, 82, 85, 109, 117

masu gurmi, 83

masu jauje, 77

masu k'aho, 76, 87, 88, 89, 100

masu kakaki, 64, 76, 77, $86,87,89,100,101$

masu kalangu, 70,73, 76, $77,79,80,81,98$, $102,106,108,110$,

$114,116,118,121$, $122,124,125,126$, $127,128,150$

masu kalangun Sarki, 79, 101

masu kasam'bara, 70,82 , $85,109,117$

masu kawo, 66

masu kazagi: see 'yan kazagi

masu ki'da, 62, 69,70

masu ki'dan buta, 70, 107

masu ki'dan kalangu, 77

masu ki'dan kufegere, 73 


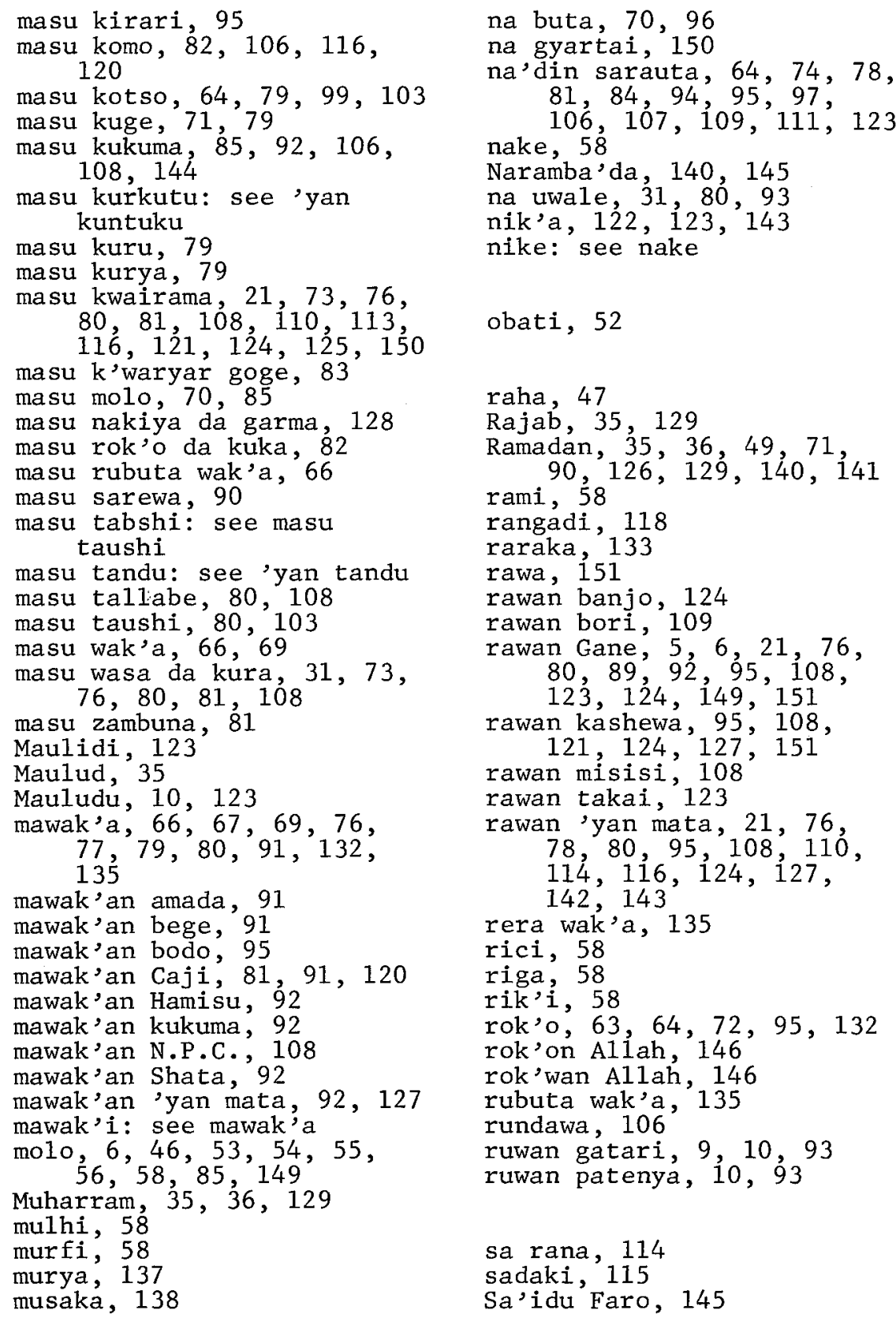


saisaya, 58

sake bugu, 147

Saleh Mai Gambara, 139

Sallar Cika Ciki, 78, 121, 125,126

Sallar Takutufa, 35, 125

Sallar Wowwo: see Sallar Cika Ciki

salo, $31,34,133,147$

samammance, 122

samari, $21,73,77,80,108$

sam'bara, 7

samfara, 58

San K'ira, 65, 76, 94, 95, 99,134

San K'iran Zazzau, 99

sandar gamu, 58

sara, $64,79,87,89,94$, 109

saraki: see sarakuna

sarakuna, $10,64,76,85$, $91,93,105,109$

saran salla: see wazan salla

sarauniyar kyau, 127

sarauta, $71,97,98,99$, $100,101,102,109$

sarewa, 52,90

Sarkin Bamba'dawa, 65, 94 , 99

Sarkin Busa, 20, 64, 65, $88,89,100$

Sarkin Buta, 100

Sarkin Fadan San K'iran Zazzau, 99

Sarkin Farai, 65, 87, 100

Sarkin Gangar Noma: see Sarkin Maka'dan Gangar Noma

Sarkin Gangar Noman Zazzau: see Sarkin Maka'dan Gangar Noman Zazzau

Sarkin Gardi, 66, 100

Sarkin Goge, 100

Sarkin Gogen Tudun Wada, 100

Sarkin Jauje, 65, 77, 101

Sarkin Kakaki, 5i, 64, 65, 89,101

Sarkin Kalangu, 65, 71, 101

Sarkin Karma, 79

Sarkin Kauru, 89, 101
Sarkin Ki'dan Caji, 101

Sarkin Maka'da, 20, 65, 75, $76,86,98,99,101$, 102,117

Sarkin Maka'dan Kotso, 65, 79

Sarkin Maka'dan Gangar Noma , 71, 76, 102

Sarkin Maka'dan Gangar Noman Zazzau, 102

Sarkin Maka'dan Kotso, 103

Sarkin Maka'dan Tudun Wada, 102

Sarkin Mak'era, 197

Sarkin Musawa, 89

Sarkin Sullu'bawa, 36

Sarkin Tambari, $34,37,65$, 103

Sarkin Tabshin Katsina, Alhaji Mamman, 132

Sarkin Taushi, 65, 80, 103

Sarkin Tudun Wada, 100

Sarkin Wak'ar N.P.C., 108

Sarkin Zazzau, 101

sha ki'di, 58

sha'irai, 66

sham'bara, 7

shantu, 10, 11, 106, 143

shantuna: see shantu

sharan fage, 114

Shata, 137 (see also Alhaji Muhamman Shata)

shata, 58

shatan gimi, 150

Shawa1, 121

she'dara, 137

sheme, 55

shera, 66

sheshe, 52

shiri, 133

shirin wak'a, 135

suna, 16, 64, 72, 95, 107, $109,117,125,143$

ta'barya, 59

ta'bi, 143, 151

tabshi, 38

ta'da, 11,59

tafashe, 46

take, 8, 20, 21, 34, 39, $48,51,63,64,73,76$, 


$$
\begin{aligned}
& 77,78,79,80,86, \\
& 106,107,108,109, \\
& 110,118,119,120, \\
& 121,128,132,147, \\
& 149,150
\end{aligned}
$$

taken maharba, 106

taken mahauta, 106

taken mak'era, 107

taken samari, 108

taken sarakuna, 109

tallabe, $27,30,73,80$, $81,93,96,150$

talle, 15, 31, 73, 150

tambara, 55, 59

tambari, 31, 32, 34, 35, $36,37,38,53,54,55$, $57,58,98,103,116$, $123,125,146,147,151$

tambura, 35, 51, 123, 125, 129

Tambura, 34, 36, 65, 89, 103,151

tandu, $11,56,72,149$

tantanin dalo, 59

tarewa, 115

tarihi, 135, 139

tarihin Daura, 139

tashe, 9, 20,93

tashen Azumi, 72, 91, 92, $95,105,106,107,125$, 129,142

tatsuniya, 141

taushi, $20,38,54,55,57$, $58,59,65,80$

tawai, 137

ti1'boro, 48, 49, 52, 53,

til1i, 9 59,87

tillik'o, 52

tillik'oro, 52

totara, 17

toto, 59

tsagiya, 59

tsahi, 59

tsarance, 122

tsarkiya, 59

tsawo, 137

tsinke, 54

tsuma, 118,121

tudara, 17

tuke, 59

tulluwa, 9
Turakin Busa, 99

Turakin Ki'da, 102

turmi, 59, 122

tuwis, 124

turu, 39,59

uwa, 17,59

uwar gida, 17

wak'a, 62, 91, 131, 135

wak'ar abayyana, 80, 92 , 124,141

wak'ar addini, 135, 138

wak'ar amada, 147,149

wak'ar arauye nanaye, 142 , 149

wak'ar asauwara, 142

wak'ar bojo, 140

wak'ar bori, 41, 42, 52, $83,117,135,138$

wak'ar caca, 140

wak'ar da'be, 118

wak'ar gamtsi, 93, 139

wak'ar gidan gwauro, 140

wak'ar Gwamnati, 144

wak'ar gwatso, 143

wak'ar gwauro, 140

wak'ar kishiya, 11, 91, 143

wak'ar macukule, 141

wak'ar mada'ba, 137

wak'ar mata, 143

wak'ar miji, 143

wak'ar nanaye, 142

wak'ar nasha'di, 4, 41, 42, $46,52,70,80,83,85$, $91,132,135,138,139$, 141

wak'ar N.E.P.U., 144

wak'ar N.P.C., 144

wak'ar rawan Gane, 142

wak'ar samari, 141

wak'ar shan giya, 140

wak'ar siyasa, 4, 42, 46, $70,83,85,91,135$, 144

wak'ar soja, 145

wak'ar Takutaha, 138

wak'ar tashi wali, 142

wak'ar tatsuniya, 141

wak'ar uwar miji, 143 
wak'ar yabo, 41, 42, 46, $74,76,77,79,80,81$, $83,84,85,86,91$, $132,135,145,150$

wak'ar 'yan dako, 142 wak'ar 'yan kura, 142 wak'ar 'yan mata, 78, 110 , 139,142

wak'ar yara, 141

wak'e, 135

Wakilin Rok'o, 99

wak'ok'in nasha'di: see wak'ar nasha'di

wallafa wak'a, 135

wanzamai, 143

wasa, $69,71,74,76,77$, $78,79,82,83,84,85$, $86,88,89,90,97,127$

wasan ba'a, 69

wasan hawan k'aho, 78, 106, $121,125,126,149$

wasan kashewa, 83

wasan kura = wasa da kura, 108,126

wasan misisi, 78, 92, 95, $110,120,121,125$, 127,142

wasan N.P.C. or N.E.P.U., $83,86,96,108,124$, 127

wasan 'yan hoto, 120, 121 , 127,150

wasan 'yan tauri, 74,88 , $111,128,150,151$

Watan Azumi, 35, 71, 87, $90,93,107,129$

Watan Azumin Duk Gari, 35

Watan Azumin Tsoffi, 35, 129

Watan Takutaha, 129

Watan Takutufa, 129

Watan Wowwo, 129

wawa, 66

waza, $64,79,87,89,94$, $109,129,130$

wazan salla, 64, 71, 109, 121,130

Waziri, 87,88

Wazirin Banga, 98, 99

Wazirin Buta, 100

Wazirin Ganga, 75, 101

Wazirin Ki'da, 102
Wazirin Rok'o, 99

Wazirin Kotso, 99

Wowwo, 35, 36, 129

wuri, 59

'yan, 69

'yan agalanda, 96, 118

'yan amshi, 66, 132

yan amsawa, 66, 132

yan bori, 109,117

'yan 'dai-'dai, 31, 34

'yan daji, 9,93

'Yan 'Daka, 36

'yan damalgo, 90

yan dambe, 78, 106, 109

'yan dundufa, 18, 81, 107

'yan farauta, 106

'yan fawa, 106

'yan galura, 93, 96

yan gambara, $25,31,72$, $80,93,96,139$

'yan garura, 6, 70,96, 97, 100,108

'yan hoto, 73, 76, 110, $119,120,127,128$, 150 (see also wasan 'yan hoto)

'yan jarfa, 31, 81

'yan kacikaura, 7, 96, 97

'yan kama, 22, 93, 140, 150

'yan kashin kasuwa, 81

'yan kar'bi, 66

yan kazagi, 73, 76, 80, $81,89,96,110,119$, $120,121,124,128$

'yan k'ira, 95

'yan k'odago, 147, 151

yan kokawa, 44, 110,150

'yan kokuwa, 44

'yan kuntigi, 85

'yan kuntuku, 70, 73, 78, $81,114,122,124,125$, 127

'yan k'warya, 71, 85, 91, $108,109,117$

'yan k'waryar goge, 83

'yan ma'abba, 95, 134

'yan magana, 96, 97

yan mata, $21,73,77,80$, 110

'yan sanduna, 59 


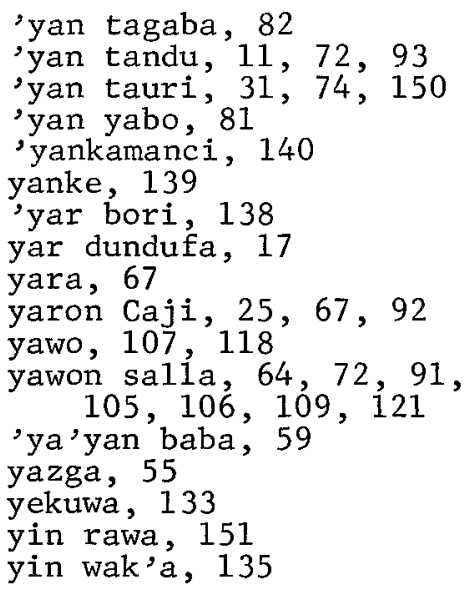

zabaya: see zabiyoyi

Zabayar Sarki, 67, 94 zabiyoyi, $65,67,91$, 120

zaga, 60

zaiga, 60

zambo, 11, 72, 96, 135, 139,143

zambuna, 38,39

zare, 60

zari, 12

zaure, 115

zauren tambari, 32

zikiri, 13

zobe, 60

zuga, 132

Zul Hajji, 35, 116

zunguru, 12, 149 



\section{English-Hausa Index}

AEROPHONES - see under clarinets, flutes, oboes, trumpets

BELLS, clapperless - kuge: $7-8,25,65,71$

performers on - masu kuge: $8,71,79$

CHORDOPHONES - see under lutes

CLAPPERS, plaque - ruwan gatari: 9,93 ruwan patenya: 10,93

performers on - 'yan daji: 9

CLAPPERS, ring - zari: 12

CLAPPERS, vessel - sambani: 10

CLARINETS - dama1go: 48-49, 90, 93

performers on - 'yan $\frac{\text { damalgo }}{90}=\underline{\text { masu busan damalgo: }}$ 49,

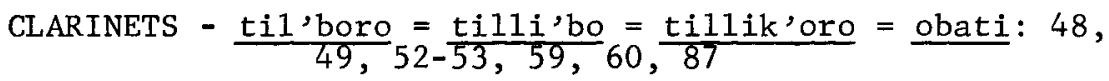
performers on - masu busan til'boro: 87

CLARINETS, parts of:

body - damalgo: 48 til'boro: $52,53,59$

reed - belu $=$ beli $: 52,53$

resonance chamber - $\mathrm{k}^{\prime} \mathrm{ok}$ 'o $=\underline{\mathrm{k}^{\prime} \mathrm{ok}^{\prime} \mathrm{uwa}}: 48$

thread - zare: 52,60 


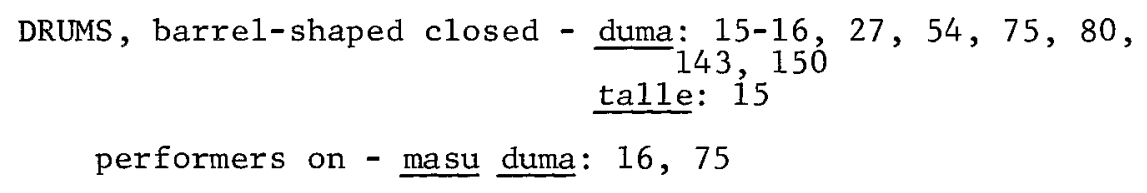
DRUMS, barrel-shaped closed - $\frac{\text { duman }}{\text { duma: }} \frac{\text { girke: }}{16}: 16,27,54,75$ dumanya: 16

performers on - masu duman girke: 75, 109
DRUMS, cylindrical closed - dundufa $=$ dodara $=$ dumfa $=\frac{\text { totara }}{30}=\frac{\text { tudara: }}{55}$ 17-18, 27 , $30,54,55,56,57,58$ $59,81,143,149,750$ uwar gida: $17-18$ duma : $\frac{\text { lda }}{17-18}$ magu'diya: $17-18 \quad 4$ dundufa: $17-18$ 'yar dundufa: $17 \cdot 18$

performers on - 'yan dundufa $=$ masu dundufa: 18,30 , $81,107,145$

DRUMS, cylindrical closed - turu: 39

DRUMS, cylindrical double membrane - badujala: 12-13

DRUMS, cylindrical double membrane - ganga: $x, 8,18-22$,

$30,37,54,55$, $56,57,58,59-$ $60,92,132,149$

performers on - masu ganga: 64

DRUMS, cylindrical double membrane - gangar algaita: $\frac{28}{20} \frac{18}{48}, 63$, 75,81

performers on - masu gangar algaita: $75,86,99,102$

DRUMS, cylindrical double membrane - gangar $\frac{\text { Caji }}{25}, \frac{19}{82}, 20$, 
DRUMS, cylindrical double membrane - gangar $\frac{\text { fada: }}{48}, \frac{19}{49}, 50,51$, $58,63,65,71$, $76,133,148$

performers on $-\frac{\text { masu }}{89,102}$ fada $: 76-77,86,87,88$,

DRUMS, cylindrical double membrane - gangar noma

$$
\begin{gathered}
=\frac{\text { baragada }}{6,19,20,21,}=\frac{\text { fya'de: }}{27,30,54,71} \\
73,76,81,141, \\
149,150
\end{gathered}
$$

performers on - masu gangar noma: $21,76,79,81,84$, $110,119,120,124,128$

DRUMS, cylindrical double membrane - kurya: 15-16, 18-19,

$$
27,21,22,25,
$$

performers on - masu kurya: 79 DRUMS, cylindrical double membrane - kwairama: $6,719,21$, $81,141,143$,

performers on - masu kwairama $=$ maka'dan 'yan mata: $21,73,76, \frac{20,81,108,110,114}{\text {, }}$ $116,121,125,150$

DRUMS, cylindrical double membrane $-\frac{\text { tallabe }}{25}=$ gambara: $73,80,81,93$, 96,150

performers on - masu tallabe: 80,108

DRUMS, cylindrical double membrane - turu: 39

DRUMS, frame circular - bandiri: 13 
168 / GLOSSARY OF HAUSA MUSTC

DRUMS, goblet closed - zambuna: $39,63,81$

performers on - masu zambuna: 81

DRUMS, hourglass double membrane - 'dan kar'bi: 4, 14-15, $23,24,25,30,42$,
$54,56,58,78,92$,
124,143

DRUMS, hourglass double membrane - jauje: $\frac{23,24,27-28,7}{54}, 55,63,65,77$ performers on - masu jauje: 28, 72, 90, 101, 129

DRUMS, hourglass double membrane - kalangu: 4, 20, 24, 23$26,30,42,54,55$, $56,57,58,59,71$, $72,73,75,77,79$, $81-82,92,93,126$, $132,134,141,143$, 148,150

performers on - masu kalangu: $25,26,30,70,73,75$, $76,77,81,92,96,98,102,106$, $108,110,114,116,118,121,122$, $124,126,127,128,145,150$

DRUMS, hourglass double membrane - kalangun Caji: 63

DRUMS, hourglass double membrane - kalangun Sarki: 24, 25, $28,65,78-79$

performers on - masu kalangun Sarki: 25, 78-79, 101

DRUMS, hourglass double membrane - $\frac{\text { k'aramar }}{25,78,7 \text { langu: }} 24$,

DRUMS, hourglass double membrane - kolo: $23,25,28,65$,

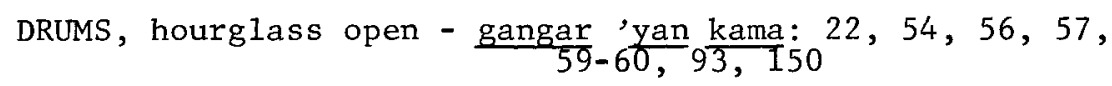
performers on - 'yan kama: 22 
DRUMS, hourglass open - kazagi $=$ kanzagi: $6,15-16,18$, $20,21,25,26-27,31,56,57$, $58,59-60,63,71,73,75,80$, $81,82,92,93,141,143,149$, 150

performers on - 'yan kazagi $=$ masu kazagi: $27,69,73$, $12 i, 124,128$

DRUMS, hourglass open - kotso: $28-29,54,55,56,57,58$, $59-60,63,65,79,132$ performers on - masu kotso: $29,64,74,75,79,86$, 99,103

DRUMS, hourglass open - kuru: 30,149

performers on - masu kuru: 79

DRUMS, kettle - bandiri: 13

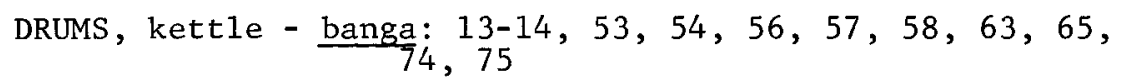
performers on - masu $\frac{\text { banga: }}{129} 14,74-75,87,98,99$,

DRUMS, kettle - kuntuku $=$ kurkutu $=$ kuttuku $=$ kuntukuru: $4,18,25,29-30,55,56,57,59,75$, performers on - 'yan kuntuku $=\frac{\text { masu }}{78,81-82}, \frac{\text { kuntuku: }}{114}, 70,73$, $122,124-125,127$

DRUMS, kettle - taushi $=$ tabshi: $38-39,53,54,55,57$, $58,59,60,63,65,80$

performers on - masu taushi: $39,80,103,129$

DRUMS, kettle - talle: $31,73,150$

performers on - maka'dan 'yan tauri: $31,73-74,111$, 
170 / GLOSSARY OF HAUSA MUSIC

DRUMS, kettle - tambari: ix, 31-38, 51, 53, 54, 57, 58, $59,60,65,89,98,103,114,116$, $121,123,125,129,132,146,147$,

151

DRUMS, parts of:

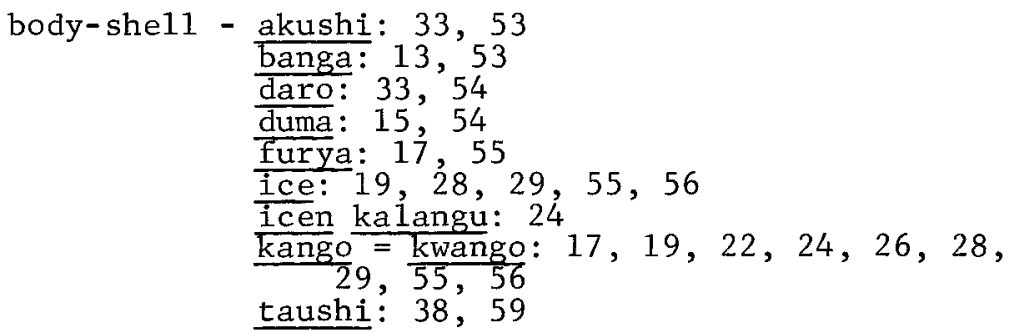

hole in body-shell - ido: $17,29,38,55$

kafar zuba mai $=\frac{\text { k'ofar }}{55}$ zuba mai:

rami: 33,58

jingle - ceba: 20,54

lacing holes - k'ofar tsarkiya: 28,57

lacing needle - cinki $=$ tsinke: 17,54

lacing ring - awara: 13, 38, 53

$\frac{\text { kirinya }}{\text { riki: }}=\frac{\text { zobe }}{58}: 33,57,60$

lacing thong - rici: 14, 58

tsarkiya $=\frac{\text { tsirkiya: }}{20} 18,19,22,24$, $\frac{\text { turu: } 26,59}{26,33,38,59,77,84}$ 


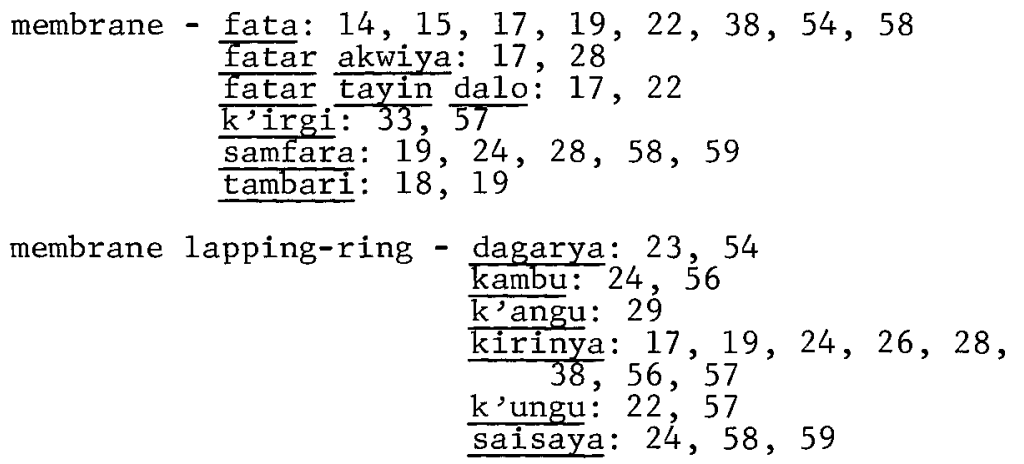

oil for body-shell - man gya'da: 17, 58

oil and spice for body-shell - kayan yaji: 33, 57

open end of body-she11 - mak'ogaro: 28, 58

plug for hole in body-shell - 1iko: 14, 57 marfi: 33,58 toto: 18,59

$\begin{aligned} \text { seeds in body-shel1 - } & \text { 'dan kawo: } 23,54 \\ & \frac{i \text { don }}{\text { 'ya'yan baba }: 19,55} \text { baba: } 24,59\end{aligned}$

sewing thread for membrane - tuke: 24, 59

snare $-\underline{\text { zaga }}=\underline{\text { zaiga }}: 19,22,27,28,38,60$

wax layer on membrane - dank'o: $38,54,58$ $\underset{58}{\text { nake }}=\frac{\text { nike: }}{79} 14,28,38,54$,

DRUMS, performance techniques - hannun baya $=$ taushi: 20 hannun gaba: 20

taushi: 20

ti11o: 25

FLUTES $-\underline{\text { sarewa }}=\underline{\text { sheshe }}=$ mabusa $: 52,90$

performers on - masu $\frac{\text { sarewa }}{69,90}=$ masu busan sarewa: 52 , 
FRICTION STICKS - sam'bara $=\frac{\text { kasam'bara }}{41,47}=$ sham'bara $: 7$, performers on - masu kasam'bara: $70,82,85,109,117$

IDIOPHONES - see under bells, clappers, friction sticks, percussion tubes, percussion vessels, plucked idiophones, ratties

INSTRUMENTALISTS :

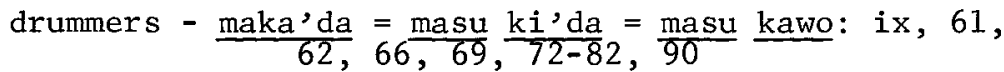

idiophonists - maka'da $=$ masu ki'da: ix, 61, 62, 70-72

lutenists - $\underline{\text { maka'da }}=\underline{\text { masu }} \underline{\mathrm{ki} \text { 'da }}: 61,62,82-86$

wind players - mabusa $=$ masu busa: ix, 61, 62, 69, 76,

INSTRUMENTAL MUSIC:

a11 types - bushe-bushe da ki'de-ki'de: 132,146

drums, chordophones, idiophones - ki'da: ix, 62, 147

wind instruments - busa: ix, 146 INSTRUMENTAL TEXTS - take: $8,20,21,23,34,39,48,51$, $87,88-89,89,105,106,107$, $108,109,110,111,116,118$, $119,120,121,128,132,147$, 149,150

LUTES, bowed - goge: $9,25,41-43,44,45,54,55,56,57$, $59,71,83,84,93,120,144,148$

performers on - masu goge: $42,69,71,78,83,83-84$, $85,100,106,108,109,117,120$, 124

LUTES, bowed - $\frac{\text { kukuma: }}{92}: 8,25,44,45,46,59,71,85,86$, $92,106,140,144,148$ 
performers on - masu $\frac{\text { kukuma: }}{108,144} 45,71,83,85,92,106$, LUTES, plucked - garaya: 6, 7, 40-41, 44, 45, 46, 53, 54, $54-55,56,57,58,59,82,83,148$,
149

performers on - masu garaya: $41,70,82-83,84,117$

LUTES, plucked - gurmi: 44, 53, 54-55, 56, 57-58, 59, 84 performers on - masu gurmi: 44,84

LUTES, plucked - jita: 44

LUTES, plucked - komo $=$ babbar garaya: $6,41,57,82,84$, performers on - masu $\frac{\text { komo: }}{45} 41,82,84,106,116,120$,

LUTES, plucked $-\frac{\text { kuntigi }}{86,}=$ kuntugi: 144 45-46, 54, 55, 59, 85performers on - 'yan kuntigi $=$ masu kuntigi: 46,85 ,

LUTES, plucked - molo: 6 i49 46-47, 53, 55, 56, 58, 59, 85, performers on - masu molo: $47,70,85$

LUTES, parts of:

$$
\begin{aligned}
& \text { bow }-\underline{\text { izga }}=\underline{\text { yazga }}=\underline{\text { tambara }}: 42,55,59 \\
& \text { bridge }-\frac{\text { jaki: }: 42,44,56}{\text { kara }}: 44,56 \\
& \text { jingle - } \text { ceba }: 40,45,54 \\
& \text { neck - gora: } 45,46,55 \\
& \text { plectrum - farke }=\text { farko: }: 40,54
\end{aligned}
$$




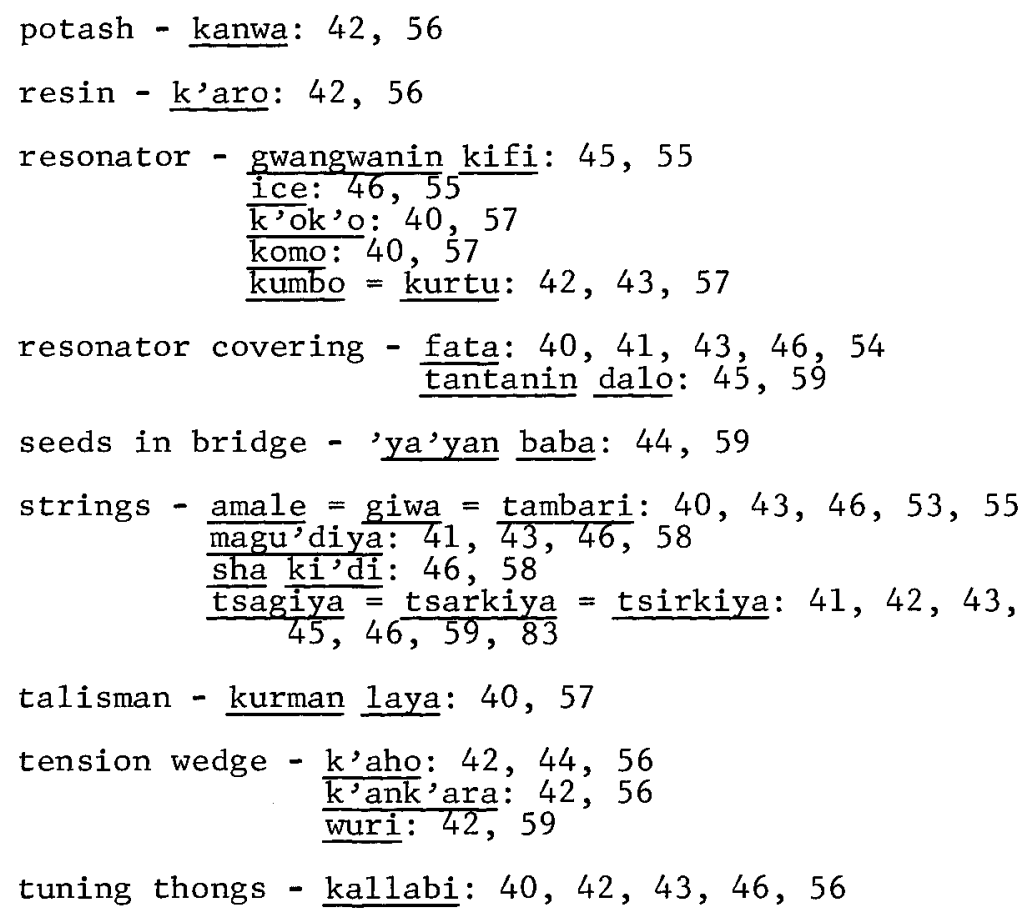

MEMBRANOPHONES - see under drums

MUSIC, professiona1 $-\frac{\text { rok'o }}{95}=\frac{\text { garam }}{132-133}=$ zuga: $: 63,64,72$,

MUSICIANS, individua1s:

Audu Karen Gusau: 70

Audu Yaron Goge: 42, 144

Caji, Dogara: 136

Caji, Hamisu: 136

Caji, Hamza: 82, 91, 136

Caji, Ibrahim 'Dan Mani: 82, 136

'Dan Ala1o: 139

'Dan Anace: 109, 118

'Dan Dawo, Aliyu: 145

'Dan Duna, Mai Kur'di: 86

'Dan K'wairo: 145

'Dan Maraya, Sarkin Kotso: 139

'Dan Maraya Mai Kuntígi: 86, 139, 144 
'Dan Saraki, Ali: 45, 82, 144

Dodo Mai Tabshi: 145

Faro, Sa'idu: 145

Hamisu Na Biyar: 92

Jan Ki'di: 140,145

Kurna: 145

Liyo, Garba: 42,144

Muhamman, Sarkin Tabshin Katsina: $80,132,140$

$\mathrm{Na}$ Habu, Ibrahim: 45, 108, 144

Naramba'da: 140,145

Saleh Mai Gambara: 139

Shata, Alhaji Muhamman: $25,77,82,92,93,132,137$, $139,140,145,151$

MUSICIANS, official - maka'dan Sarki = marok'an Sarki

= masartan Sarki maka'dan fada

$=$ marok'an fada: $8,14,20, \frac{128,29}{}$, $39,50,51,62,63,65,66,71$, $74,76,77,87,94,99,100$, $101,102,103,109,118,119$, 130

MUSICIANS, official - maka'dan sarakuna $=$ marok'an sarakuna $=$ masartan sarakuna: $8,14,20,28$, $29,39,48,50,51,62,63-64$, $65,66,71,74,75,77,79,80-$ $81,86,88,90,94,99,100$, $101,102,103,109,120,123$, 130

MUSICIANS, official titles of:

Bikon Tambari: 98, 103

Ciroman Bamba' dawa: 100

Ciroman Banga: 99

Ciroman Jauje: 101

Ciroman Taushi: 103

'Dan Galadiman Bamba'dawa: 100

'Dan Galadiman Ki'da: 102

'Dan Home: 100, 101

Dunkan Bamba'dawa: 100

Galadiman Banga: 99

Galadiman Rok'o: 99

Ma'ajin Busa: 99

Madakin Banga: 98

Madakin Busa: 99

Madakin Gardi: 100

Madakin Jauje: 101

Madakin Kakaki: 101 
Madakin $\mathrm{Ki}$ 'da: 75, 102

Madakin Rok'o: 99

Madakin Taushi: 103

Magajin Banga: $14,65,74,98,98-99$

Magajin Busa: $48,49,64,65,86,87,99$

Magajin Kotso: 79, 99, 103

Magajin Tambari: 98

Makaman Ki'da: 75, 102

Mawak'an N.P.C.: 108

San K'ira: 63, 65, 76, 94, 95, 96, 99

Sarkin Bamba, dawa: $65,94,99-100$

Sarkin Busa: 50, $51,64,65,88,89,100$

Sarkin Buta: 96, 100

Sarkin Fadan San K'ira: 99

Sarkin Farai: $: 65,87,100$

Sarkin Gangar Noma: 21, 71, 76, 102

Sarkin Gardi: 100

Sarkin Goge: 42,100

Sarkin Jauje: $65,77,101$

Sarkin Kakaki: $51,64,65,89,101$

Sarkin Ka1angu: $65,71,101,102$

Sarkin Ki'dan Caji: 101

Sarkin Maka'da: 20, 25, 48, 65, 71, 75, 76, 86, 89, $98,99,101-102,117$

Sarkin Maka'dan Kotso: 65, 79, 99, 103

Sarkin Tabshi: $65,80,103$

Sarkin Taushi: $65,80,103$

Sarkin Tambari $=$ Tambura: $34,37,65,98,103,151$

Sarkin Wak'ar N.P.C.: 108

Turakin Busa: 99

Turakin Ki'da: 102

Wak'ilin Rok'o: 99

Wazirin Banga: 98,99

Wazirin Buta: 96,100

Wazirin Ki'da: 102

Wazirin Kotso: 99

Wazirin Rok'o: 99

Zabaya: $65,69,94$

MUSICIANS, professional - marok'a $=$ masarta: $62,63,65$, $66,67,68,70,72,73,84$, $87,90,91,93,95,97,100$, $101,105,106,107,108-109$, $110,111,114,115,116$, $117,118,119,122,123$,

$124,125,126,130,132$

OBOES - $\underline{\text { algaita }}=$ raha: $18,20,47-48,53,55,56,57,59$, $63,75,86-87,132$ 


$$
\text { performers on - masu } \frac{\text { algaita: }}{87,98,74,75,76,79,86-}
$$

PERCUSSION TUBES - shantu: 10-11, 106, 143

PERCUSSION TUBES - zunguru: 12, 149

PERCUSSION VESSELS - $\frac{k \text { 'warya: }}{147}, 148,25,42,91,115,140$,

$$
\begin{aligned}
& \text { performers on - 'yan k'warya: 71, } \\
& 109,117 \text {, }
\end{aligned}
$$

k'waryar goge: 9, 42,71

$$
\text { performers on - 'yan } \frac{k^{\prime} \text { waryar }}{\text { goge }}: \frac{124,124}{83,}
$$

$\frac{k^{\prime} \text { waryar }}{147}, \frac{k i^{\prime} \text { dan }}{149}$ ruwa: 9, 91, 143,

k'waryar kukuma: $8,71,85$

PERCUSSION VESSELS - tandu: $11,56,72,149$

$$
\text { performers on - 'yan tandu: 11, } 72
$$

PERCUSSION VESSELS - turmi: 11-12, 59, 122

PERFORMANCE, occasions of:

$$
\begin{aligned}
& \text { dry season tours - cin rani }=\frac{\text { yawo: }}{117-118,123} \text { 93, 107, 109, 110, } \\
& \text { occupational activities - bago: } 84,106,116 \\
& \text { da'be: } 118,143 \\
& \text { daka: } 143 \\
& \text { gayya: } 21,76,95,96,105 \text {, } \\
& 149,108,119,120,127 \text {, } \\
& \text { lugude: } 12,122,143 \\
& \text { nik'a: } 122,123,143 \\
& \text { tawai: } 137
\end{aligned}
$$




$$
\begin{aligned}
& \text { public entertainments - ajo: } 78,83,85,95,108,113 \\
& \text { a sha } \text {,'afa: }^{\prime} 21,38,78,80 \text {, } \\
& \text { bori: } 7,42,70,82,83,93 \text {, } \\
& 149,109,117,127,148 \text {, } \\
& \text { dambe: } 74,78,95,96,106 \text {, } \\
& 108,109-110,111,118 \text {, } \\
& 120-121,150 \\
& \text { kai gara: } 21,78,80,110 \text {, } \\
& 125,142 \\
& \text { kokawa: } 21,80,95,96,108 \text {, } \\
& 110-111,120-121 \text {, } \\
& \text { kwanta: } 78,92,95,110,120 \text {, } \\
& 122,125,127 \\
& \text { rawan kashewa: } 42,83,95 \text {, } \\
& \text { rawan 'yan mata: } 21,76,78 \text {, } \\
& 80,95,108,110,114 \text {, } \\
& 121,124-125,127,143 \\
& \text { wasa } \frac{\text { da }}{108} \frac{\text { kura }}{126} \text { wasan kura: } 21 \text {, } \\
& 108,126,150 \\
& \frac{\text { wasan hawan }}{121} \frac{\mathrm{k} \text { 'aho: }}{125,126}, 149,106 \text {, } \\
& \text { wasan misisi: } 78,93,95,108 \text {, } \\
& 110,121,125,127,142 \\
& \frac{\text { wasan }}{96} \frac{\text { N.P.C. . /N.E.P.U. }}{108,}: \frac{124,127}{124,} 86 \text {, } \\
& \text { wasan ' } y a n \text { hoto: } 21,110,120 \text {, } \\
& 121,127-128 \\
& \text { wasan 'yan tauri: } 74,88,111 \text {, } \\
& 128,150-151
\end{aligned}
$$

religious celebrations and occasions - 
Watan $\frac{\text { Azumi }}{7}=$ Ramadan: 35,49 , $71,87,90,92-93,107$ $126,129,140,141-142$

Watan Azumin Tsoffi: 35,129

Watan Takutufa: 129

\section{zikiri: 13}

secular celebrations - aure: $16,18,64,72,95,107$, $109,114,117,127,142$, 143

buki: $64,70,71,72,74,76$, $78,80,81,83,84,85$, $86,91,92,94,95,96$, $105,106,107,108,109$, $110,111,113,115-116$, $117,122,125,128,142$, 147

kalankuwa: $21,76,80,85,88$, $95,105,107,108,110$, $120-121,122,125,127$

Rawan Gane: $5,6,21,76,80$, $89,92,95,108,123-124$, $14 i, 149,151$

Rawan Takai: 170

Suna: $16,18,64,72,95,107$, $109,117,125,143$

Watan Wowwo:' 35,129

state celebrations and official occasions daba: 74, 111, 118

gaisuwar juma'a: $64,81,107$,

hawan daushe: $34,37,64,71$, $84,94,103,109,119,121$ hawan kilisa: $64,71,94,108$, 119

hawan Sa11a: $34,37,64,71$, $74,84,94,103,106,109$, $111,118,119,120,121$

na'din sarauta: $64,74,78$, $81,84,94,95,96,97-98$, $106,107,109,111,123$ rangadi: $109,118,123$ sara = waza: $64,71,79,87$, $88,89,94,109,129$ wazan Salla: 64, 109, 121, 130 yawon Sal1a: $64,72,91,105$, $106,107,109,121,130$ 
180 / GLOSSARY OF HAUSA MUSIC

PERFORMANCE, patrons of:

barbers - wanzamai: 147,149

blacksmiths - mak'era: 18, 81, 107, 145, 147, 149

boxers - 'yan dambe: 78, 106, 109-110,134, 147, 150

butchers - mahauta: $25,77,106,145,147,148$

clerics - malamai: $10,12,41,70,70-71,74,107$,

district heads - hakimai: 63,64

emirs - sarakuna: 63,64

farmers - manoma: $21,76,105,107,147,149$

girls - 'yan mata: $21,73,77,80,110,147,150$

harlots - karuwai: 72, 82, 83, 85, 85-86, 96, 106

hunters - maharba: $41,82-83,84,106,116,144,147$,

men immune to harm from metal and other hard objects

- 'yan tauri: $31,73-74,93,111,128,145,150$

merchants - attajirai: 85, 91-92, 93, 105

musicians - marok'a: 72, 107

officials - sarakuna: $10,20,63-64,75,85,91,93$,

political parties - N.P.C. and N.E.P.U.: 108

possession dancers - 'yan $\frac{\text { bori: }}{138}$ 70, 83, 93, 109, 117,

sherifs - sharifai: 147

strongarm conjurers - 'yan hoto: 21, 73, 76, 93, 110, $119,120,127,128,147,150$

wrestlers - 'yan kokuwa: $44,84,110,147,150$

wrestlers with hyenas - masu ${ }_{108}$ wasa da kura: $21,73,76$,

youths - samari: $21,73,77,80,108,147$ 


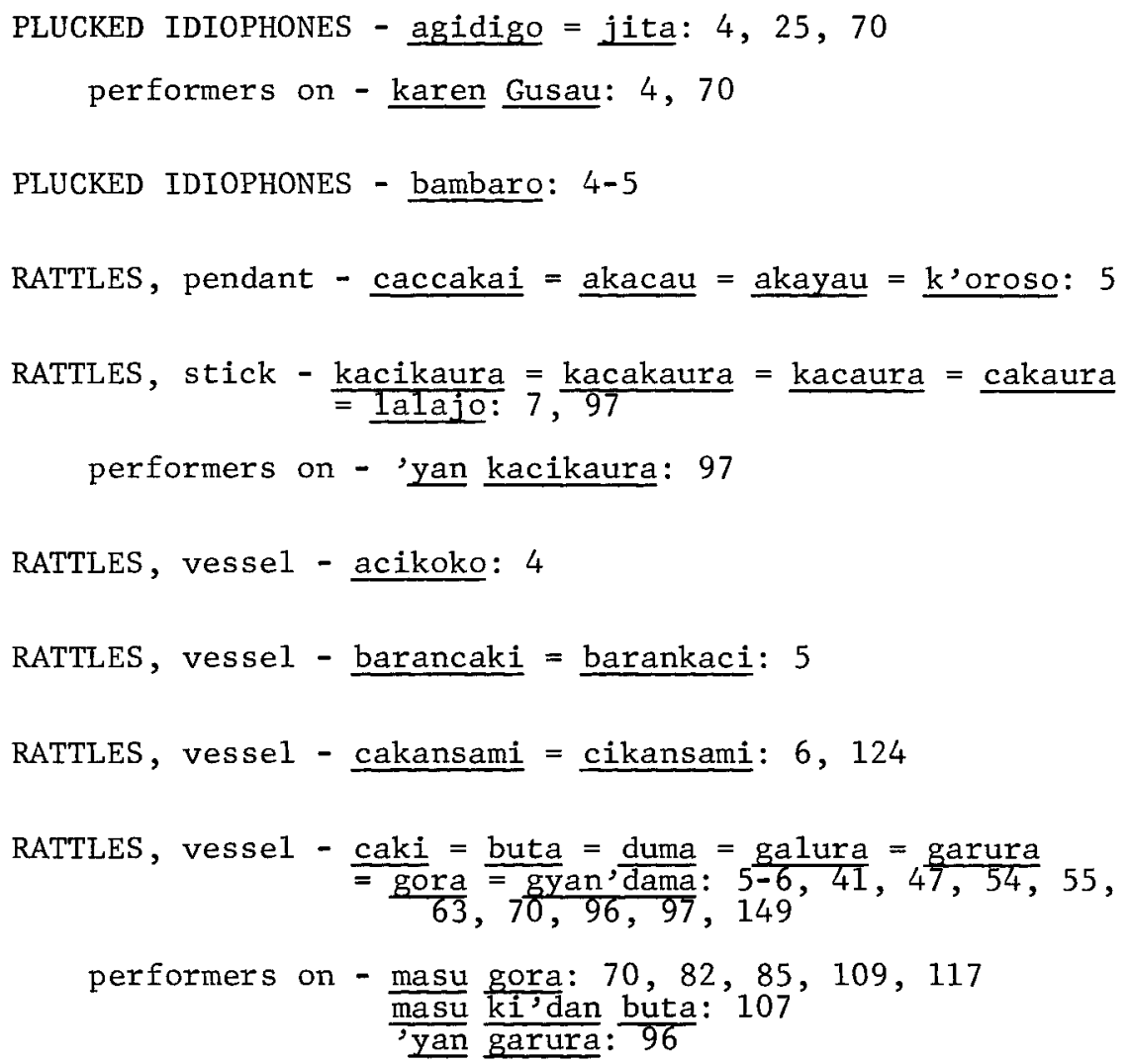

TRUMPETS, meta1 - kakaki: $8,20,35,48,49,50,50-52$, $55,56,58,59,63,65,89,100$, 132,146

performers on - masu $\frac{\text { kakaki: }}{89-90,1}$ i01 $64,76,86,87-88$,

TRUMPETS, natural - bututu: 48

TRUMPETS, animal horn - $\frac{k^{\prime} \text { aho: }}{65}, 20,49,89,50,51,57,58,59$, performers on - masu k'aho: $50,76,87,88-89,89$ 
TRUMPETS, wooden - $\frac{\text { farai: }}{59}, 20,48,48,50,51,54,55,57,58$, performers on - masu $\frac{\text { farai: }}{99,100} 49,76,86,87,88,89$,

TRUMPETS, parts of:

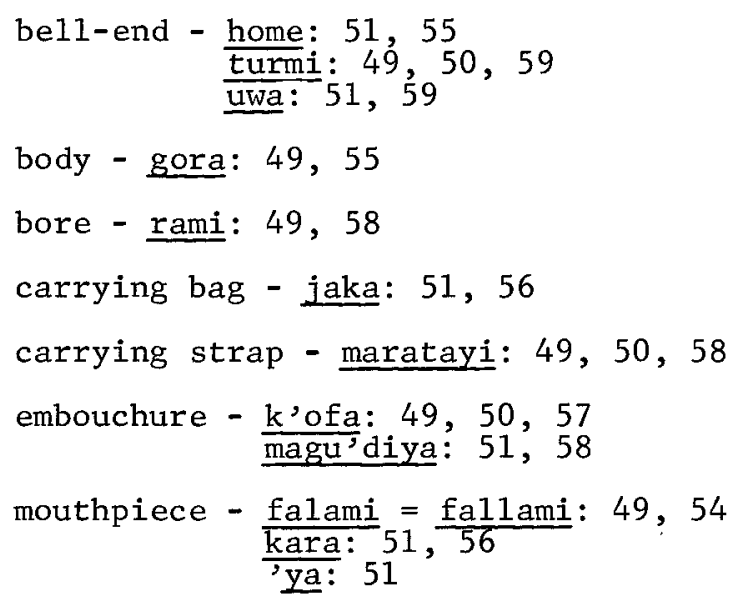

VOCALISTS, acclamators - marok'an baki: $61,63,70,73$, $76,78,82,83,89,94-95$, $96,99,110,114,116,117$ $118,119,120,121,122,126$, $128,134,147$

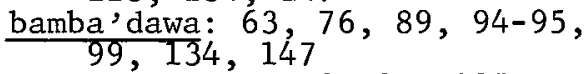

karen marok'a: $72,95,107$

kaskan karen marok'a: 63,95

masu kirari $=\overline{\text { San } \mathrm{K}^{2}}$ ira $=$

='yan k'ira: 63, 95, 134

mawak' an bodo: 95

'yan agalanda: $: 63,95,96,118$

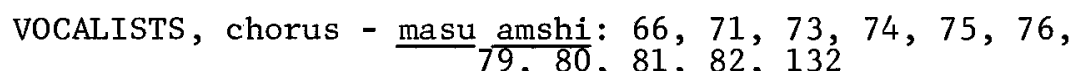

VOCALISTS, singers - $\frac{\text { mawak'a: }}{80} 61,66-67,71,74,76,79$, $80,91-94,132,135$ karen Gusau: 4,74 mawak, an Amada: $71,91,115,147$ 


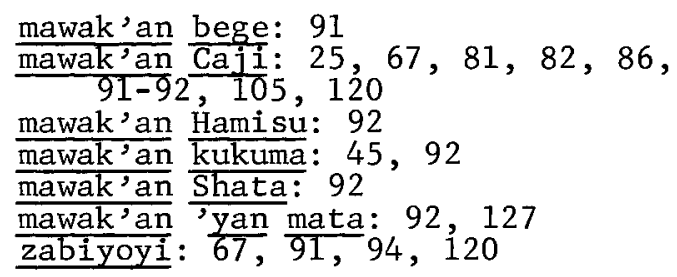

VOCALISTS, talkers/singers - 'yan magana: 61, 96-97 masu wasa da kura: $31,80,81$ na uwale: $31,80,93$

Jyan daji: 9,93

'yan gambara: $25,31,72,78$, $80,81,93,96,139$ 'yan garura: $6,74,93,96-$ $97,100,108$ 'yan jarfa:' 31

yan kacikaura: 7, 96-97

'yan kama: 22, 93, 140, 150

'yan kashin kasuwa: 81

'yan tagaba: 82

'yan tandu: $11,72,93$

VOCALISTS, ululators - magu'da: 62,134

VOCAL MUSIC, acclamatory/epithetica1

texts - kirari: $8,20,22$,
$29,37-38,39$,
$41,43,50,51-$
$52,62-63,64$
$65,76,80,82$
$83,88,95,106$
$107,109,110$
$111,114,118$
$119,120,121$
$126,128,132$
134,150

VOCAL MUSIC, challenges - kiranye: 131,134

VOCAL MUSIC, proclamations - gangami: 131, 133-134

VOCAL MUSIC:

song - wak'a: ix, $62,67,91,131,135$ 


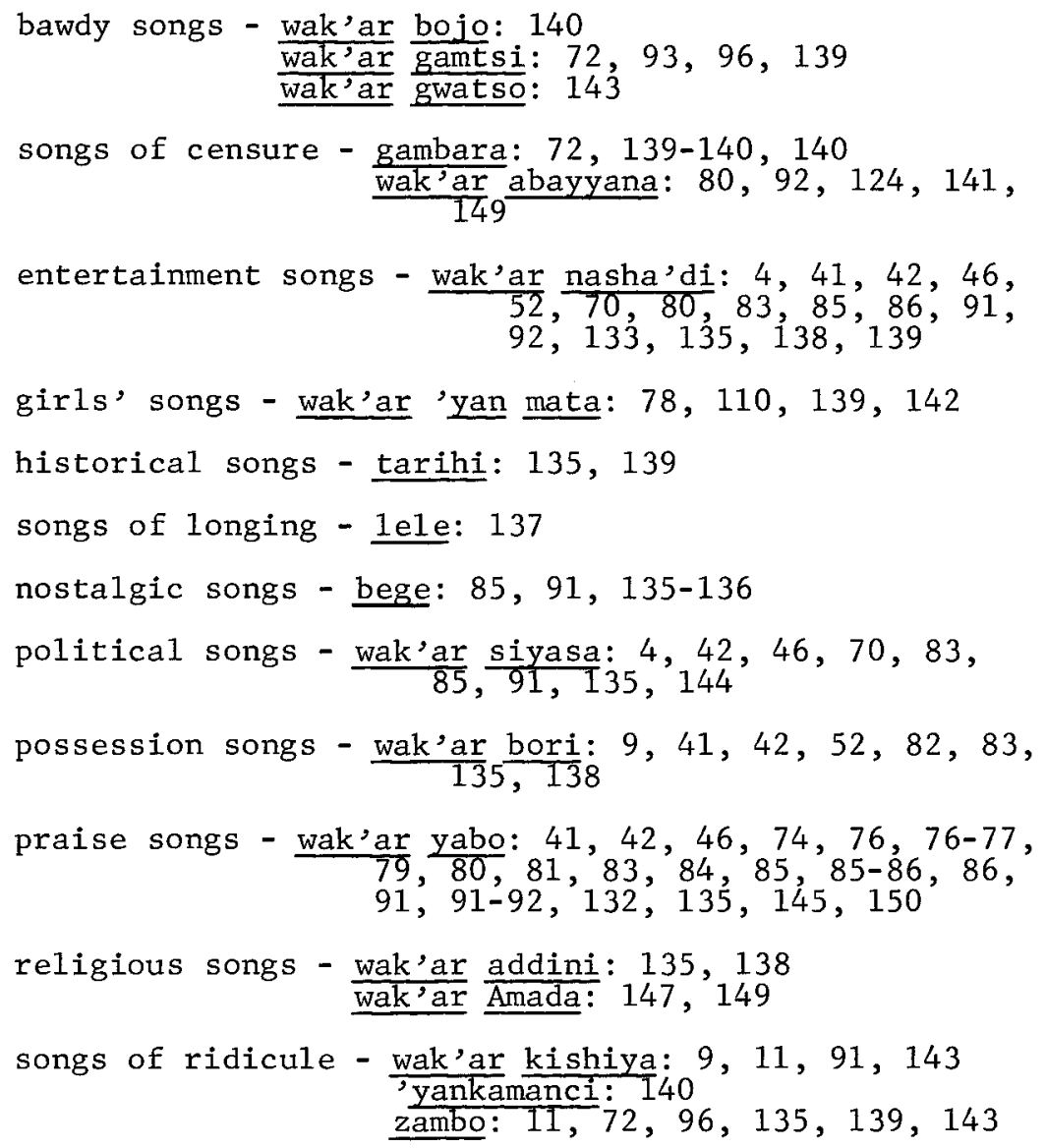

VOCAL MUSIC, ululation - gu’da: $62,67,131,134$ 


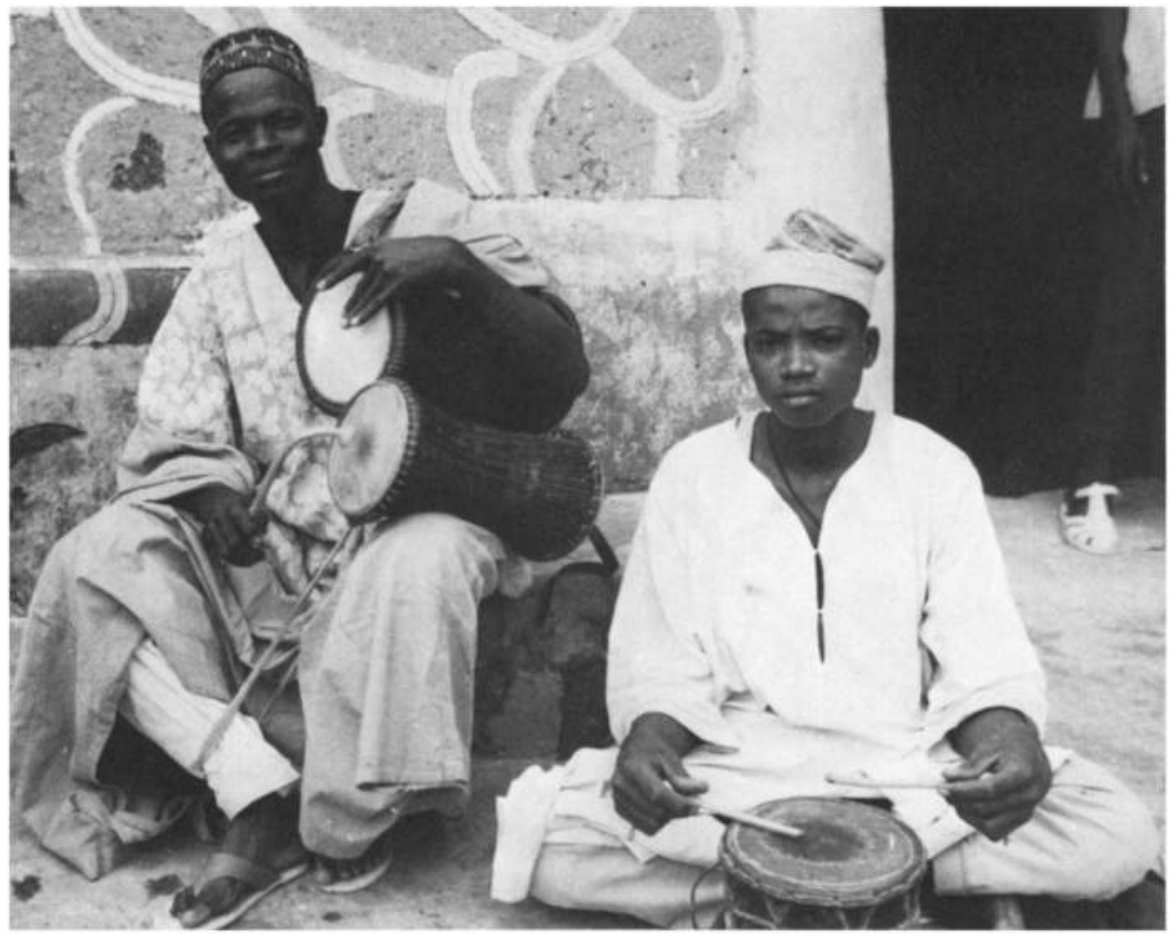

Figure 1. Marok'a of Zaria city drumming on kalangu/'dan kar'bi (left) and kuntuku (right.)

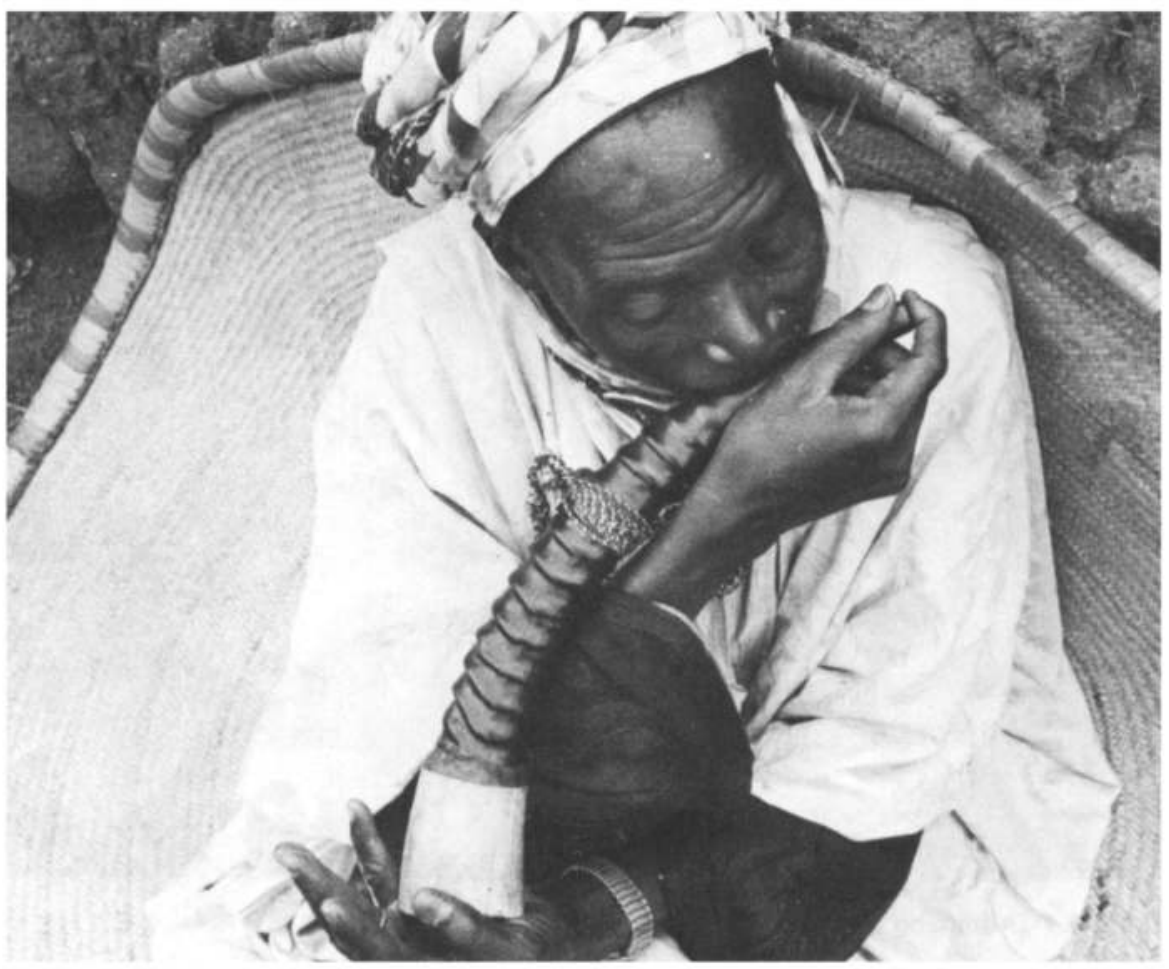

Figure 2. The head of the musicians at the court of the Emir of Zaria blowing the k'aho. 


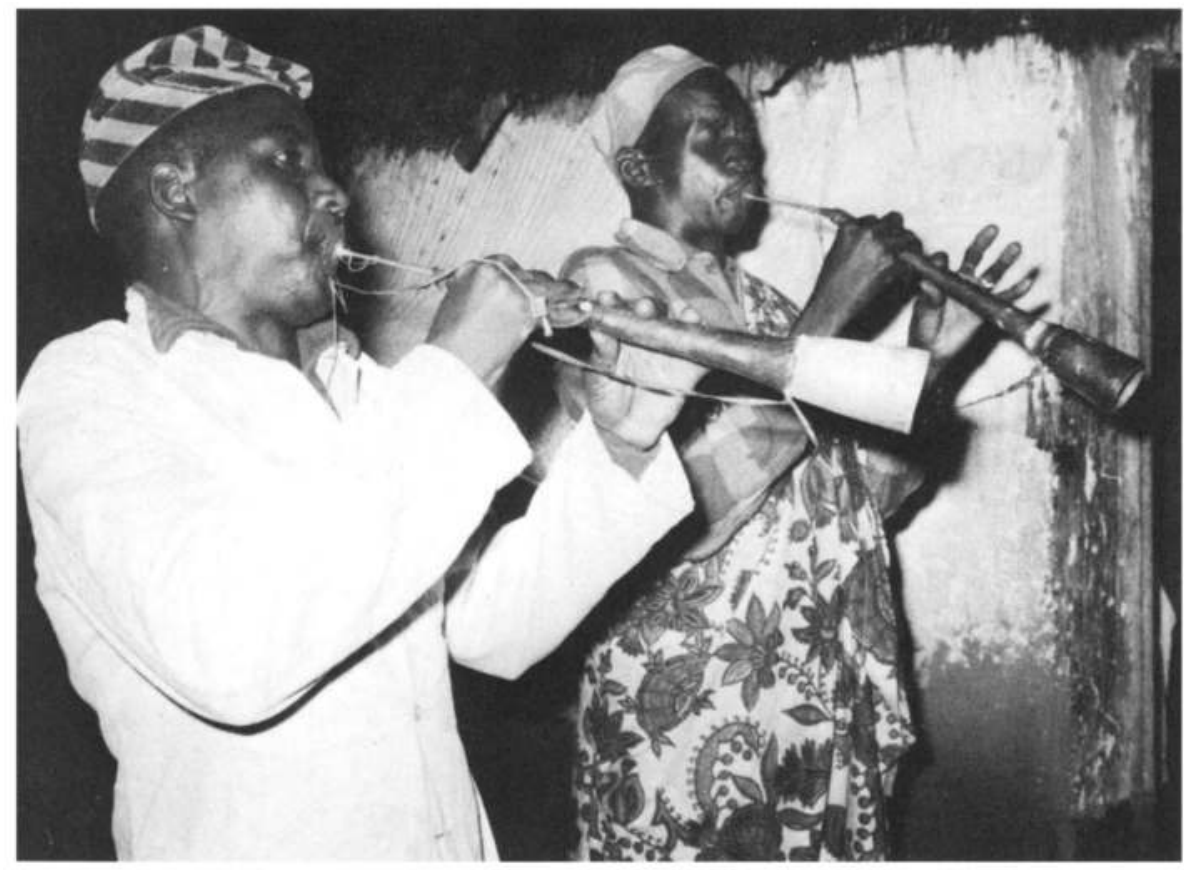

Figure 3. Musicians at the court of a district head in Zaria blowing algaitai for the Thursday night sara.

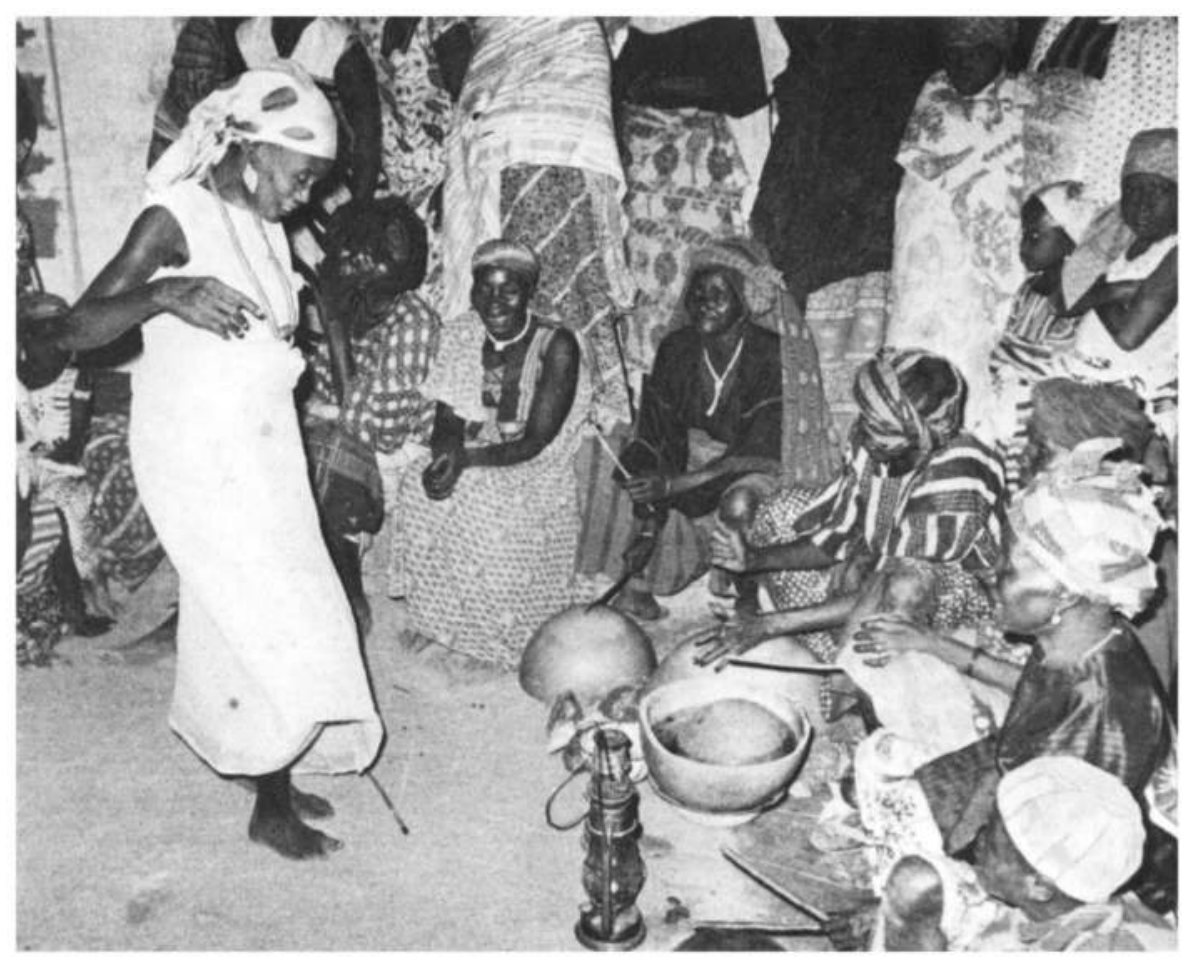

Figure 4. Drumming on calabashes ( $k^{\prime}$ warya) for bori dancing. 

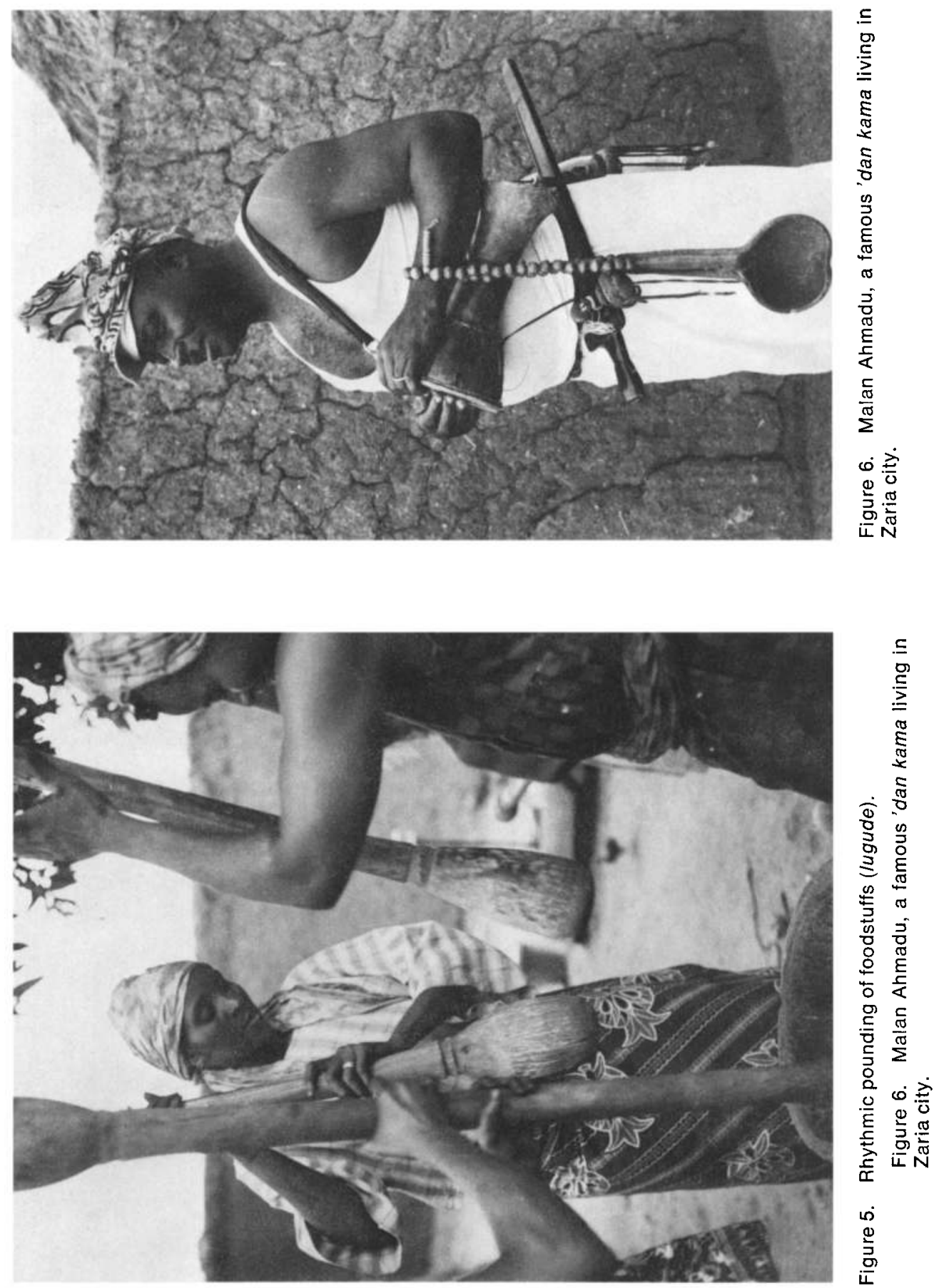


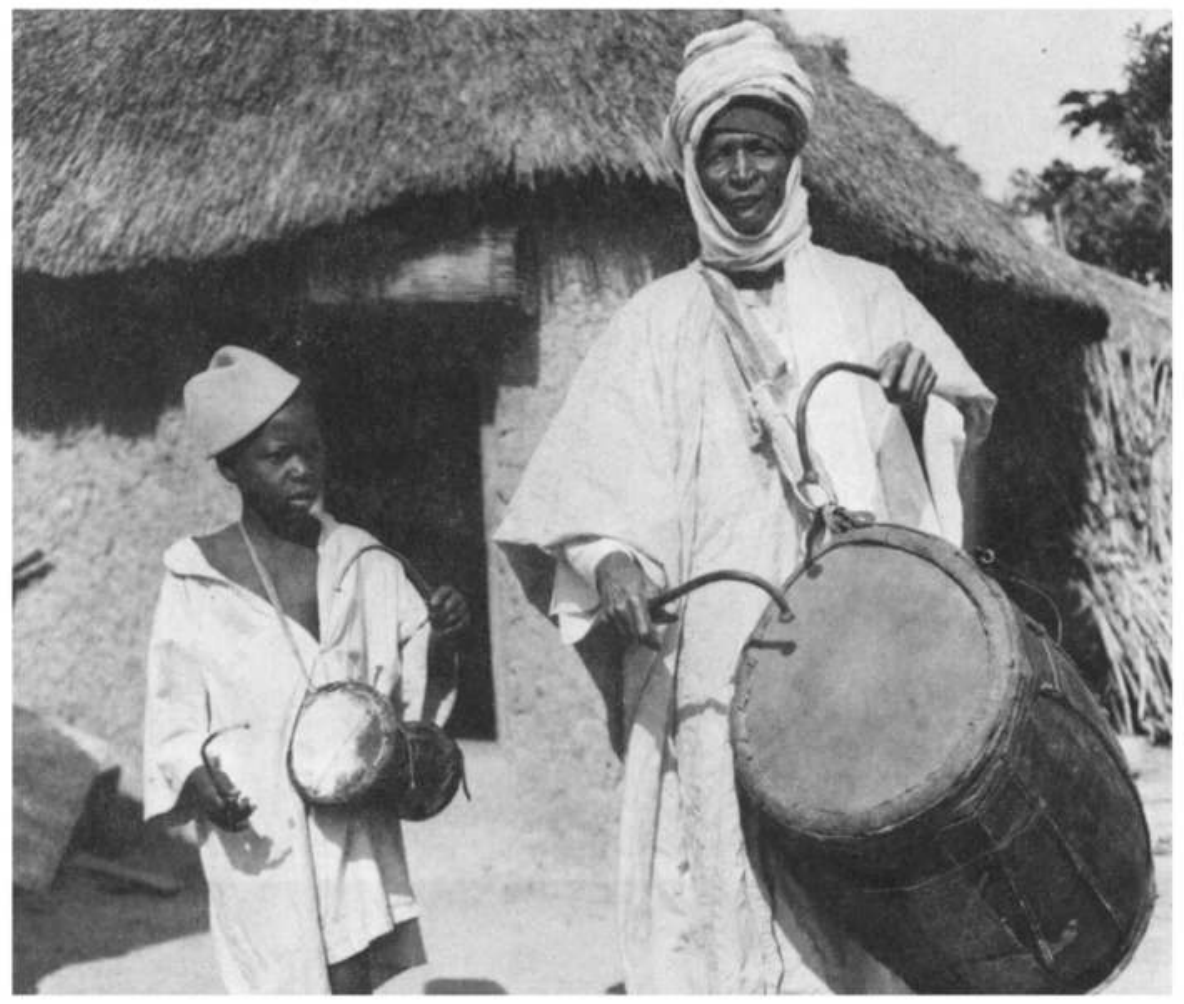

Figure 7. The chief of the drummers for farmers in the emirate of Zaria drumming on the gangan noma (right), and his son drumming on the kazagi (left).

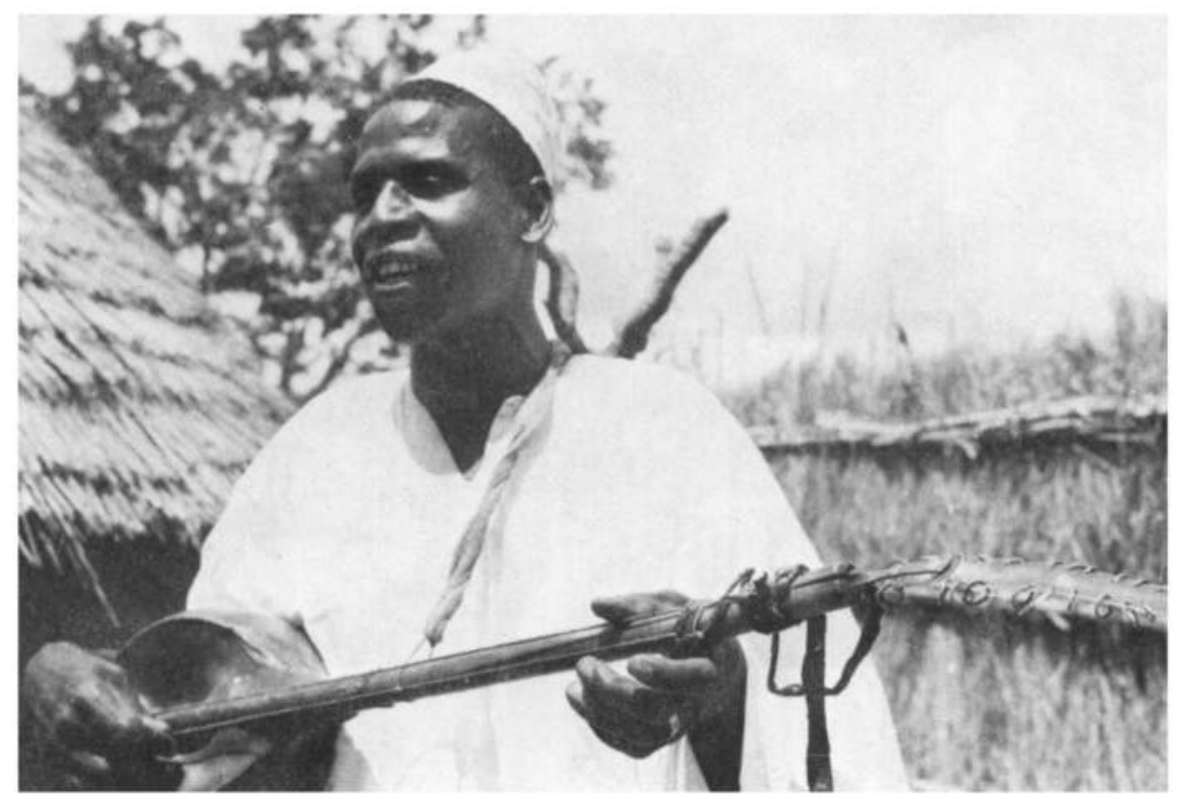

Figure 8. Mai komo accompanying his song of praise on the komo or babbar garaya. 


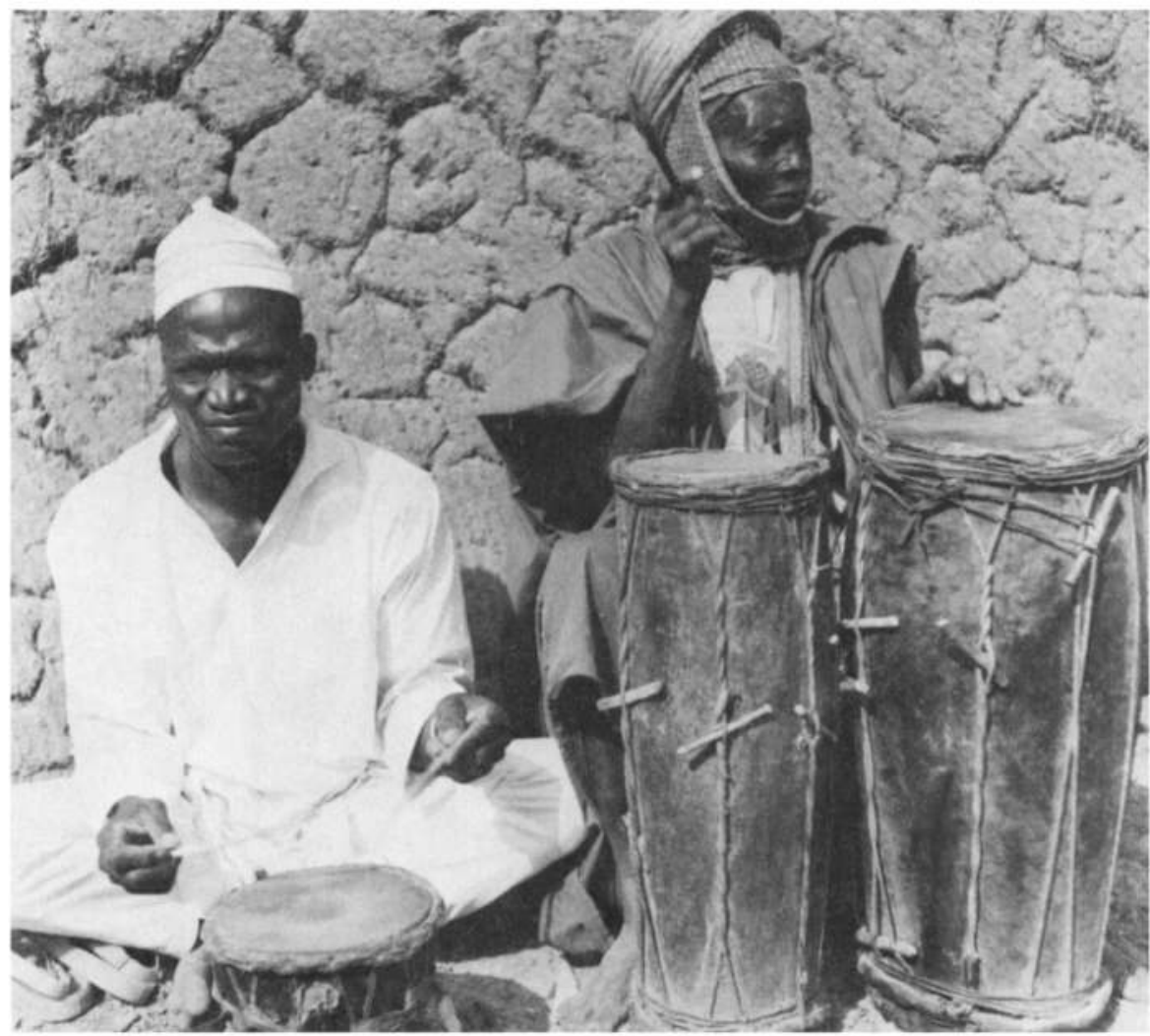

Figure 9. 'Yan dundufa drumming on dundufa and 'yar dundufa (right) and kuntuku (left) in honor of a blacksmith, their traditional patron.

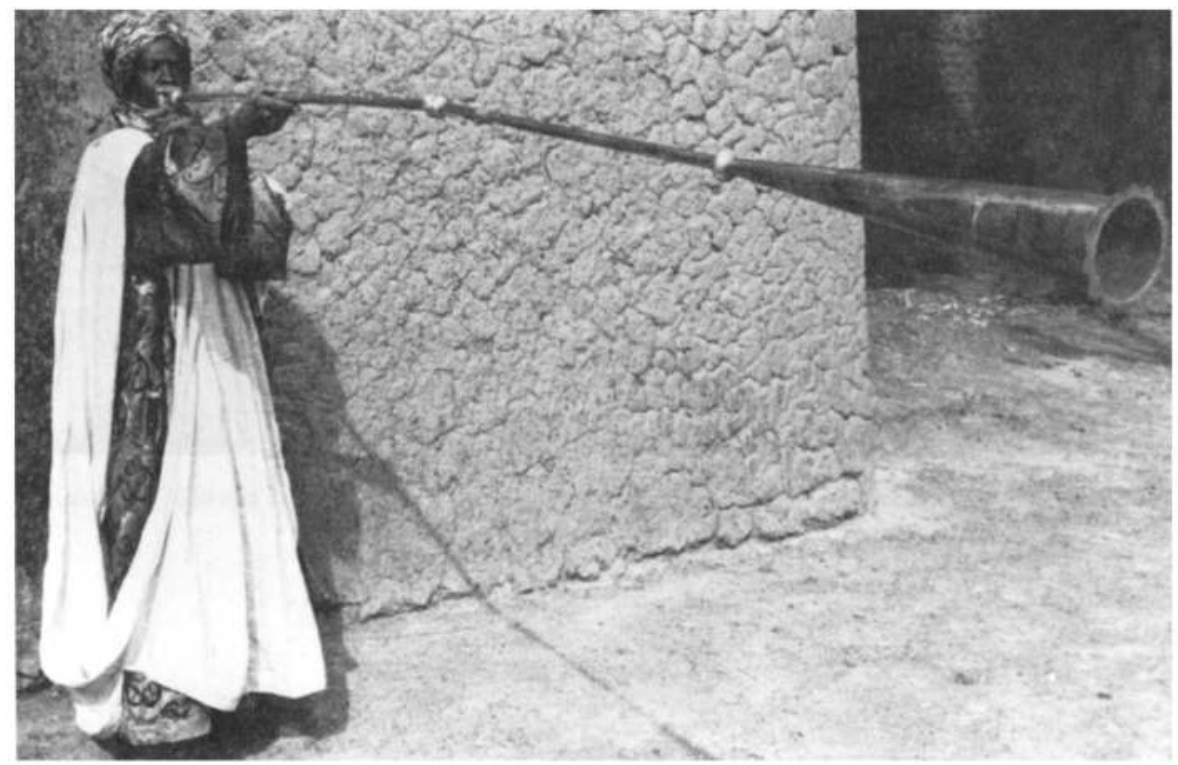

Figure 10. The Chief Trumpeter on kakaki for the Emir of Zaria. 


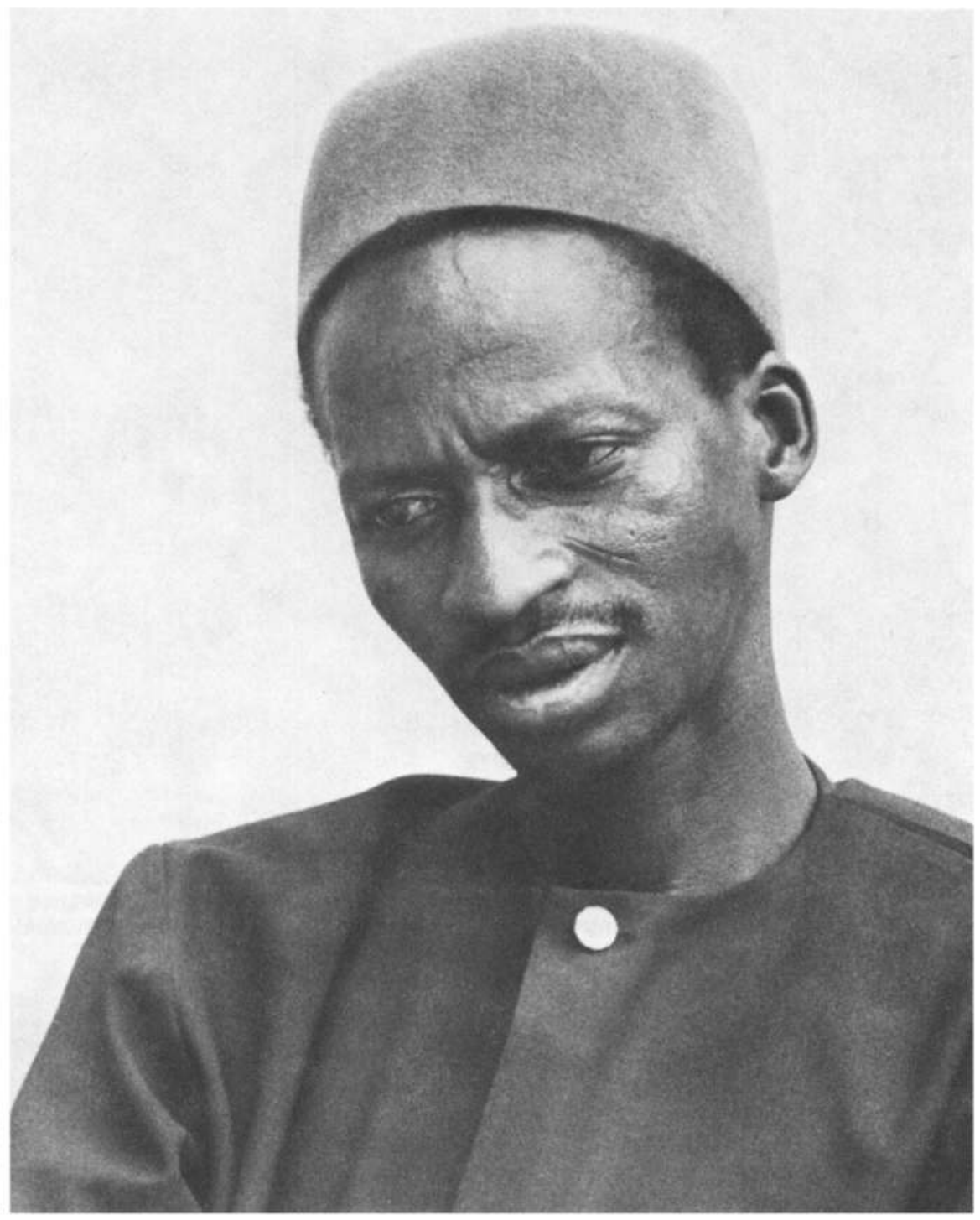

Figure 11. Alhaji Muhamman Shata. 


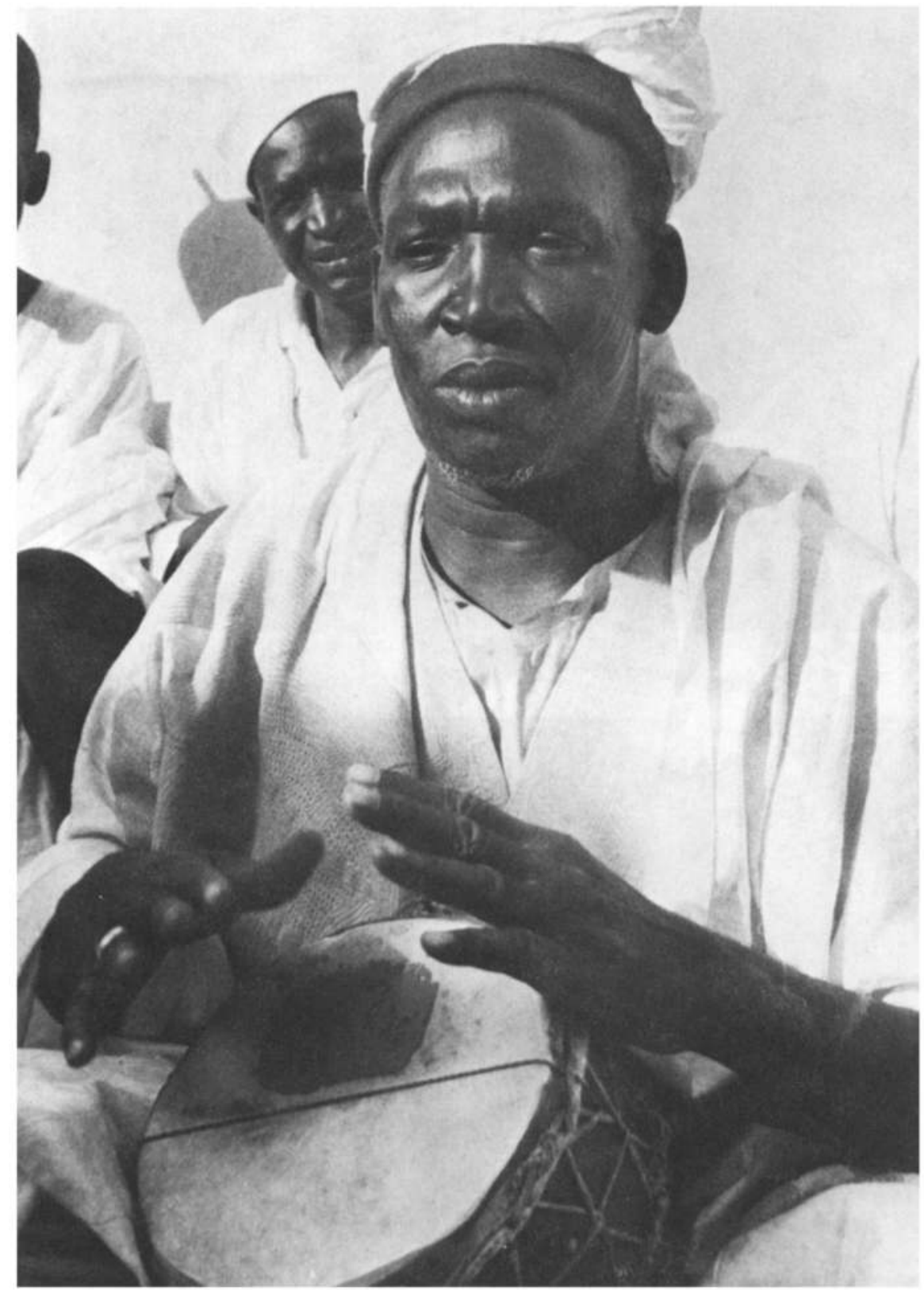

Figure 12. Sarkin Tabshi Alhaji Mamman. 


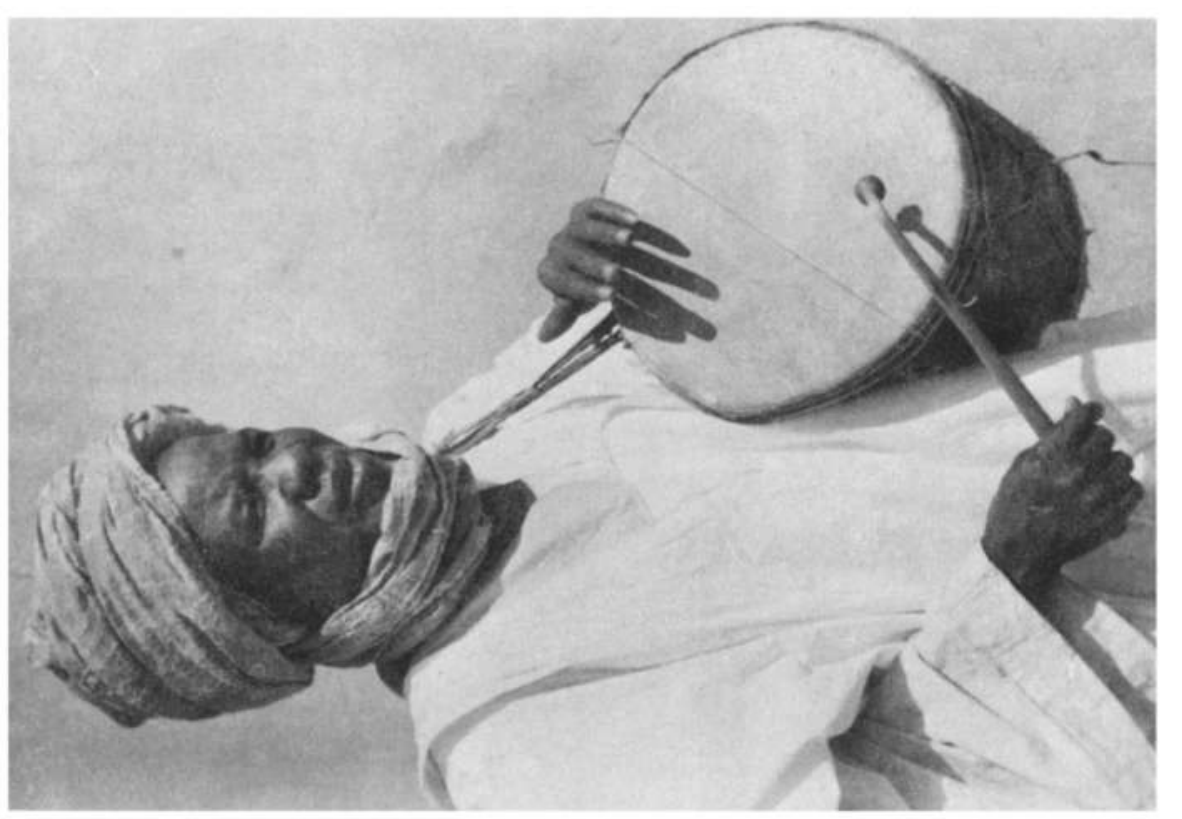

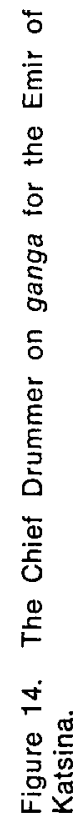

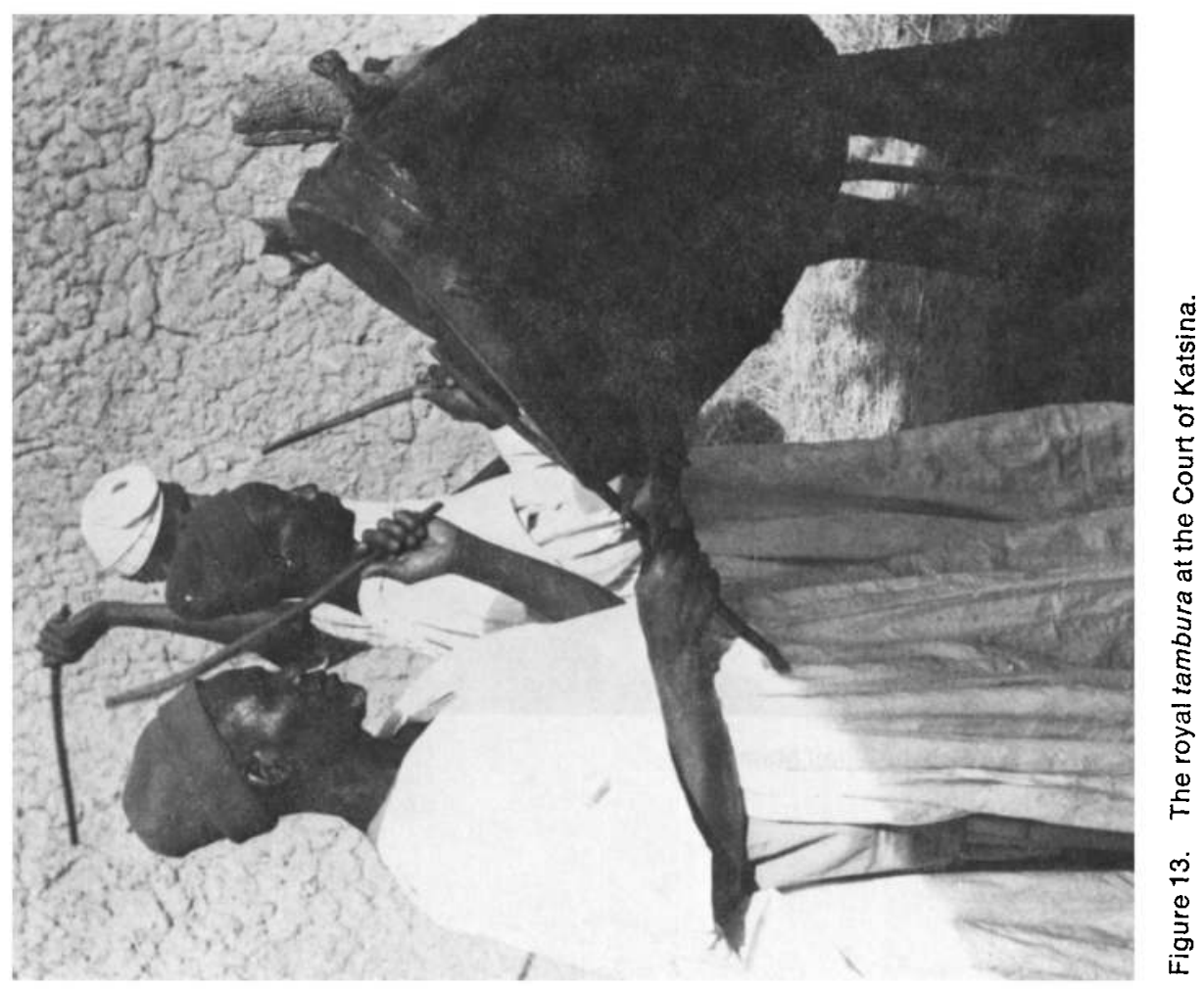



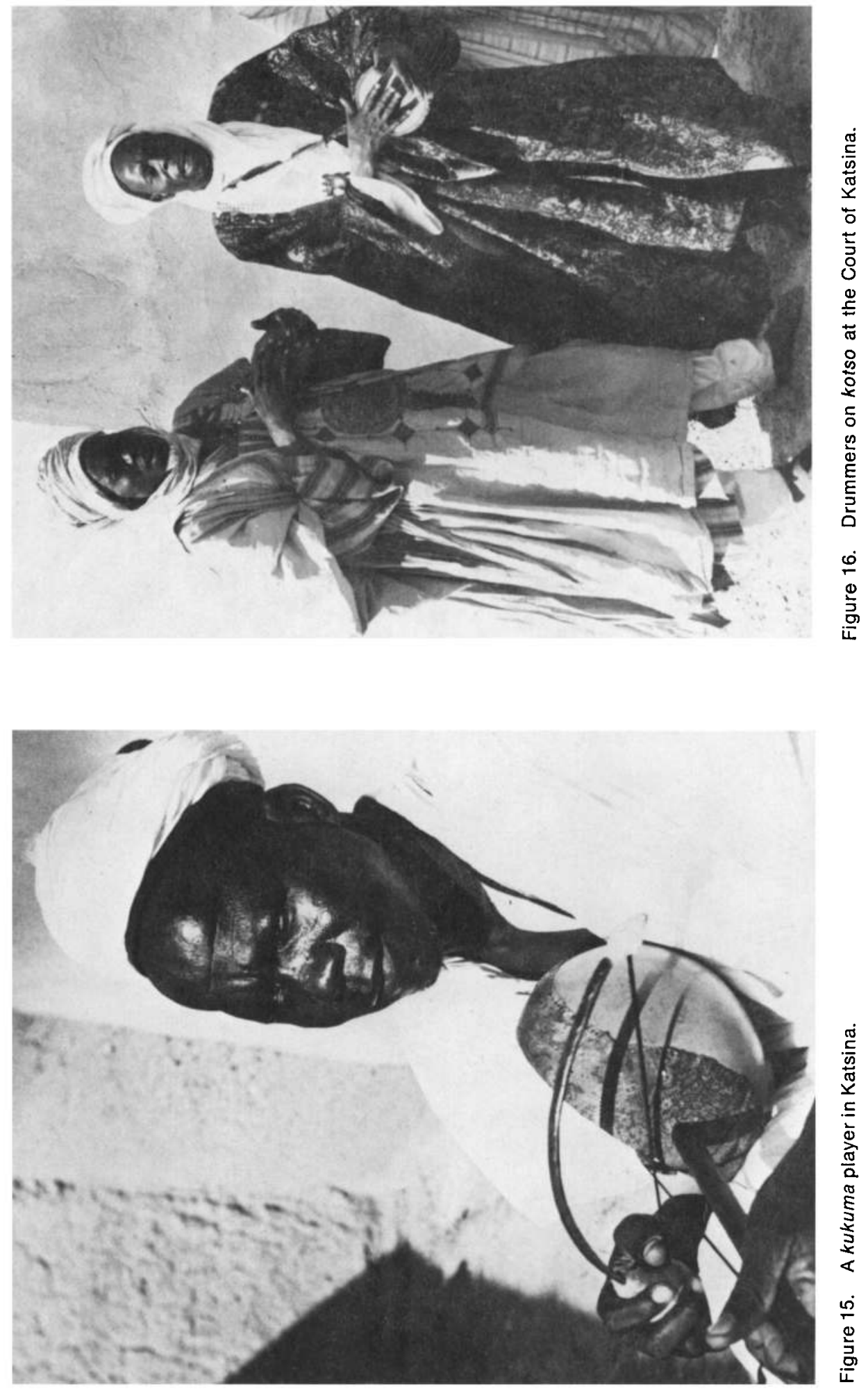
Figure 17. The head of the banga drummers at the Court of Katsina.
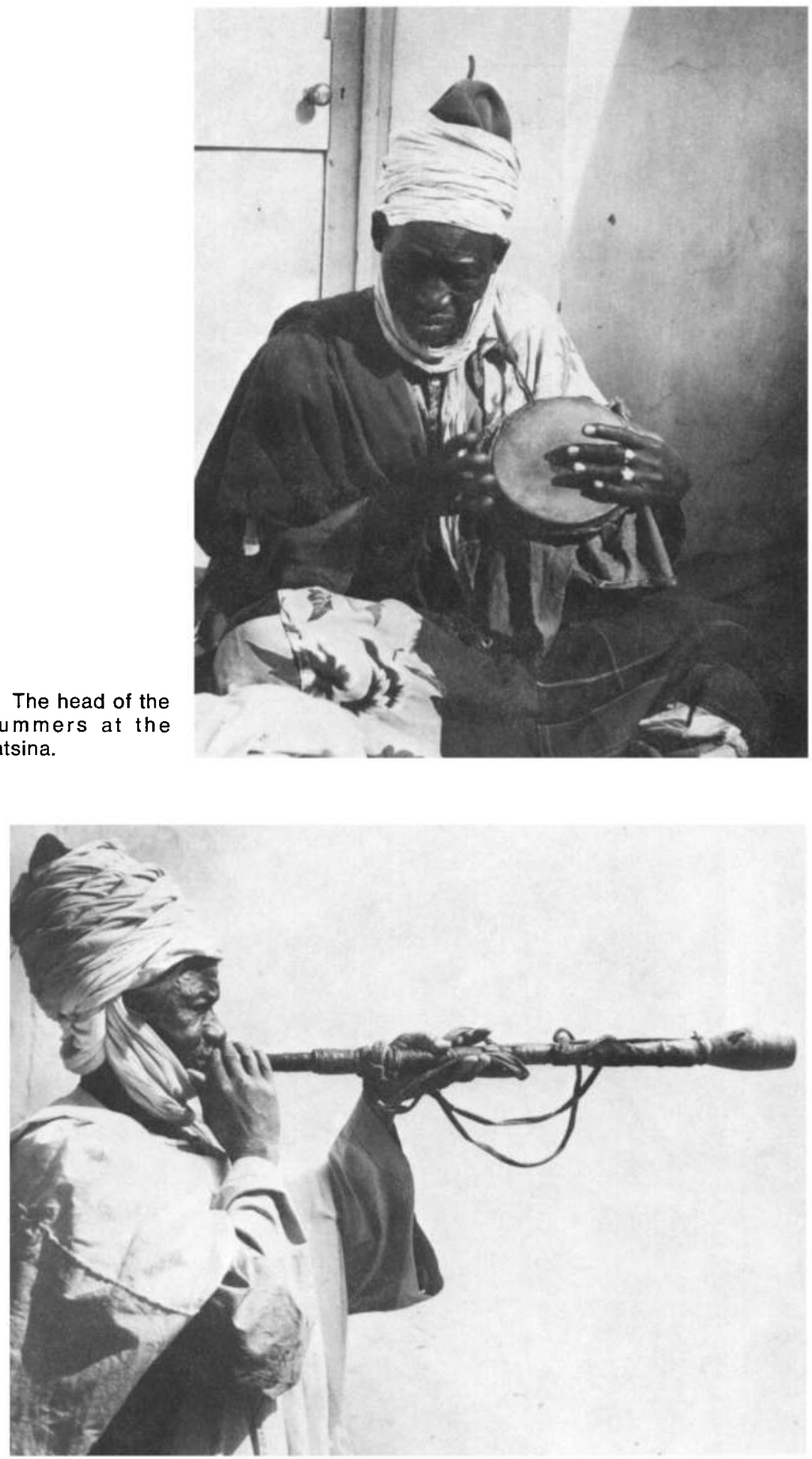

Figure 18. The head of the farai players at the Court of Katsina. 

